
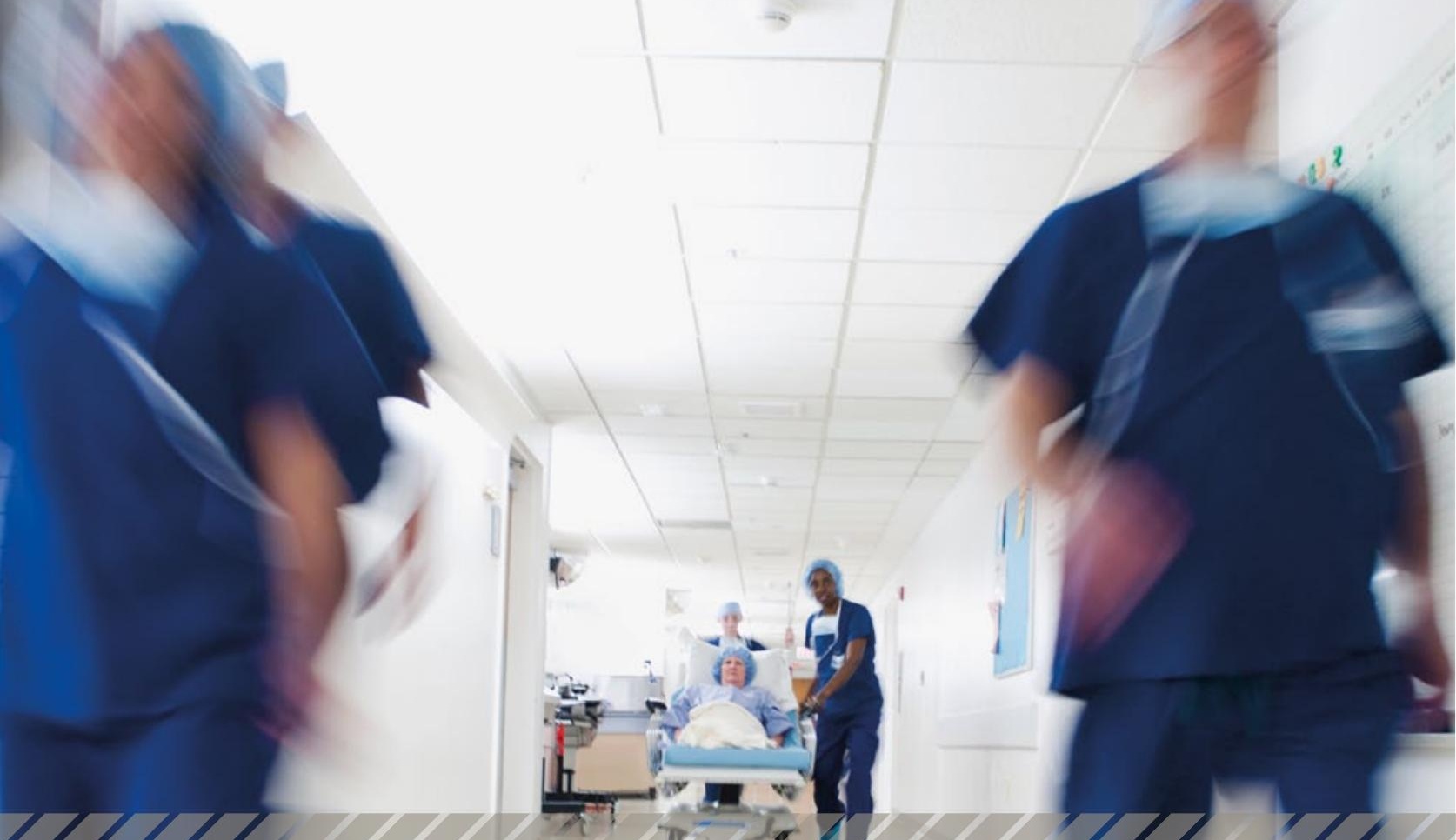

Syerke rerabey

Leren van patiéntenervaringen

voor goede zorg

Redactie: Stans van Egmond, Marjolijn Heerings en Geert Munnichs

Rathenau Instituut

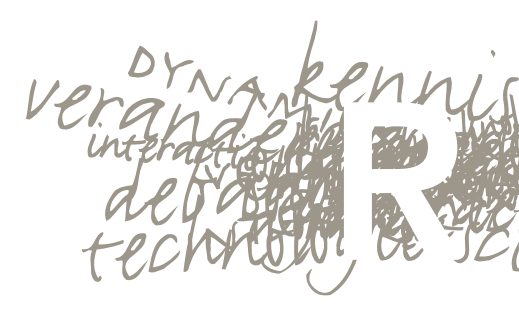


Het Rathenau Instituut stimuleert de publieke en politieke meningsvorming over wetenschap en technologie. Daartoe doet het instituut onderzoek naar de organisatie en ontwikkeling van het wetenschapssysteem, publiceert het over maatschappelijke effecten van nieuwe technologieën, en organiseert het debatten over vraagstukken en dilemma's op het gebied van wetenschap en technologie.

\section{Sterke verhalen uit het ziekenhuis}

Leren van patiëntenervaringen voor goede zorg 


\section{(c) Rathenau Instituut, Den Haag 2014}

Rathenau Instituut

Anna van Saksenlaan 51

Postadres:

Postbus 95366

2509 CJ Den Haag

Telefoon: 070-342 1542

Telefax: 070-363 3488

E-mail: info@rathenau.nl

Website: www.rathenau.n

Uitgever: Rathenau Instituut

Ontwerp en opmaak: Smidswater

Illustraties: Farida Laan

Foto's: Hollandse Hoogte

Drukwerk: Drukkerij Quantes, Rijswijk

Dit boek is gedrukt op FSC-gecertificeerd papier.

Eerste druk: Februari 2014

\section{ISBN/EAN: 978-90-77364-54-3}

Deze publicatie kan als volgt worden aangehaald:

Egmond, S. van, M. Heerings \& G. Munnichs, Sterke verhalen uit het ziekenhuis: Leren van patiëntenervaringen voor goede zorg. Den Haag: Rathenau Instituut, 2014

Het Rathenau Instituut heeft een Open Access beleid. Rapporten, achtergrondstudies, wetenschappelijke artikelen, software worden vrij beschikbaar gepubliceerd. Onderzoeksgegevens komen beschikbaar met inachtneming van wettelijke bepalingen en ethische normen voor onderzoek over rechten van derden, privacy, en auteursrecht.

\section{Sterke verhalen uit het ziekenhuis}

Leren van patiëntenervaringen

voor goede zorg

Redactie

Stans van Egmond

Marjolijn Heering

Geert Munnichs 
Bestuur van het Rathenau Instituut mw. G.A. Verbeet (voorzitter)

prof. dr. E.H.L. Aarts

prof. dr. ir. W.E. Bijker

prof. dr. R. Cools

dr. H. Dröge

drs. E.J.F.B. van Huis

prof. dr. H.W. Lintsen

prof. mr. J.E.J. Prins

prof. dr. M.C. van der Wende

mr. drs. J. Staman (secretaris)

\section{Voorwoord}

Patiënten zijn steeds mondiger geworden. Althans, dat is het beeld. We zijn hoger opgeleid en hebben dankzij internet meer toegang tot medische informatie. De overheid doet de laatste jaren een steeds groter beroep op de mondige patiënt in haar streven naar kwalitatief betere en betaalbare zorg op basis van marktwerking. Mondig zijn kan daarnaast om andere redenen belangrijk zijn. Patiënten vormen het hart van de zorg. Zij moeten leven met de consequenties van een ziekte of een behandeling. Bovendien gaan in de zorg miljarden euro's per jaar om, die mede door de patiënt betaald worden. Het ligt voor de hand dat patiënten daarin een stem hebben. Dit roept de vraag op hoe reëel het idee van die sterke en mondige ziekenhuispatiënt eigenlijk is? En of patiënten voldoende ruimte krijgen om mondig te zijn, om zelf beslissingen te nemen en invloed te hebben op de zorg in ziekenhuizen?

Dit onderzoek laat zien dat het voor patiënten niet altijd makkelijk is om hun stem te laten horen. Mensen zijn vaak helemaal niet zo mondig in het ziekenhuis. De onverwachte confrontatie met ziekte maakt dat mensen angstig zijn en niet altijd goed weten hoe zij zich op moeten stellen als patiënt en wat ze kunnen vragen of zeggen. Patiënten hebben bovendien een kennisachterstand ten opzichte van artsen. Ziekenhuizen zijn complexe, technologische organisaties die voor patiënten moeilijk te doorgronden zijn. Tegelijkertijd voelen veel patiënten een sterke behoefte om zelf regie te voeren over de zorg die zij krijgen. Bovendien ervaren patiënten dat zij deze regie ook moeten nemen. Zij willen of durven de verantwoordelijkheid voor de zorg niet alleen aan het ziekenhuis over te laten. Het blijkt vaak ook nodig om mondig te zijn in het ziekenhuis, om bijvoorbeeld fouten te voorkomen.

Patiënten en hun ervaringen vormen daarentegen een zeer rijke bron aan informatie over het functioneren van de zorg in het ziekenhuis. Patiënten zien zaken die niemand anders ziet. Hoewel we op beperkte schaal zien dat ziekenhuizen de stem en ervaring van patiënten serieuzer zijn gaan nemen - een aantal initiatieven staat beschreven in het intermezzo - moeten nog veel stappen worden gezet voordat de inbreng van patiënten echt serieus wordt meegenomen bij het vormgeven van de zorg. Met dit rapport wil het Rathenau Instituut bijdragen aan het versterken van de stem van de patiënt in de zorg en de discussie stimuleren over de manier waarop de inbreng van patiënten kan bijdragen aan de invulling van het begrip 'goede zorg'.

\section{Jan Staman}




\section{Inhoudsopgave}

\section{Voorwoord}

Samenvatting

Aanbevelingen

10

13

Deel I

(On)mogelijkheden tot mondigheid. Bevindingen en conclusies

\section{Roep om mondigheid}

Stans van Egmond, Marjolijn Heerings en Frans Brom

1.1 Inleiding

1.2 Leeswijzer

\section{Naar een mondige patiënt in de zorg}

Stans van Egmond en Marjolijn Heerings

2.1 Mondigheid in de spreekkamer: waarover gaat dat eigenlijk?

2.2 Marktwerking en de rol van de mondige patiënt

2.3 Meer zeggenschap en inspraak voor patiënten, maar waarover eigenlijk?

2.4 Het perspectief van de patiënt draagt bij aan goede kwaliteit van zorg

2.5 Hoe kan de patiënt het uitgangspunt worden voor ziekenhuiszorg? 29

2.6 Aanbevelingen

Intermezzo

Elf voorbeelden van initiatieven om ervaringen van patiënten

bruikbaar te maken voor kwaliteitsverbetering in ziekenhuizen

Deel II

Verhalen die bijdragen aan goede zorg

Stans van Egmond, Marjolijn Heerings, Anneke Sools,

Lisa van Duijvenbooden en Stans Drossaert

\section{Methoden}

3.1 Onderzoeksopzet

3.2 Onderzoeksmethode: De opzet van een narratieve analyse

3.3 Kennismaking met de schrijvers - wie deden er aan het onderzoek mee?
4 Ervaringen van patiënten en reacties hierop van zorgverleners

4.1 Negen archetypische ervaringen met ziekenhuiszorg

4.2 Workshops - ervaringen van zorgverleners met patiëntenervaringen 62

Inleiding tot de thema's: vormgeven aan kwaliteit van zorg,

autonomie en mondigheid

\section{9}

5 Onzekerheid of angst in een onbekende situatie

5.1 Patiëntenervaringen

Verhaal 1: De patiënt ervaart onzekerheid en wanhoop over het leven met een aandoening

Verhaal 2: De patiënt voelt zich gesteund door een beetje extra zorg

5.2 Onzekerheid, angst en wanhoop

5.3 Goede zorg is: aandacht voor wanhoop en angst

\section{Moeizame waardering van mondige en actieve patiënten}

6.1 Patiëntenervaringen

Verhaal 3: De patiënt is de bewaker van goede zorg

Verhaal 4: De patiënt of partner als co-professional

Verhaal 5: De patiënt ziet fouten in het systeem en raakt verontrust

6.2 Dunne lijn tussen mondig en lastig

6.3 Spanning tussen de meedenkende patiënt en het artsenperspectief 82

6.4 Goede zorg is: ruimte laten voor de eigen inbreng van de patiënt 84

7 Onmondig in het ziekenhuissysteem

7.1 Patiëntenervaringen

Verhaal 6: De patiënt is niet geïnformeerd en onmondig bij een onprettige behandeling

Verhaal 7: De patiënt of partner is onmachtig in een (falend) zorgproces

7.2 Onmondigheid

7.3 De rol van het ziekenhuissysteem bij onmondigheid

7.4 Goede zorg is: goed luisteren, goed informeren en de partner serieus nemen
70

70

71

76

77

79

80
82 
8 Onbekende verwachtingen - bij patiënt én zorgverlener

8.1 Patiëntenervaringen

Verhaal 8: De patiënt voelt zich in de steek gelaten door gebrek
aan goede zorg

Verhaal 9: De patiënt heeft een goede ervaring ondanks lage verwachtingen

8.2 Wat verwachten patiënten van het ziekenhuis?

8.3 Spanning tussen verschillende verwachtingen van zorgverleners en patiënten

8.4 Goede zorg is: realistische verwachtingen creëren

9 Conclusie

9.1 De mondige patiënt komt moeilijk tot zijn recht in het ziekenhuis $\quad 102$

$\begin{array}{ll}\text { 9.1 De mondige patient komt moeilijk tot zijn recht in het ziekenhuis } & 102 \\ & 103\end{array}$

9.3 Patiëntenervaringen geven veel informatie over de kwaliteit van ziekenhuiszorg

Literatuurlijst

Dankwoord

Over de auteurs

111

Interviews 


\section{Samenvatting}

De mondige patiënt: wens of werkelijkheid?

Patiënten zijn de laatste jaren mondiger geworden. Dat is althans het beeld dat vaak in het overheidsbeleid en in media wordt neergezet. We hebben dankzij internet immers meer informatie tot onze beschikking. We zijn hoger opgeleid en individualistischer geworden dan veertig jaar geleden. Dat leidt tot de gedachte dat we ook mondiger zijn geworden in situaties van ziekte en zorg: dat we beter weerwoord geven aan artsen, meer weten over ziekten en beter meedenken over de behandeling.

De overheid doet een steeds groter beroep op de mondige patiënt. Dat wordt vooral ingegeven door verandering in het beleid naar marktwerking in de zorg. De overheid zet in op mondigheid van patiënten vanuit de opvatting dat vraaggestuurde zorg en kwaliteitsverbetering in de zorg niet mogelijk zijn zonder de inbreng en inzichten van de patiënt. Mondigheid is hierbij een voorwaarde voor een goed werkend zorgsysteem en goede kwaliteit van zorg

Tegelijkertijd klinkt er kritiek op het beroep dat de overheid doet op de mondige patiënt. Belangengroepen voor patiënten zien deze patiënt niet terug in de zorgpraktijk. Patiënten zijn in hun ogen juist niet mondig genoeg en behoeven ondersteuning om een meer gelijkwaardige partner te kunnen worden van zorgverleners, zorgaanbieders en zorgverzekeraars. Medische beroepsgroepen zijn daarentegen ook eerder terughoudend als het gaat om het beroep op de mondige patiënt. De vraag is immers over welke aspecten van zorg patiënten mondig kunnen en moeten zijn.

In de dagelijkse praktijk van het ziekenhuis lijkt het beroep van de overheid op de mondige patiënt nog maar moeizaam vorm te krijgen. Ziekenhuizen zijn complexe, technologische en hiërarchische organisaties. Bij de zorg voor patiënten zijn meerdere zorgverleners, specialisaties en soms zelfs meerdere ziekenhuizen betrokken. Daarbij zijn protocollen en evidence based-richtlijnen leidend. Patiënten doorzien die structuur niet voldoende, hebben een kennisachterstand ten opzichte van de arts, en zijn door hun ziekte ook afhankelijk van artsen en verpleegkundigen. Deze en bovengenoemde ontwikkelingen roepen de vraag op: hoe reëel is de gedachte van een mondige patiënt in werkelijkheid?

Het doel van dit onderzoek is via geschreven ervaringen van patiënten met ziekenhuiszorg inzicht te krijgen in de rol van de mondige patiënt in het ziekenhuis, en in de bijdrage die ervaringen van patiënten kunnen leveren aan verbetering van de kwaliteit van de zorg.
Hoe mondig is de patiënt?

Voor ons onderzoek hebben we gebruikgemaakt van geschreven verhalen van patiënten en naasten met ziekenhuiszorg, workshops met zorgverleners over deze ervaringen en interviews met stakeholders uit de ziekenhuiswereld. Ons onderzoek laat zien dat mensen vaak minder mondig zijn dan zij zouden willen of dan noodzakelijk of wenselijk is. De analyse van de verhalen en andere onderdelen van het onderzoek brengt vier thema's zichtbaar die een rol spelen bij deze onmondigheid:

\section{Onzekerheid of angst in een onbekende situatie}

Door ziekte, een aandoening of acute opname voelen mensen zich onzeker, angstig of wanhopig. Dat kan worden veroorzaakt door pijn, angst voor (mogelijk) overlijden, fysieke aftakeling of het onbekende vooruitzicht te moeten leven met een ziekte. In veel verhalen zijn mensen eerst bezig te leren omgaan met de onzekerheid en angst die een diagnose of ziekenhuisverblijf met zich mee-

brengt. Pas daarna hebben ze oor en oog voor andere zaken in het ziekenhuis.

\section{Moeizame waardering van mondige en actieve patiënten}

Veel patiënten of hun naasten stellen zich actief op in hun eigen ziekte en de zorg in het ziekenhuis. Dat doen zij om verschillende redenen: soms zijn ze ervaringsdeskundigen die veel weten van hun eigen lichaam en ziekte, soms voelen ze zich vrijwillig medeverantwoordelijk voor goede zorg. Anderen voelen zich gedwongen als bewaker van goede zorg op te treden doordat ze dingen mis zien gaan. Deze actieve houding wordt niet altijd gewaardeerd of begrepen door zorgverleners en kan er zelfs toe leiden dat patiënten als 'lastig' worden weggezet.

\section{Onmondig in het ziekenhuissysteem}

Veel mensen, zowel patiënten als naasten, voelen zich onmondig in het ziekenhuis, ook als ze in het dagelijks leven mondig genoeg zijn. De organisatie van zorg in het ziekenhuis en de houding van sommige zorgprofessionals dragen hieraan bij. Mensen vinden dat ze slecht worden geïnformeerd over procedures, diagnoses of behandelingen. Ze ervaren ook dat artsen en verpleegkundigen weinig tijd hebben voor en empathie hebben met hun emoties en gevoelens. In sommige verhalen worden klagende patiënten genegeerd door zorgverleners. Patiënten houden klachten of onvrede daarom vaak voor zich, om niet te worden gezien als een lastig persoon.

\section{Onbekende verwachtingen - bij patiënten én zorgverleners}

De verwachtingen van patiënten sluiten vaak niet aan bij dat wat het ziekenhuis te bieden heeft. Mensen weten niet wat ze kunnen verwachten of hebben juist lage of (te) hoge verwachtingen van de zorg in het ziekenhuis. Tegelijkertijd hebben zorgprofessionals bepaalde, vaak impliciete, verwachtingen van patiënten. Het komt regelmatig voor dat de verwachtingen van patiënten niet overeenkomen met die van de zorgverleners. Dat kan bijdragen aan onverwacht positieve, maar vaker juist negatieve ervaringen van patiënten. 
Een verblijf in het ziekenhuis is voor mensen geen neutrale ervaring en roept sterke gevoelens op. Het gaat immers om ziekte, gezondheid, onzekerheid en onwetendheid. Zowel bij de patiënt zelf als in de organisatie van de ziekenhuiszorg staan voornoemde obstakels de ontwikkeling naar een mondige, gehoorde patiënt in de weg. Patiënten voelen vaak een sterke behoefte aan regie over he eigen zorgproces, maar het ziekenhuis voorziet hierin niet altijd goed. Dat levert spanning op in de contacten tussen enerzijds patiënten en hun naasten en anderzijds zorgverleners. Sterker: kritische, meedenkende patiënten lopen vaak het risico dat zij worden weggezet als lastig en veeleisend, waardoor ze een tekort aan zorg krijgen. En het leidt ertoe dat mensen in de praktijk van het ziekenhuis vaak minder mondig zijn en worden ze minder goed gehoord dan gewenst is. Ons onderzoek laat zien dat het beeld van de mondige patiënt bijstelling behoeft.

\section{Patiënten hebben inzicht in goede kwaliteit van zorg en} dragen er aan bij

Tegelijkertijd blijkt uit het onderzoek dat patiënten wel degelijk een goede bron van informatie zijn als het gaat om de betekenis van goede kwaliteit van zorg, de betekenis van 'patiëntgerichtheid' van zorg en de relationele aspecten van zorg. Goede zorg betekent voor patiënten: aandacht krijgen voor de wanhoop en angst waarmee een plotselinge ziekte of opname vaak gepaard gaat; dat zorgprofessionals patiënten serieus nemen en goed luisteren naar wat zij zeggen over hun fysieke toestand en dat vervolgens onderzoeken; dat er goede en tijdige informatie is over de situatie, de diagnose, testen, de behandeling en het verblijf in het ziekenhuis. Goede zorg houdt daarnaast in dat de partner of vertegenwoordiger van de patiënt serieus wordt genomen als gesprekspartner. En dat er zorg wordt gedragen voor een goede organisatie van de processen - zoals het op orde zijn van dossiers, het juist toedienen van de juiste medicijnen en het niet onnodig rekken van het ziekenhuisverblijf - en dat daarbij wordt geluisterd naar patiënten.

\section{Noodzaak tot inzetten stem van de patiënt}

De (internationale) politieke druk op ziekenhuizen neemt toe om patiëntenervaringen in te zetten ter verbetering van de kwaliteit en de organisatie van zorg. De algemene aanname is dat beter luisteren naar patiënten en patiëntgerichter werken de kwaliteit en veiligheid van zorg verbetert, ongeacht de ideologische insteek. Ons onderzoek onderschrijft dit, maar laat ook zien dat het patiënten niet altijd makkelijk wordt gemaakt een actieve inbreng te hebben in de zorg. Het welzijn van de patiënt is meer gebaat bij ziekenhuizen die de patiënt ruimte geven voor een actieve inbreng, dan bij een verdere juridisering van klachten. Patiëntenervaringen bieden goede aanknopingspunten daarvoor. In het kader van dit onderzoek zijn enkele initiatieven in ziekenhuizen in kaart gebracht die laten zien hoe patiënten als gesprekspartner serieus genomen kunnen worden en hoe dat een meerwaarde oplevert bij het verbeteren van de zorg.

\section{Aanbevelingen}

In de ziekenhuiszorg wordt steeds meer uitgegaan van de mondige patiënt die een actieve inbreng in het eigen zorgproces heeft. Toch kan in ziekenhuizen nog een flinke slag gemaakt worden om deze patiëntgerichtheid te ondersteunen. De zorg wint aanzienlijk aan kwaliteit als binnen het zorgproces meer structurele aandacht uitgaat naar de wensen en behoeften van patiënten. Dat vergt een andere inrichting van het zorgproces, bijvoorbeeld door gebruikt te maken van (positieve en negatieve) verhalende ervaringen van patiënten als vast onderdeel van de kwaliteitszorg van ziekenhuizen.

Om patiëntgerichte zorg te versterken doen we de volgende aanbevelingen aan ziekenhuizen en zorgverzekeraars:

- Ziekenhuizen kunnen hun organisatorisch leervermogen vergroten door structureel gebruik te maken van positieve én negatieve verhalende patiëntenervaringen.

- Ziekenhuizen kunnen de luistervaardigheden van zorgverleners in het ziekenhuis verbeteren door het inzetten van instrumenten zoals beschreven in dit onderzoek, bijvoorbeeld de Elst Borst-gesprekken een patiëntluisteraar of een ander instrument.

- Zorgverzekeraars kunnen een rol spelen in het verwezenlijken van beide aanbevelingen door financiering van dergelijke projecten of via contractafspraken met ziekenhuizen.

- Voor het sturen van verwachtingen van patiënten is het van belang dat ziekenhuizen duidelijk maken wat patiënten van het ziekenhuis kunnen verwachten en wat niet, bijvoorbeeld door deze informatie te integreren in bestaande communicatiemiddelen zoals de website, sociale media, folders, het opnamegesprek en het ontslaggesprek.

- Voor het versterken van patiëntgerichte zorg kunnen ziekenhuizen en zorgverzekeraars de volgende instrumenten inzetten:

1. Maak gebruik van verschillende methoden die ingezet kunnen worden voor kwaliteitsverbetering, bijvoorbeeld beschreven in het intermezzo in dit boek, zoals de verhalen van patiëntenervaringen.

2. Zet de klachtenfunctionaris in, zoals omschreven in het wetsvoorstel WKKGZ. Deze kan, naast klachten en onvrede, ambivalente en positieve ervaringen opnemen ter verbetering van kwaliteit van zorg.

3. Neem het leren van ervaringen op in de criteria voor klachtenprocedures.

4. Stel patiënten actief op de hoogte over de mogelijkheid ervaringen te delen, en stel ze, door middel van bestaande communicatiemiddelen, steeds op de hoogte tot welke verbeteringen in de zorg dit heeft geleid. 


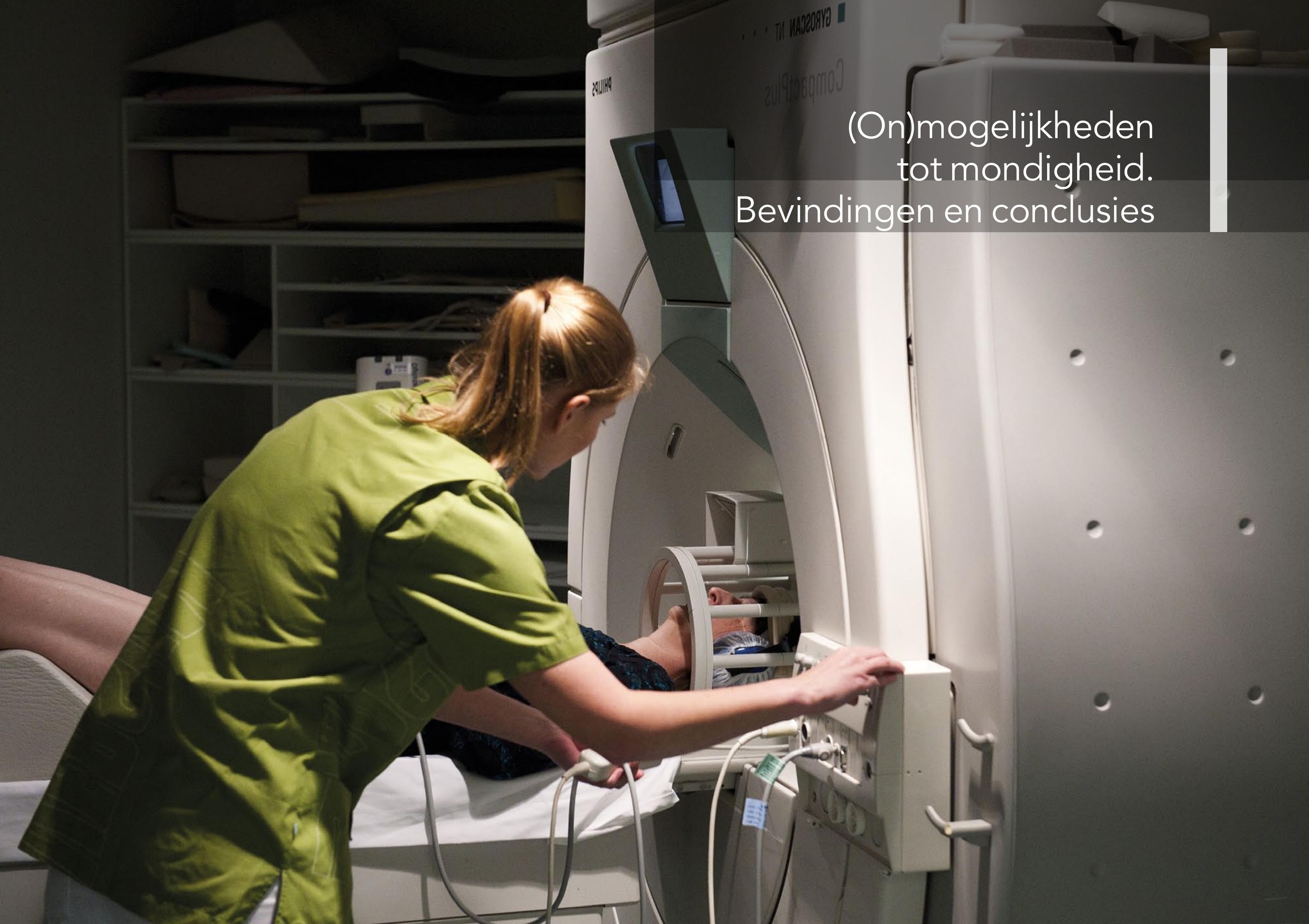




\section{Roep om mondigheid}

Auteurs:

Stans van Egmond, Marjolijn Heerings, Frans Brom

\subsection{Inleiding}

Patiënten zijn de laatste jaren mondiger geworden. Dat is althans het beeld dat vaak in overheidsstukken en in media wordt neergezet. We hebben dankzij internet immers meer informatie tot onze beschikking. We zijn hoger opgeleid en individualistischer geworden dan veertig jaar geleden. Dat leidt impliciet tot de gedachte dat we ook mondiger zijn geworden in situaties van ziekte en zorg: dat we beter weerwoord kunnen geven aan artsen en meer weten over ziekten, behandelingen. En dat we meer regie en zeggenschap willen en kunnen hebben over de kwaliteit van het eigen leven en de kwaliteit van de zorg.

De overheid doet een steeds groter beroep op deze mondige patiënt, onder meer ingegeven door de in 2006 ingevoerde Wet Marktwerking Gezondheidszorg. Deze wet gaat immers uit van een kritische en mondige patiënt, wiens stem in het zorgstelsel genoeg macht heeft om tegenwicht te bieden aan zorgaanbieders en zorgverzekeraars. Om de positie van de patiënt op dit gebied verder te versterken werkt de overheid sinds 2008 aan een reeks wetten (tot voor kort onder de noemer wetsvoorstel Cliëntenrechten Zorg). Doel hiervan is de kwaliteit van de zorg te verbeteren en de kosten te verlagen door meer gebruik te maken van de eigen ervaringsdeskundigheid van de patiënt en door de zorg meer te organiseren rondom diens vraag en wensen. Daarvoor zijn mondige patiënten nodig.

Maar ook uit andere hoeken klinkt de roep om een mondiger patiënt. Zorg gaat nog onvoldoende uit van de behoefte van patiënten en dat moet beter kunnen, zo staat in het rapport De participerende patiënt van de Raad voor de Volksgezondheid \& Zorg (RVZ) uit 2013. Daarnaast stellen ook twee internationaal vermaarde rapporten uit 2013 over het functioneren van Britse ziekenhuizen dat zorg meer moet uitgaan van wensen van de patiënt, en dat de ervaring van de patiënt in elke laag van de organisatie van ziekenhuizen meegenomen moet worden om de kwaliteit van de zorg te verbeteren. Deze ontwikkelingen leggen een grotere druk op ziekenhuizen om de ervaringen van patiënten als uitgangspunt te nemen voor een betere organisatie van zorgprocessen, en voor het inzichtelijk maken en verbeteren van de kwaliteit en de veiligheid van ziekenhuiszorg.

\section{Felle discussies over de mondige patiën}

Over de precieze vorm en de onderliggende rechtvaardiging voor het versterken van de positie van patiënten bestaat geen politieke overeenstemming. Net zomin als er overeenstemming bestaat over de aspecten van zorg waarover patiënten mondig kunnen en moeten zijn. Dit wordt zichtbaar in felle discussies in het parlement en daarbuiten en dat blijkt ook uit de vele moties op het wetsvoorstel Cliëntenrechten zorg.

Vanuit verschillende belangengroepen klinkt kritiek op het beroep dat de overheid doet op de mondige patiënt. Patiëntenorganisaties zien deze mondige patiënt niet terug in de zorgpraktijk. Zij stellen dat patiënten juist niet mondig genoeg zijn en zich vaak afhankelijk opstellen van zorgverleners. Patiënten

behoeven ondersteuning om in meerdere opzichten een gelijkwaardiger partner te zijn ten opzichte van zorgverleners, zorgaanbieders en zorgverzekeraars. Patiëntenorganisaties werken hier al jaren hard aan, vooral voor mensen met een chronische aandoening.

In de medische wereld wordt het nut van het inzetten van patiëntenervaringen gezien, maar is men nog terughoudend. Gert van Dijk van de Koninklijke Nederlandsche Maatschappij tot bevordering der Geneeskunst (KNMG) stelt: "Patiënten zien weliswaar hoe ze behandeld worden, hoe laagdrempelig de zorg is en of het ziekenhuis klantvriendelijk is. Maar of de kwaliteit van zorg goed is, is als patiënt moeilijk te zien" (interview KNMG, 19-03-2013). De Orde van Medisch Specialisten (OMS) beaamt dit: "Patiënttevredenheid is een aspect van kwaliteit, maar niet het enige. Effectiviteit van de behandeling is voor medisch specialisten ook een belangrijk aspect van kwaliteit. Met het verzamelen van medisch inhoudelijke data wordt immers ook verbeterinformatie gegenereerd" (interview OMS, 21-05-2013).

Ziekenhuizen zijn de afgelopen decennia steeds complexer geworden. De inzet van technologie, het ontstaan van de superspecialist en het toenemende gebruik van protocollen en evidence based-richtlijnen zorgen ervoor dat de zorg voor de patiënt steeds verder gefragmenteerd raakt en zakelijker wordt. Deze spreiding van zorg vereist een goede integratie en overdracht van informatie en een goede samenwerking tussen verschillende disciplines en afdelingen. Dat gaat niet altijd even makkelijk en maakt ziekenhuizen weinig transparant voor patiënten. Patiënten hebben bovendien een enorme kennisachterstand ten opzichte van artsen en zijn door hun ziekte afhankelijk van de arts. Het is daarom misschien niet vreemd dat uit onderzoek naar arts-patiëntrelaties blijkt dat de mondigheid van patiënten in de spreekkamer de afgelopen vijftien jaar is afgenomen (Bensing e.a. 2006). 


\section{Voldoende bestaansrecht voor de mondige patiënt?}

Deze maatschappelijke, politieke en technologische ontwikkelingen roepen vragen op over de mondigheid van patiënten: krijgen patiënten voldoende ruimte om zelf beslissingen te nemen en invloed te hebben op de zorg in ziekenhuizen? Hoe reëel is het idee van een sterke en mondige ziekenhuispatiënt eigenlijk? Het Rathenau Instituut onderzoekt deze kwesties. De centrale vragen van deze studie zijn:

1. Hoe ervaren patiënten en hun naasten de aan hen verleende ziekenhuiszorg? 2. Wat zeggen deze ervaringen over de rol van de mondige patiënt in het zorgproces?

3. Hoe kunnen deze ervaringen bijdragen aan het verbeteren van de kwaliteit van de ziekenhuiszorg?

We hebben deze vragen onderzocht via een aantal kwalitatieve methoden Allereerst hebben we geschreven ervaringen van patiënten over hun verblijf in het ziekenhuis verzameld en geanalyseerd om te onderzoeken hoe mensen ziekenhuiszorg ervaren. Vervolgens hebben we een thematische analyse op de verhalen uitgevoerd om inzicht te krijgen in de betekenis die mensen geven aan kwaliteit van zorg. Verder hebben we vier workshops georganiseerd met artsen, verpleegkundigen en patiëntenverenigingen om erachter te komen hoe zij aankijken tegen de specifieke ervaringen uit het onderzoek en om inzicht te krijgen in de blik van zorgprofessionals op patiëntenervaringen in het algemeen.

Daarnaast zijn tien stakeholders geïnterviewd uit het veld van ziekenhuiszorg om inzicht te krijgen in wat zij doen met patiëntenervaringen en hoe zij aankijken tegen een sterkere rol van patiënten in de zorg. Verder is een inventarisatie gemaakt van de formele en informele manieren waarop patiënten tot juni 2012 inspraak hadden in ziekenhuiszorg en daarnaast hebben we via een analyse van artikelen in drie medische tijdschriften onderzoek gedaan naar visies van artsen op mondigheid en patiëntenparticipatie. Ten slotte zijn de bevindingen van de verschillende onderdelen voorgelegd aan een commissie van ambassadeurs. Deze commissie bestond uit zes mensen met politieke, bestuurlijke en ervaringskennis over zorg in ziekenhuizen.

\subsection{Leeswijzer}

Dit rapport bestaat uit twee delen, een intermezzo en een aantal digitale bijlagen. De digitale bijlagen zijn te vinden op www.rathenau.nl/ patientenwetenbeter

Deel I zet de hoofdlijnen van het onderzoek af tegen de maatschappelijke en politieke ontwikkelingen die leiden tot de huidige discussie over de noodzaak tot versterking van de positie van de patiënt. We bespreken hierin hoe mondigheid wordt opgevat door verschillende actoren, en waarom het nodig is de mondigheid van patiënten in het ziekenhuis te versterken.
Deel II bespreekt in vier thema's uitgebreid de resultaten van de verschillende delen van het onderzoek. We beginnen met een korte introductie van de gebruikte methoden en een uitgebreidere bespreking van de verhalende methode. Dan volgt de kennismaking met de 103 auteurs van de verhalen en de negen verschillende ervaringssituaties die daaruit zijn voortgekomen. Vervolgens geven we een beknopte weergave van de discussies uit de workshops, waarna we de thema's (1) Onzekerheid of angst in een ongewone situatie (2) Moeizame waardering van mondige en actieve patiënten (3) Onmondig in het ziekenhuissysteem, en (4) Onbekende verwachtingen - bij patiënt én zorgverlener, bespreken die uit het gehele onderzoek naar voren zijn gekomen. Deze thema's worden apart besproken en ingeleid door de bijbehorende ervaringsverhalen. Deze ervaringsverhalen representeren steeds een aantal specifieke verhalen van het totale aantal verhalen.

In het intermezzo presenteren we elf projecten die in verschillende ziekenhuizen in Nederland worden uitgevoerd met als doel ervaringen van patiënten een serieuze plek te geven in de zorg, in het bijzonder in het ziekenhuis. In een aantal projecten dienen de ervaringen als concrete basis voor het verbeteren van zorgprocessen. Wij presenteren deze projecten niet als een uitputtende lijst, maar als goede voorbeelden van hoe patiëntenervaringen door ziekenhuizen kunnen worden ingezet voor verbetering van de kwaliteit van de zorg.

De digitale bijlagen I en II bevatten de tabellen van de kwantitatieve analyse en de kenmerken van de schrijvers, en de methodologische verantwoording van de narratieve en thematische analyses, de opzet van de workshops met zorgprofessionals en het verslag van de discoursanalyse. In deze bijlagen kunt $u$ doorklikken naar de uitgebreide analyses en naar de verhalen op de website en waarvoor de auteurs toestemming hebben gegeven voor publicatie. 


\section{Naar een mondige patiënt in de zorg}

Auteurs:

Stans van Egmond en Marjolijn Heerings

2.1 Mondigheid in de spreekkamer: waarover gaat dat eigenlijk? Recent staat de rol van de patiënt in de zorg weer extra in de belangstelling dankzij (politieke) discussies rondom de wetsvoorstellen ter versterking van de positie van patiënten (voorheen Cliëntenrechten Zorg) (zie Kader 3) dat beoogt de positie van de patiënt te versterken. Binnen de Nederlandse zorg was er lange tijd nauwelijks formele ruimte voor het inbrengen van wensen, ervaringen en het perspectief van patiënten. Het was de arts die bepaalde welke zorg een patiënt kreeg. Patiënten hadden geen of zeer weinig invloed op de organisatie van de zorg en op de kwaliteit daarvan. Vanaf de jaren zeventig is daar door verschillende maatschappelijke ontwikkelingen verandering in gekomen. De toename van het opleidingsniveau, een betere verspreiding van kennis en informatie, en de ontzuiling van de samenleving maakten burgers geëmancipeerder, zelfredzamer en mondiger. Dat gold ook voor patiënten. Zij organiseerden zich sinds de jaren zestig al sterker als politieke beweging (Grit et al. 2008). Dat leidde tot de maatschappelijk gedeelde opvatting dat ook patiënten meer autonomie of zelfbeschikking ten aanzien van de eigen ziekte moesten krijgen. Ofwel: mondiger moesten kunnen zijn (Snelders \& Meijman 2009; WRR 2002 Van Beek 1998). Deze mondigheid kreeg allereerst vorm op het niveau van arts-patiëntinteractie: in de spreekkamer.

\section{Informed consent: patiënten informeren en betrekken bij besluitvorming} In 1959 sprak de artsenfederatie KNMG nog over de arts als "een persoon die de volle verantwoordelijkheid voor de belangen van de patiënt, op dit voor hem vaak geheimzinnige terrein, kan overnemen". Dat moest de patiënt in staat stellen "tot een vertrouwensvolle overgave aan de technische bekwaamheid" van de arts (KNMG 1959, p. 19, in: Lelie 1999, p. 61). In 1984 stelde diezelfde KNMG dat voorschriften van een arts "het karakter [dragen] van een medisch advies en laten als zodanig de patiënt het recht hiervan af te wijken" (KNMG 1984, p. 8, in: Lelie 1999, p. 61). De roep om meer autonomie en eigen verantwoordelijkheid voor patiënten heeft, mede dankzij de inbreng van de medische ethiek, vorm gekregen in het begrip informed consent (Struhkamp 2004).

Dat begrip heeft ook geleid tot een meer gelijkwaardige relatie tussen artsen en patiënten. In 1995 is informed consent verankerd in de Wet op de genees- kundige behandelingsovereenkomst (WGBO), en een aantal andere wetten. ${ }^{1}$ Het stelt de patiënt in staat zich te beschermen tegen ongewenste inmenging (Struhkamp 2004). De patiënt heeft het recht duidelijk en volledig geïnformeerd te worden over behandelingen, bijwerkingen en alternatieven, zodat hij of zij gerichte toestemming kan verlenen tot behandeling. Patiënten hebben ook het recht een behandeling te weigeren (behoudens enkele uitzonderingen).

Patiënten hebben daarnaast de plicht artsen informatie te geven over de eigen gezondheid, medicijngebruik en de effecten van de behandeling, én om medewerking te verlenen aan het bevorderen van de eigen gezondheid.

Toch bestaat er in de medische wereld geen overeenstemming over de precieze invulling van informed consent. In de praktijk van de spreekkamer bestaan verschillende invullingen van het begrip. De ene arts geeft bijvoorbeeld meer informatie of betrekt patiënten meer bij de besluitvorming dan de ander (Verberne 2013; KNMG 2001). Bovendien is de interpretatie van het begrip 'zelfbeschik king' (autonomie) in de loop der jaren veranderd, zo blijkt uit een recente wetsevaluatie van ZonMw. Waar voorheen informed consent vooral werd gezien als informeren, instemmen en het recht om nee te zeggen, is er de laatste jaren een ontwikkeling gaande in de richting van 'meer aandacht voor het stimuleren en ondersteunen van patiënten bij het maken van een keuze voor een behandeling en de invulling van hun eigen leven' (Hendriks et al. 2013). Dat kan zich ook uitstrekken tot bijvoorbeeld de effectiviteit van een behandeling. Immers, de patiënt is degene die moet leven met de consequenties van (de keuze voor) een bepaalde behandeling. Dat wat effectief is wordt daarom mede bepaald door het effect op de kwaliteit van leven van de patiënt.

\section{Meer mondigheid en verantwoordelijkheid voor de patiënt voor kwaliteit} van leven en zorg

Het zijn vooral de patiënten-, gehandicapten- en ouderen- (PGO-)organisaties die sinds enige tijd inzetten op een veel radicalere invulling van het begrip autonomie. Zij zetten in op vergroting van mondigheid en meer eigen verantwoordelijkheid van patiënten op basis van de wensen en uitgangspunten van de patiënt zelf. Via programma's voor vraaggestuurde zorg - bekend onder noemers als 'patiëntcentrale zorg', 'zorg 2.0' of 'shared decision making' - wordt ingezet op het vergroten van zelfmanagement en vraaggestuurde zorg bij (vooral) chronische ziekten (Zichtbare Zorg, 2013). De kwaliteit van het leven van mensen met een (chronische) ziekte en de zorg die zij nodig hebben kan sterk verbeteren, wanneer patiënten meer regie hebben over hun behandeling en

1 In dezelfde periode is het klacht-en medezeggenschapsrecht geregeld, via de Kwaliteitswet zorginstellingen (WKZ) in 1993, de Wet klachtrecht cliënten zorgsector (WKCZ) in 1995 en de Wet medezeggenschap clienten zorginstellingen (WMCZ) in 1996. Deze vier wetten vormen het formele raanwwerk voor de positie van de patient in de zorg, vanuit het idee van informed consent. De verschillende onderdelen van het wetsvoorstel Wetsvoorstel Kwaliteit, Klachten en Geschillen in de Zorg (voorheen Cliëntenrechten Zorg) brengen verandering in deze wetten. Nog onduidelijk is op welke wijze dit zal 
wanneer de keuzes in de behandeling meer in overleg tussen arts en patiënt plaatsvinden. Een dergelijke mondigheid gaat een stap verder dan informed consent, omdat de basis van dergelijke zorg al uitgaat van de wensen en vragen van patiënten.

Medische disciplines onderkennen het belang van luisteren naar de wensen van patiënten pas recent en nog mondjesmaat. Zo stelt chirurg Carina Hilders, stafvoorzitter bij de Reinier de Graaf Groep en projectleider 'Medisch Specialist 2015': "Zorg wordt beter als de specialist en de patiënt beiden verantwoordelijk zijn voor het behandelproces, de kwaliteit van leven van de patiënt neemt toe en de therapietrouw is groter" (Zorgvisie, augustus 2013). Conclusies uit onderzoek van Bensing e.a. (2006), zoals dat beter naar patiënten luisteren de kwaliteit van zorg en de autonomie van patiënten ten goede komt en kan zorgen voor optimalisering van de zorg aan individuele patiënten, worden inmiddels wel gehoord. De analyse van medische vakbladen (zie Kader 2) laat zien dat versterking van de rol van patiënten een belangrijk onderwerp gevonden wordt. Toch blijken het voorlopig vooral de voorlopers te zijn die de discussie voeren over vragen als hoe, wanneer en over welke aspecten van zorg de stem van de patiënt gehoord moet worden.

\section{Kader 1: Actief patiëntschap in de ziekenhuiszorg}

Het Rathenau Instituut heeft in 2012 een inventarisatie gemaakt van de mogelijkheden tot inspraak voor patiënten in ziekenhuiszorg.

\section{Formele en informele inspraak}

Formele, maar indirecte, inspraak is geregeld via cliëntenraden (die een of twee keer per jaar overleggen met ziekenhuisbesturen), via enquêtes die de patiënttevredenheid meten en via klachtenprocedures. Informele manieren zijn: lid worden van een patiëntenorganisatie, praten met specialisten en deelnemen aan projecten zoals beschreven in het intermezzo. Met name de laatste twee opties zijn redelijk directe manieren om inspraak te hebben in ziekenhuiszorg. Daarnaast is er medezeggenschap in ziekenhuizen. Maar dit functioneert niet altijd effectief, blijkt uit evaluaties van onder meer ZonMw, het CBO en de OMS. Geschikte patiënten zijn moeilijk te vinden en er bestaat onbegrip bij Raden van Bestuur over het nut en de rol van cliëntenraden (LSR et al. 2006; Voet 2005; ZonMw 2000). Ook onderzoeken van de RVZ uit 2010 en de Inspectie voor de Gezondheidszorg (IGZ) uit 2009 wijzen erop dat patiënten hun rechten nog onvoldoende kunnen uitoefenen vanwege lacunes in het klachtrecht en de WGBO.

\section{Inspraak bij richtlijnontwikkeling en de proms en $\mathrm{CQ}$ indexen}

Een kleine georganiseerde groep patiënten praat op dit moment mee over de vormgeving van de zorg, onder andere via patiëntenorganisaties, in cliëntenadviesraden, in de raden binnen de farmaceutische industrie en bij de ontwikkeling van medische richtlijnen. De grote groep van ongeorganiseerde patiënten wordt daarentegen veel minder vertegenwoordigd. De mening van deze groep patiënten wordt vooral, vaak min of meer toevallig, meegenomen in een steekproefmeting voor bijvoorbeeld een Consumer Quality Index (CO-index, die door het Kwaliteitsinstituut worden gecoördineerd), en de Patient Reported Outcome Measures (PROMS-enquêtes, die door de medische beroepsgroepen worden uitgezet), of wanneer ze een klacht indienen.

Ongeorganiseerde patiënten kunnen hun perspectief op een sterk gestructureerde wijze geven (via een klacht of een meerkeuzeantwoord in een CQ-index) en veelal (m.u.v. een klacht) gericht op het kwantificeerbaar maken van dit perspectief. Er zijn weinig mogelijkheden verhalende ervaringen te plaatsen. De ervaring staat niet centraal en positieve verhalen krijgen nauwelijks ruimte. De patiënt kan bovendien niet zelf het onderwerp bepalen. Mensen die een ziekenhuis bezoeken maar zelf niet ziek zijn, kunnen hun ervaringen helemaal niet kwijt.

\section{Beperkte invloed patiënten}

In de praktijk is de invloed van patiënten vrij beperkt: ze worden laat betrokken bij richtlijnontwikkeling, hebben te maken met moeilijke documentatie, voelen zich onzeker en krijgen weinig houvast op wat voor hen belangrijke onderwerpen zijn. Hierin kunnen de Patiënten en Gehandicapten Organisaties (PGO) nog veel bereiken, want zij kunnen als beste de patiënt empoweren (Smit 2012; Werkgroep wenkend perspectief, 2009). Een nadeel is dat de PGO-beweging de laatste jaren 40 procent van het budget is kwijtgeraakt. Het wetsvoorstel Kwaliteit, Klachten en Geschillen in de Zorg (voorheen wetsvoorstel Cliëntenrechten Zorg) en de formele instelling van het Kwaliteitsinstituut moeten verandering brengen in de manieren waarop patiënten hun mening kunnen uiten over de zorg (VWS, 2011).

(Onderzoek in het kader van een stageopdracht, uitgevoerd door Marthe Stevens, 2012) 
2.2 Marktwerking en de rol van de mondige patiënt

Het thema autonomie is, onder de noemer mondigheid, de laatste jaren sterk verweven geraakt met discussies over marktwerking. Met de invoering van marktwerking in 2006 heeft de overheid ingezet op nieuwe verhoudingen tussen zorgverzekeraars, zorgaanbieders en patiënten. Patiënten vormen het schakelpunt in dit stelsel; de politieke verwachting is dat zij door (deels) vrije keuze voor verzekeraars en zorgaanbieders invloed uitoefenen op de kosten en kwaliteit van de zorg. Het versterken van de positie van de patiënt kan zorgaanbieders prikkelen om hun aanbod meer vanuit de vraag van patiënten te organiseren. In die zin is marktwerking op te vatten als een antwoord op de kritieken op het oude stelsel van aanbodsturing, dat niet goed aansloot bij behoeften van patiënten (Van Egmond 2010). Effectieve marktwerking staat of valt met mondige, actieve patiënten. Immers, patiënten die niet in staat zijn te kiezen of hun mening te laten horen, oefenen geen invloed uit op kwaliteit en kosten van zorg. Dan schiet het middel het doel voorbij.

\section{Weinig invloed voor patiënten op de zorg}

Kritische partijen in het zorgveld voeren de discussie over de noodzaak tot mondiger patiënten op dit moment dan ook vooral in termen van marktwerking. Verschillende PGO-organisaties signaleren dat marktwerking vooralsnog niet heeft bijgedragen aan de versterking van de positie van de patiënt (CBO et al. 2010). De Nederlandse Patiënten en Consumenten Federatie (NPCF) stelt dat "patiënten en patiëntenorganisaties nog te weinig invloed [hebben] op de criteria waarmee de kwaliteit van zorg wordt vastgesteld en waarmee zorgverzekeraars zorg inkopen" (NPCF 2013). Het Centraal BegeleidingsOrgaan (CBO; adviesorgaan voor de gezondheidszorg, een onderdeel van TNO) en de Chronisch Zieken en Gehandicapten Raad (CG-Raad) delen deze kritiek (CG-Raad 2013; CBO 2013). Breed gedragen is de kritiek dat het de patiënt ontbreekt aan goede instrumenten om mondig te zijn.

Marktwerking beperkt op deze manier de (politieke) discussies over versterking van de positie van de patiënt tot discussies over kostenbesparingen en efficiëntie op macroniveau. Daarmee lijken andere legitieme redenen om de rol en autonomie van de patiënt in de zorg te versterken - zoals betere kwaliteit van zorg voor patiënten, betere kwaliteit van leven van patiënten, effectievere artspatiëntcommunicatie -, naar de achtergrond te verdwijnen. Het bemoeilijkt ook een zinvolle discussie over welke aspecten patiënten kunnen en moeten meepraten. Dat zal een reden zijn dat het Wetsvoorstel cliëntenrechten zorg (nu wetsvoorstel Kwaliteit, Klachten en Geschillen zorg) al sinds het eerste wetsvoorstel in 2008 aanleiding geeft tot veel discussies in de Tweede Kamer en ten tijde van het schrijven van dit rapport bij de Eerste Kamer ligt, in afwachting van goedkeuring (zie Kader 3)
2.3 Meer zeggenschap en inspraak voor patiënten, maar waarover eigenlijk?

In de medische wereld is pas recent meer aandacht gekomen voor de rol die de patiënt kan spelen bij het verbeteren van de kwaliteit van zorg. In een aantal baanbrekende rapporten, zoals To Err is Human uit 2000 van het US Institute of Medicine en A Promise to Learn uit 2013 van Don Berwick in opdracht van de Britse National Health Services (NHS) wordt een pleidooi gehouden voor een cultuur van openheid en leren te creëren in plaats van een cultuur van schuld en juridisering in stand te houden. Dit pleidooi om zo meer veiligheidswinst te behalen onderschrijft ook de Onderzoeksraad voor Veiligheid (2013). Het Berwick-rapport gaat daarnaast nog een stap verder. Het beveelt aan om de stem van de patiënt te allen tijde en in elke laag van de organisatie mee te nemen. Deze boodschappen, die ook zijn gericht aan Nederlandse zieken-

huizen, vergen volgens Berwick een omslag in het denken over goede medische zorg, waarbij het gaat om vragen als: waaruit bestaat goede zorg en wie mag daarover meepraten.

\section{Goede zorg: de uitkomst van professionele, organisatorische en}

\section{relationele dimensies}

Goede zorg is door de IGZ gedefinieerd als de uitkomst van zes elementen: veiligheid, effectiviteit, tijdigheid, doelmatigheid, patiëntgerichtheid en gelijke verdeling naar behoefte (IGZ, 2009). Deze zes elementen hebben betrekking op drie dimensies: de professionele, organisatorische en relationele dimensie van zorg (IGZ 2009), die in 2001 zijn geformuleerd door het Amerikaanse Institute of Medicine in het rapport Crossing the Quality Chasm. Van goede zorg op deze niveaus is sprake als de zorg veilig, effectief en doelmatig is, tijdig wordt geleverd, gericht is op de patiënt, en naar behoefte gelijkelijk wordt verdeeld. Deze dimensies komen terug in de WBGO en de Kwaliteitswet zorginstellingen, en vormen de basis voor de 'Gedragsregels voor artsen' van de KNMG en de Orde van Medisch Specialisten. Het wetsvoorstel Kwaliteit, Klachten en Geschillen zorg beoogt de definitie van goede zorg uit te breiden met het patiënten perspectief. In het voorstel is de eis opgenomen tot goede afstemming van zorg tussen de verschillende zorgverleners waarmee een cliënt te maken heeft. Wat dat in de praktijk kan betekenen voor de inspraak patiënten in de zorg is nog onduidelijk en behoeft nadere invulling.

\section{Zeggenschap over en inspraak in goede kwaliteit van zorg}

In de Nederlandse ziekenhuispraktijk is de laatste jaren veel aandacht uitgegaan naar het verhogen van de professionele kwaliteit van zorgverleners via nascholing richtlijnontwikkeling, visitaties, complicatieregistraties en de ontwikkeling van prestatie-indicatoren. Op dit niveau is slechts een kleine plaats ingeruimd voor de stem van de patiënt, bijvoorbeeld bij richtlijnontwikkeling. Het wetsvoorstel KKGz brengt daar nauwelijks verandering in. Het belang van een goede organisatie van zorg wordt inmiddels erkend. Voor een deel overlapt de organisatorische dimensie met de relationele kwaliteit. Deze laatste heeft betrekking 
op patiëntgerichtheid, en gaat over onder meer bejegening, informeren en communiceren met de patiënt, medebeslissingsrecht voor patiënten en het inrichten van zorg volgens de wensen en uitgangspunten van patiënten. Huidige kwaliteitsmetingen van de organisationele en relationele kwaliteit worden gecoördineerd door het Kwaliteitsinstituut Zorg. Deze metingen nemen vooralsnog een kleine plek in, afgezet tegen de hoeveelheid aan meetinstrumenten voor professionele kwaliteit en veiligheid van zorg (IGZ / Bont et al. 2009). Zowel de meetmethoden als manieren om de uitkomsten om te zetten in organisatorische en relationele verbeteringen zijn nog volop in ontwikkeling. Dat wordt ook erkend, in de interviews, door de verschillende beroepsgroepen en de brancheorganisatie voor ziekenhuizen (NVZ, 22-04-2013; V\&VN, 21-05-2013; CBO, 28-05-2013).

Op dit moment is de meest gebruikte manier om de mening van de patiënt over de kwaliteit van ziekenhuiszorg te kennen via patiënten enquêtes. Hoewel de enquêtes externe verantwoording bieden, leveren ze vooralsnog te weinig inzichten op om zorg beter te organiseren rondom de wensen en uitgangspunten van de patiënt. Bovendien zijn er hoge kosten mee gemoeid, en is de informatie die het oplevert vrij algemeen: "Je kunt wel de grootste bottlenecks eruit filteren, maar het blijft oppervlakkige informatie, uiteindelijk" (interview NVZ, 22-04-2013). Een reden daarvoor is dat kwaliteit en veiligheid in ziekenhuizen een complexe samenstelling is van professionele, organisatorische en relationele eisen die niet altijd los van elkaar gezien kunnen worden (Buikema 2011; Klein 2010).

\section{Kader 2: Sterkere positie voor patiënten:} artsen tussen hoop en huiver

Hoe kijken artsen aan tegen de veranderende positie van de patiënt? Een discoursanalyse van 51 artikelen, geschreven door artsen in medische vakbladen, laat zien dat de publicerende artsen voorstander zijn van het versterken van de positie van de patiënt.

Om die positie te versterken is een betere omgang door artsen met patiënten nodig, vooral op het gebied van communicatie, aldus de publicerende artsen. Meer uitleg, beter luisteren naar wensen en opvattingen van de patiënt en deze meer respecteren zijn onderdelen van betere communicatie. Voorwaarden hiervoor zijn voldoende tijd voor een consult, vaardigheden bij de arts als inlevingsvermogen en kunnen reflecteren op het eigen handelen. Ook gezamenlijke besluitvorming vormt een onderdeel van een betere relatie tussen arts en patiënt. Andere manieren om de positie van de patiënt te versterken, zijn onder meer: organisatie van zorg vanuit de vraag van de patient en niet vanuit het aanbod, transparantie over kwaliteit van zorg voor de patiënt, en meer gebruik van ICT-toepassingen in de zorg.

De artikelen verschenen in de periode 2005 tot 2007 en 2012 en 2013 in de medische vakbladen Medisch Contact, het Nederlands Tijdschrift voor Geneeskunde en op Artsennet.nl. Deze werden doorzocht op de zoektermen autonomie, patiënt centraal, patiëntenparticipatie, zorgconsument, zorgregie en zorg 2.0. Alle artikelen waarvan de schrijver een arts was en waarvan het onderwerp betrekking had op de positie van de patiënt in ziekenhuiszorg of in het zorgstelsel in het algemeen zijn geanalyseerd.

De toon van de meeste artikelen was positief en vaak zelfs enthousiast en overtuigend. De schrijvende artsen zien de noodzaak tot het versterken van de positie van de patiënt. Daarbij zetten schrijvende artsen zich in hun artikel veelal af tegen de heersende opvatting dat het versterken van de positie van de patiënt ongewenst is. Illustratief hiervoor is een citaat van Ben Crul, huisarts en hoofdredacteur van Medisch Contact:

"Laten we de patiënt en zijn mening waarachtig toe in onze beroepsuitoefening of wordt zijn inbreng vooral gedoogd? Wordt hij alleen maar gepamperd als een lijdend voorwerp waarmee we onze boterham verdienen? Pro forma wordt zijn mening gevraagd omdat dat nu eenmaal moet, maar doet $u$ het van harte? Velen van u bestempelen de kritische zorgconsument toch eerder als lastig dan als een aanwinst" (Crul, 2007).

Publicerende artsen zijn dus overwegend voorstander van het versterken van de positie van de patiënt door gedeelde besluitvorming, vraaggerichte organisatie van zorg, transparantie over kwaliteit van zorg en het gebruik van ICT-toepassingen. Of dit ook de heersende opvattingen zijn op de werkvloer van het ziekenhuis komen we uit de artikelen niet te weten. Maar een portie enthousiasme en overredingskracht lijken wel nodig om de werkvloer mee te krijgen.

Onderzoek in het kader van een stageopdracht, uitgevoerd door Wouter Verberne, 2013) 
2.4 Het perspectief van de patiënt draagt bij aan goede kwaliteit van zorg

De stem van de patiënt laat zich nog moeizaam horen in het ziekenhuis, blijkt uit het voorgaande, of dat nu gaat over eigen verantwoordelijkheid en regie voo patiënten over de behandeling of over het kennen van het functioneren van ziekenhuizen door middel van het perspectief van de patiënt.

Ons onderzoek naar ervaringen van patiënten met ziekenhuiszorg laat zien dat het perspectief van patiënten erg waardevol is voor het verkrijgen van inzicht over kwaliteit van ziekenhuiszorg. Patiënten zijn degenen die het hele proces ervaren, van binnenkomst tot vertrek uit het ziekenhuis. Uiteraard beperkt de ervaring van de patiënten zich tot dat deel dat de patiënt kan zien of ervaren. Dat wat in de operatiekamer gebeurt terwijl de patiënt onder narcose is, kan een patiënt niet beoordelen. Maar een in de operatiekamer opgelopen wondinfectie merkt een patiënt wel op, evenals de manier waarop zorgverleners omgaan met een dergelijk incident. Patiënten kunnen ook opmerken of een foutief medicijn toegediend wordt of dat hij of zij te weinig geïnformeerd wordt naar zijn zin. Patiënten zien misschien maar een klein deel, maar ze zien dingen die anderen niet opmerkingen en ze zien het hele zorgproces (vanuit het bed). Dat wat ze zien is waardevol genoeg om serieus te nemen. Dat maakt patiënten bij uitstek geschikt als bron van kennis over het functioneren van ziekenhuizen.

\section{Goed geïnformeerd worden en een efficiënte organisatie van zorg}

Patiënten hebben, zo blijkt uit de analyses van de verhalen, duidelijke ideeën over wat kwaliteit van zorg en patiëntgerichte zorg is. Deze ideeën komen voor een groot deel overeen met de bovengenoemde drie dimensies van goede zorg. De patiënten die in dit onderzoek aan het woord komen merken op dat het belangrijk is voor goede zorg dat: zorg tijdig is, doelmatig, patiëntgericht, veilig en professioneel. En dat patiënten goed geïnformeerd worden. Daarnaas wordt een goede en efficiënte organisatie van zorgprocessen genoemd als een belangrijk onderdeel van goede en veilige zorg. Patiënten noemen zaken als het op orde hebben van dossiers, een goede toediening van medicijnen, het op de juiste wijze ontslaan van patiënten uit het ziekenhuis, en vele andere zaken.

De ervaringsverhalen geven veel inzicht in de relationele aspecten van zorg. Uit de verhalen komt naar voren dat goede zorg betekent dat de zorgprofessional aandacht en inlevingsvermogen heeft en de patiënt op de juiste manier bejegent. En bejegening gaat voor veel patiënten verder dan aardig aangesproken worden. Hoewel goede omgangsvormen ertoe doen, beschrijven patiënten bejegening als aandacht voor de wanhoop en angst die patiënten kunnen voelen wanneer zij worden geconfronteerd met een plotselinge aandoening, een ongeluk of een andere aanleiding waarvoor een ziekenhuisopname nodig is. Goede zorg betekent voor veel patiënten dat zorgprofessionals goed luisteren naar wat patiënten te zeggen hebben over hun fysieke toestand en hun suggesties over de diagnose en behandeling serieus overwegen.
Goede zorg betekent ook dat zorgprofessionals patiënten goed informeren over wat er gaande is en wat er verwacht kan worden tijdens een bezoek aan ziekenhuis of polikliniek; van goede informatie over de diagnose tot de eventuele testen die gedaan moeten worden om tot een diagnose te komen, tot de eventuele behandeling en het verblijf in het ziekenhuis. Ook willen mensen het graag horen als er (nog) niet veel over te zeggen valt. Eén van de allerbelangrijkste onderdelen van goede zorg voor veel patiënten is dat de zorginstelling of individuele zorgverlener ook de partner of vertegenwoordiger van de patiënt serieus neemt als gesprekspartner.

Patiënten kunnen dus veel inzicht geven in de relationele aspecten van zorg. Zij zijn een goede ingang in de black box die een ziekenhuis vaak is. Ziekenhuizen kunnen deze inzichten gebruiken om deze aspecten van zorg te verbeteren.

Maar een voorwaarde is wel dat patiënten gehoord worden.

\subsection{Hoe kan de patiënt het uitgangspunt worden voor} ziekenhuiszorg?

Uit ons onderzoek blijkt dat patiëntenervaringen goede inzichten kunnen opleveren over de rol van patiënten in de zorg en over de kwaliteit van ziekenhuiszorg. In de praktijk laat de stem van de patiënt zich nog moeizaam horen in het ziekenhuis. Bovendien kent de patiënt nog steeds weinig wettelijke middelen om werkelijk vorm te geven aan het actief meedenken. Ziekenhuisdirecties en de overheid kunnen deze kanteling naar het vergroten van de stem en positie van de patiënt in het ziekenhuis ondersteunen.

\section{Draagvlak voor patiëntenervaringen}

Zoals gezegd wordt vanuit verschillende hoeken aangedrongen op een kanteling in het denken van zorgprofessionals en besturen van ziekenhuizen naar het beter inzetten van de patiënt zelf bij het zorgproces. Ook de Minister van Volksgezondheid benadrukt in haar beleid voor de langdurige zorg de grote rol voor patiëntenervaringen in het creëren van meer transparantie over het functioneren van ziekenhuizen, (Kamerstukken I, 2013). Langzaam lijkt tot ook ziekenhuizen het belang van het patiënten perspectief door te dringen. Uit de workshops blijkt dat individuele artsen en verpleegkundigen doordrongen zijn van het nut van patiëntenervaringen. Er worden ook beperkingen gezien. Mevr. M. Bennema van de Orde van Medisch Specialisten (OMS) merkt in het interview op dat 'medisch specialisten verantwoordelijkheid (willen) nemen voor het meten en duiden van het medisch inhoudelijke deel (..), maar niet voor meting van algemene- en service aspecten' (interview OMS, 20130521). Een reden die daarvoor wordt genoemd, door meerdere organisaties, is dat te veel meten ten koste kan gaan van het draagvlak onder medische professionals om kwaliteit van zorg te meten. 
Ook de beroepsvereniging Vereniging van Verpleegkundigen en Verzorgende Nederland (V\&VN) ziet het nut van ervaringen naast enquêtes, ook gezien de moeizame vertaalslag van uitkomsten van enquêtes naar verbetertrajecten. De V\&VN merkt op dat 'als bijvoorbeeld de bejegening laag scoort op een afdeling je als verpleegkundige moet uitzoeken waarom dat zo is - en dan ga je in gesprek, denk ik' (interview V\&VN, 20130521). ledere afdeling zou dat op eigen wijze moeten doen, maar een gesprek met patiënten zou hierin zinvol kunnen zijn, volgens de beroepsvereniging.

De overheid probeert zorgaanbieders en verzekeraars te bewegen tot het beter inzetten van ervaringsdeskundigheid van patiënten. Het doel van het beter inzetten van ervaringsdeskundigheid is om kwaliteit van zorg te verbeteren en de zorg meer te organiseren rondom de vraag en wensen van patiënten. Nu zijn zorginstellingen nog te veel georganiseerd rond hun aanbod. Het wetsvoorstel KKGz en het instelling van het Kwaliteitsinstituut leggen hiervoor een wettelijke basis. In meerdere toelichtingen op (delen van) deze wet wordt gesproken van een cliëntgerichte werkwijze. Hoe die cliëntgerichte werkwijze eruitziet en hoe die werkwijze in verschillende zorgsettings vorm moet krijgen, is echter niet helder. Het $\mathrm{CBO}$ merkt dat medewerkers in ziekenhuizen zich soms afvragen wat alle moeite om verantwoord en patiëntgericht te werken nu oplevert (interview CBO, 20130528). Het is blijkbaar nog niet vanzelfsprekend dat investeren in patiënten naast kwaliteit ook tijd kan opleveren en dat het de zorg goedkoper maakt. Maar dat kan volgens het CBO alleen als een organisatie tijd stopt in dergelijke projecten.

\section{Expliciete opdracht voor de medische professie en ziekenhuisbesturen}

Het zou voor de medische beroepsgroepen een meer expliciete opdracht kunnen zijn de vraag centraal te zetten hoe patiënten beter betrokken kunnen worden bij het eigen zorgproces. Op dat vlak kan nog veel gefaciliteerd worden. Een eerste stap kan zijn om het de patiënt gewoon te vragen. Het verzamelen en leren van goede voorbeelden van elders zou een tweede goede stap kunnen zijn voor ziekenhuizen. Zij vinden daarin het Zorginstituut en ZonMw als partner. Een aantal initiatieven, waarbij ziekenhuizen de patiënt als uitgangspunt nemen bij verbetering van zorgprocessen, staat in dit boek beschreven. Een volgende stap is om dit tot een blijvend proces te maken waarin luistervermogen ontwikkeld wordt. Dat is nodig om de patiënt een echte stem te geven in de zorg die ertoe bijdraagt dat zorgprocessen ten dienst komen te staan van de patiënt, en niet andersom.

\subsection{Aanbevelingen}

In de ziekenhuiszorg wordt steeds meer uitgegaan van de mondige patiënt die een actieve inbreng in het eigen zorgproces heeft.

Toch kan in ziekenhuizen nog een flinke slag gemaakt worden om deze patiëntgerichtheid te ondersteunen. De zorg wint aanzienlijk aan kwaliteit als binnen het zorgproces meer structurele aandacht uitgaat naar de wensen en behoeften van patiënten. Dat vergt een andere inrichting van het zorgproces, bijvoorbeeld door gebruikt te maken van (positieve en negatieve) verhalende ervaringen van patiënten als vast onderdeel van de kwaliteitszorg van ziekenhuizen. Om patiëntgerichte zorg te versterken doen we de volgende aanbevelingen aan ziekenhuizen en zorgverzekeraars:

- Ziekenhuizen kunnen hun organisatorisch leervermogen vergroten door structureel gebruik te maken van positieve én negatieve verhalende patiëntenervaringen.

- Ziekenhuizen kunnen de luistervaardigheden van zorgverleners in he ziekenhuis verbeteren door het inzetten van instrumenten zoals beschreven in dit onderzoek, bijvoorbeeld de Elst Borst-gesprekken een patiëntluisteraar of een ander instrument.

- Zorgverzekeraars kunnen een rol spelen in het verwezenlijken van beide aanbevelingen door financiering van dergelijke projecten of via contractafspraken met ziekenhuizen.

- Voor het sturen van verwachtingen van patiënten is het van belang dat ziekenhuizen duidelijk maken wat patiënten van het ziekenhuis kunnen verwachten en wat niet, bijvoorbeeld door deze informatie te integreren in bestaande communicatiemiddelen zoals de website, sociale media, folders, het opnamegesprek en het ontslaggesprek.

- Voor het versterken van patiëntgerichte zorg kunnen ziekenhuizen en zorgverzekeraars de volgende instrumenten inzetten:

1. Maak gebruik van verschillende methoden die ingezet kunnen worden voor kwaliteitsverbetering, bijvoorbeeld beschreven in het intermezzo in dit boek, zoals de verhalen van patiëntenervaringen.

2. Zet de klachtenfunctionaris in, zoals omschreven in het wetsvoorste WKKGZ. Deze kan, naast klachten en onvrede, ambivalente en positieve ervaringen opnemen ter verbetering van kwaliteit van zorg

3. Neem het leren van ervaringen op in de criteria voor klachtenprocedures.

4. Stel patiënten actief op de hoogte over de mogelijkheid ervaringen te delen, en stel ze, door middel van bestaande communicatiemiddelen, steeds op de hoogte tot welke verbeteringen in de zorg dit heeft geleid. 
Kader 3: Via het Wetsvoorstel cliëntenrechten zorg (WCZ) en het Wetsvoorstel Kwaliteit, Klachten en Geschillen in de Zorg naar een verdere uitbreiding van patiëntenrechten

Sinds 2006 zijn door diverse Kabinetten, onder druk van partijen uit het veld - zoals de Nederlandse Patiënten Consumenten Federatie (NPCF) aanzetten gedaan om tot een regelgevend kader te komen die de positie van de patiënt moeten versterken. Dat leidde in 2008 tot het wetsvoorstel cliëntenrechten zorg (WCZ). Deze is in juli 2013 in gewijzigde vorm aangenomen door de Tweede Kamer als WKKGZ. De vele discussies zijn hieronder samengevat, voor zover die betrekking hebben op ziekenhuiszorg.

\section{Een nieuwe definitie van goede zorg: het perspectief van de cliënt} wordt belangrijker

In 2009 werd het wetsvoorstel WCZ door de toenmalige Ministerraad goedgekeurd. Het vernieuwende van dit voorstel was de formulering van goede zorg als cliëntcentrale zorg rondom wie de zorgaanbieder de zorg moet organiseren, en goede zorg als recht van de patiënt i.p.v. plicht van de zorgaanbieder (Kamerstukken II 2012). De WCZ moest bovendien vijf wetten vervangen (de Kwaliteitswet zorginstellingen, de Wet klachtrecht cliënten zorgsector, de Wet medezeggenschap cliënten zorginstellingen, de Wet toelating zorginstellingen en de Wet op de geneeskundige behandelingsovereenkomst (WGBO) en zou tevens een wijziging aanbrengen in de Wet op de beroepen in de individuele gezondheids zorg (Wet BIG), en vijf cliëntenrechten regelen: 1) recht op goede zorg: kwaliteit en veiligheid; 2 ) informatie, toestemming, dossiervorming en privacy; 3) keuzeinformatie; 4) een laagdrempelige klachten- en geschillenbehandeling; 5) medezeggenschap. Daarnaast regelde deze wet twee plichten voor zorgaanbieders: 1) de plicht van goed bestuur en toezicht; 2) de plicht van verslaglegging en maatschappelijke verantwoording (NIVEL 2012).

Het voorstel leidde bij verschillende partijen in de Tweede Kamer tot angst dat het vervangen van de WGBO en het regelen van goede zorg als recht van de patiënt en niet als plicht van de zorgaanbieder zou leiden tot een versobering van de rechten van cliënten. Bovendien diende de wet teveel belangen - van patiëntenrechten tot winstuitkering uit zorginstellingen -, en kon men de uitwerking ervan in de praktijk niet goed overzien. Bij het vallen van kabinet-Rutte I in het voorjaar van 2012 werd het voorstel controversieel verklaard. Bovendien besloot de Kamer de WGBO niet te vervangen, maar wel het recht op goede zorg op te nemen als plicht voor de zorgaanbieder.

\section{Wet Kwaliteit, Klachten, en Geschillen in de Zorg: goede zorg een} plicht voor de zorgaanbieder

In februari 2013 kondigde de Minister van Volksgezondheid, Welzijn en Sport aan de WCZ op te knippen in vijf afzonderlijke delen. De onderdelen 1) Klachten en geschillen en 2) Kwaliteit zijn in de Wet kwaliteit, klachten en geschillen in de zorg (WKKGZ) op 4 juli 2013 aangenomen door de Tweede Kamer. Daarmee komen de Kwaliteitswet zorginstellingen en de Wet klachtrecht cliënten zorgsector te vervallen. De delen 3) goed bestuur en medezeggenschap, 4) de aanpassing van de WGBO en 5) aanpassing van de Wet toelating zorginstellingen moeten nog worden voorgelegd aan de Tweede Kamer (VWS 2013).

\section{Laagdrempeliger klachtenprocedures}

De WKKGZ heeft in elk geval geleid tot een bredere definitie van goede zorg dan tot nu toe gehanteerd. Goede zorg houdt straks ook in dat deze meer op de wensen van de cliënt is gericht, via de eis tot goede afstemming van zorg tussen de verschillende zorgverleners waarmee een cliënt te maken heeft. Bovendien maakt de wet de behandeling van klachten laagdrempelig en effectiever. ledere zorginstelling is verplicht een persoon aan te stellen bij wie cliënten terecht kunnen met klachten én onvrede over de zorg, en moet moeite doen de onvrede van de cliënt zo veel mogelijk weg te nemen. De klacht kan als signaal voor kwaliteitsverbetering dienen (Kamerstukken II 2011). Nabestaanden of vertegenwoordigers van overleden cliënten kunnen nu ook een klacht indienen. Daarnaast moeten zorginstellingen zich aan sluiten bij een geschillencommissie, wier uitspraken bij formele klachten bindend zijn. Zij kan ook een schadevergoeding toekennen. De bestaande klachtencommissies zijn niet langer verplicht. In januari 2014 zijn de twee onderdelen van de WKKGz besproken in de Eerste Kamer. De uitkomst daarvan was ten tijde van het afronden van dit rapport nog onbekend.

\section{Instelling van een overkoepelend orgaan voor}

\section{patiëntenervaringen in de zorg}

In december 2013 is de wet aangenomen waarmee het College Zorgverzekeringen omgevormd is tot het Zorginstituut Nederland en is het Kwaliteitsinstituut Zorg (KIZ) hier geïnstalleerd. Het KIZ werkt aan kwaliteitsverbetering in de zorg via patiëntenervaringen. Het stimuleert beroepsgroepen en patiëntvertegenwoordigers in het gezamenlijk ontwikkelen van kwaliteitsstandaarden, en zorgt ervoor dat keuzeinformatie voor cliënten tot stand komt. 


\section{Elf voorbeelden van initiatieven om ervaringen van patiënten bruikbaar te maken voor kwaliteits- verbetering in ziekenhuizen}

\section{Chief Listening Officer}

De Chief Listening Officer brengt de behoeften van patiënten en hun naasten rond (ziekenhuis)zorg in kaart. De inzet van de Chief Listening Officer biedt inzicht in de behoeften van patiënten en analyseert met welke aanpassingen de zorg beter kan aansluiten bij die behoeften. Op dit moment is in Nederland één Chief Listening Officer werkzaam. De Chief Listening Officer wordt betaald door de zorginstelling.

Corine Jansen is Chief Listening Officer voor onder andere het REshape \& Innovation Center van het Radboudumc in Nijmegen.

\section{Luisteren}

"Door goed te luisteren geef ik de patiënt en zijn naasten het gevoel dat ze gehoord worden, dat ze ertoe doen. Op basis van wat ik hoor, maak ik een analyse van wat er is gebeurd en hoe het beter kan."

"Ik ga luisteren vanuit een specifieke vraag van een medische afdeling. Eerst selecteer ik, samen met de afdeling, een dwarsdoorsnede uit de patiëntenpopulatie. Met deze geselecteerde patiënten voer ik een goed gesprek over hun ervaringen en wat het ziekenhuis daarvan kan leren. Daarbij is het een voordeel dat ik niet bij het behandelteam hoor. De patiënten zijn niet van mij afhankelijk en kunnen dus vrijuit praten. Uit die gesprekken haal ik een aantal grote lijnen. Die geef ik, ondersteund met quotes, door aan de afdeling. Samen kunnen we dan bekijken wat er beter kan."

\section{Informatievoorziening}

"Een mooi voorbeeld is een afdeling voor vrouwen met kanker die wilde weten hoe patiënten de zorg en de communicatie daaromheen ervaren en hoe zij de kwaliteit van zorg konden verbeteren. Uit de gesprekken met de vrouwen kwam onder meer naar voren dat veel vrouwen eigenlijk niet goed weten hoe hun lichaam in elkaar zit. Ze weten bijvoorbeeld niet precies waar hun baarmoeder of eierstokken zitten. Ook bleek dat zorgprofessionals praten over kanker en chemotherapie alsof dat heel gewoon is, maar dat de vrouwen om wie het gaat eigenlijk niet goed wisten wat het was."

"Daarom hebben we de informatievoorziening verbeterd. De patiënten krijgen nu een informatiemap met daarin onder meer een gedetailleerde tekening: dit is úw onderlichaam en híer heeft u kanker. De map bevat ook een algemene informatiefolder over kanker en chemotherapie en een agenda met het vervolg traject. Ook krijgt elke nieuwe patiënt nu eerst een gesprek met een arts en vervolgens met een verpleegkundige. De arts en de verpleegkundige maken op basis van dat gesprek een inschatting over wat de patiënt qua informatie kan verwerken en passen de map daarop aan."

\section{Nodig}

"De functie van Chief Listening Officer is niet ontstaan omdat zorgprofessionals zelf niet zouden luisteren. Dat doen ze namelijk wel. Ik ben er om zonder horloge, in een rustige omgeving en zonder afhankelijkheidspositie het dieperliggende verhaal te horen. Waardoor we als zorginstelling efficiënter en kwalitatief nog betere zorg verlenen, omdat we véél beter weten wat mensen werkelijk nodig hebben."

\section{Focusgroepen}

Focusgroepen zijn open gesprekken tussen acht tot twaalf patiënten. Die praten met elkaar onder leiding van een gespreksleider over onderwerpen die deels vooraf zijn vastgesteld. De gesprekken leveren inzicht op in zaken die patiënten belangrijk vinden en waar het ziekenhuis de kwaliteit en de service kan verbeteren.

Ad Koster is specialist op de afdeling oncologie en hematologie van het VieCuri Medisch Centrum. In het kader van een project van het $C B O$ organiseerde hij focusgroepen op zijn afdeling. Kapstok daarvoor waren onderwerpen uit klanttevredenheidsonderzoeken, aangevuld met de resultaten van een QuickScan waarin patiënten en zorgverleners verbeterpunten benoemden.

\section{Vragen}

"Als je echt wilt weten wat mensen willen, moet je ze dat vragen. Dat is wat in zo'n focusgroep gebeurt. Wij doen wel al klanttevredenheidsonderzoek via schriftelijke enquêtes, maar hadden regelmatig het idee dat we daarmee niet de vinger konden leggen op wat bij patiënten werkelijk speelt. We werken ook met een klantenwenskaart. Daarop schrijven mensen drie punten die ze goed vinden en drie die voor verbetering vatbaar zijn. Ik heb inmiddels tientallen klanten- 
wenskaarten terug. Maar de opbrengst is heel beperkt. Patiënten geven vrijwel zonder uitzondering aan heel tevreden te zijn. Dat is fijn om te horen, maar contrasteert met de uitkomsten van de focusgroepgesprekken."

"Neem de informatievoorziening. Van de patiënten hoorden we dat zowel de mondelinge als de schriftelijke informatie over de ziekte en behandeling beter kon. Terwijl wij als verpleegkundigen en medische staf altijd het idee hadden dat we dat goed doen. Ook de uitkomst van klanttevredenheidsonderzoeken was steeds positief. Op basis van de gesprekken in de focusgroepen hebben we de informatievoorziening nu verbeterd."

\section{Medisch psycholoog}

"Uit de focusgroepen kwamen ook punten naar voren die niet in het klanttevredenheidsonderzoek aan de orde komen. Zo bleken patiënten behoefte te hebben aan een meer laagdrempelige doorverwijzing naar een medisch psycholoog voor begeleiding. Zoiets is natuurlijk relatief eenvoudig te realiseren."

\section{Eenheid}

"Een groter punt was dat onze patiënten weinig eenheid ervoeren tussen de drie afdelingen waarmee ze te maken krijgen. Patiënten komen naar het spreekuur in de polikliniek, worden opgenomen op de klinische afdeling en krijgen chemotherapie op de dagbehandeling. We hoorden dat de ene afdeling niet goed op de hoogte was hoe het er op de andere aan toe ging. Dat is iets wat wij als staf wel herkennen, maar wat uit die klanttevredenheidsonderzoeken eigenlijk nooit naar voren kwam. Voor ons reden om actie te ondernemen."

"Een aantal grote reorganisaties, zoals de verplaatsing van de dagbehandeling naar een locatie naast de klinische afdeling, stond voor de focusgroepen al op stapel. Op korte termijn gaan we verpleegkundigen van de dagbehandeling uitwisselen met verpleegkundigen van de klinische afdeling, zodat die weten wat er op de andere afdeling gebeurt. Voor nascholing nodigen we nu ook de verpleegkundigen van de andere afdelingen uit."

\section{Implementatie}

"Het is belangrijk dat de professionals die de focusgroepen organiseren en nadenken over de implementatie van de verbeterpunten uit verschillende geledingen van het ziekenhuis komen. lemand vanuit het management, een oncologieverpleegkundige, iemand uit de cliëntenraad, ikzelf als medisch specialist en een consultant. Die laatste geeft organisatorische en administratieve ondersteuning en houdt ons ook steeds weer bij de les. Heel plezierig, want als je zelf steeds die kar moet trekken, weet je vaak al dat het gaat verwateren omdat je het gewoon te druk hebt met andere dingen." "ledereen doet het bij ons naast zijn gewone werk, deels binnen en deels buiten werktijd. Als vrijgevestigd specialist moet je ook bereid zijn om inspanningen te leveren om je eigen winkel te verbeteren. Wil je het echt structureel aanpakken, dan moet je er als organisatie tijd voor vrijmaken. En tijd is: geld. Belangrijk is ook dat je het simpel houdt. Maakt het niet te omvangrijk, want dat is tijdrovend en dus moeilijk om te continueren. Focusgroepen zijn relatief eenvoudig te organiseren."

\section{Patiëntenervaringen in boekvorm}

Stichting CCC (Coleta's Chronische Circus) verzamelt de verhalen van patiënten in boekvorm. De collectie bestaat inmiddels uit 2.700 boeken en talloze links naar blogs, egodocumenten en initiatieven op de website patiëntervaringsverhalen.nl. CCC draait op ongeveer dertig vrijwilligers en ontving eenmalige subsidies van ZonMw en VSB fonds. Overige inkomsten haalt de stichting uit donaties en werkzaamheden voor onderzoekers, zorgverleners en opleidingen. De initiatiefneemster van de stichting vult het budget aan uit privégelden.

Initiatiefneemster Coleta Platenkamp van CCC is medisch socioloog, werkte in de hulpverlening en was betrokken bij het opleiden van verpleegkundigen.

Toen zijzelf chronisch ziek werd, had ze veel steun aan het lezen van ervaringsverhalen. Zij besloot deze verhalen te verzamelen en voor anderen beschikbaar te stellen. Als gids ondersteunt zij onderzoekers, studenten en andere geïnteresseerden bij het zoeken naar informatie uit de collectie.

Gids

"Wij willen met de stichting een gids zijn voor patiëntenervaringsverhalen. Want er kan nog veel geleerd worden van de ervaringen van patiënten, dat heeft een extra meerwaarde. We willen een dialoog op gang brengen waarin de stem van de patiënt wordt gehoord en meetelt."

"De verhalen uit de collectie dragen bij aan de zoektocht naar goede zorg. Ze worden op steeds meer onderwijsplekken gebruikt in opleidingen geneeskunde of HBO-Verpleegkunde. Opleidingen voor ervaringsdeskundigen geven wij tips voor boeken. Ook onderzoekers weten ons te vinden."

"Als ervaringsdeskundige combineer je de kennis van je ziekte met je eigen ervaringen als patiënt. Maar hoe weet je dat andere patiënten diezelfde ervaringen hebben? Daarin kunnen de patiëntenboeken veel betekenen Die boeken vertellen vaak het hele verhaal en dat levert verrassende inzichten 
op. In verhalen van patiënten over Spoedeisende Hulp zie je bijvoorbeeld dat er al veel misgaat in het voortraject. Dat was een eyeopener voor een onderzoekster naar kwaliteitsverbetering op de Spoedeisende Hulp en een aanvulling op haar eigen observaties ter plaatse."

\section{Context}

"Een van de problemen die we tegenkomen bij het gebruik van de patiëntenverhalen is dat mensen in betaalde banen de patiënten gaan vertegenwoordigen. Dan is niet de patiënt zelf aan het woord, maar een vertegenwoordiger die ook andere belangen heeft. Het gevaar is dan dat het verhaal uit de context wordt gehaald. Vanuit de beste bedoelingen wordt gedacht: dit is wat de patient wil. Maar de patiënt zelf herkent zich niet meer in het verhaal. Daarom is het belangrijk steeds terug te gaan naar de bron van de patiëntenervaring. Door bijvoorbeeld aan schrijvers zelf te vragen wat de belangrijke thema's of citaten in het verhaal zijn. Of door de conclusies aan de schrijvers voor te leggen. Dan blijf je bij het verhaal van de patiënt en blijft zijn verhaal heel."

\section{Kennisbron}

"Er zijn zoveel ervaringsverhalen in boekvorm gepubliceerd! Rijke verhalen waarin patiënten vertellen over hun leven, over hoe ze met de ziekte omgaan, over hun weg door het ziekenhuis en het zorgcircuit. Die verhalen vormen een enorm rijke kennisbron! Hulpverleners, patiëntenvertegenwoordigers, onderzoekers, opleidingen en beleidsmakers kunnen daar veel meer mee doen."

\section{Spiegelbijeenkomsten}

Spiegelbijeenkomsten zijn kringgesprekken waarin een groep patiënten feedback geeft over hun ervaringen aan zorgverleners. Het ziekenhuis bekostigt deze bijeenkomsten. De spiegelbijeenkomsten leveren verbeterpunten op voor de organisatie en voor individuele hulpverleners op het gebied van bejegening en self efficiency.

De eerste spiegelbijeenkomsten werden in 1999 gehouden op de afdeling neonatologie van het Amsterdam Medisch Centrum (AMC). Daarna werden ze in de hele AMC-organisatie ingevoerd. Huisarts Maria Mul was coördinator van de spiegelbijeenkomsten in het AMC. Inmiddels worden de spiegelbijeenkomsten in meerdere ziekenhuizen gegeven en geeft Maria Mul workshops en trainingen voor gespreksleiders.

\section{Open}

"Een spiegelbijeenkomst duurt ongeveer twee uur. Eerst zijn anderhalf uur de patiënten aan het woord. De zorgverleners en andere medewerkers die betrokken zijn bij de patiëntenzorg, zijn toehoorders. Vervolgens stellen de toehoorders verhelderende vragen. In de laatste ronde kunnen patiënten zogeheten 'individu-overstijgende vragen' stellen aan de toehoorders. Het gesprek is zo open mogelijk. De patiënten kunnen alles inbrengen waarvan zij denken dat het leerzaam is voor de afdeling of het team."

"Lang dachten we: voor we mensen naar hun ervaringen vragen moeten ze eerst uit de zorg zijn en niet meer afhankelijk van hulpverlening. Anders durven ze zich misschien niet uit te spreken. Maar uit experimenten op bijvoorbeeld de dialyse-afdeling blijkt dat mensen die nog zorg krijgen zich best durven uitspreken. Natuurlijk, als je weet dat je je dokter volgende week weer ziet, zeg je het misschien anders dan thuis bij de borrel. Maar het gaat om de inhoud, niet om de toon. En daarin worden ze niet beperkt."

\section{Meerwaarde}

"Het grote verschil met een enquête en het meest waardevol voor de zorgverleners is de directe confrontatie met patiënten, waarin zowel positieve als negatieve punten naar voren komen. Het maakt indruk als iemand je persoonlijk vertelt hoe ellendig hij zich voelde toen hij, na tien keer te hebben gehoord 'Ik kom zo', in zijn bed plaste. Dat komt veel harder aan dan wanneer je alleen de cijfers rond tevredenheid over de service van de verpleging bekijkt. Dan ben je sneller gemotiveerd om je gedrag aan te passen."

"Andere opbrengsten zijn praktische verbeterpunten. Voor een deel gaat het om quick wins. Een viltlaagje op de pedaalemmer aanbrengen, zodat deze niet meer kleppert bijvoorbeeld. Daarnaast komen er altijd duidelijke verbeterpunten voor de organisatie naar voren."

"Het is belangrijk dat van de bijeenkomsten een verslag wordt gemaakt en uit dat verslag een sterkte-zwakteanalyse wordt samengesteld en besproken. We maken dan een onderscheid in de feedback die we hebben gekregen: wat was een incident en behoeft dus geen structurele aandacht en wat trekken we ons aan? Dus wat zijn punten waarvan we zeggen: daar moeten we iets mee en daar kunnen we iets mee? Welke acties ondernemen we?"

\section{Knelpunt}

"Het opvolgen van de verbeterpunten is onderdeel van het traject, maar komt nog wel eens in de knel. Vaak zie je dat individuele medewerkers vanuit hun enthousiasme verbeterpunten aanpakken. Die moeten dan knokken om iedereen mee te krijgen. Het helpt dan enorm als het management achter hen staat en hen faciliteert. Als een verpleegkundige een verslag moet schrijven, omdat de manager geen secretaresse beschikbaar stelt, vraag je eigenlijk al teveel van de professionals. En dat ontmoedigt. Het helpt dan als de organisatie en de medewerkers beseffen dat zorgen voor kwaliteit gewoon een onderdeel van het werk is. En dat daar dus ook financiering voor nodig is." 


\section{Patiëntenmanifest}

Een patiëntenmanifest omschrijft concrete kwaliteitsnormen in de vorm van beloften waaraan de zorg voor patiënten voldoet. Die kwaliteitsnormen zijn gebaseerd op wat patiënten en zorgprofessionals zelf belangrijk vinden. Het ziekenhuis beschikt zo over een heldere kwaliteitsnorm, die organisatieveranderingen stimuleert om de beloften waar te kunnen maken. Het ziekenhuis financiert dit. Elke patiënt krijgt een exemplaar van het patiëntenmanifest zodat duidelijk is waar de patiënt op mag rekenen.

Verpleegkundige Robert Simons stond aan de wieg van het patiëntenmanifest dat het $A M C$ hanteert.

\section{Beloning}

"Patiëntgerichtheid geeft inspiratie. Uiteindelijk is er niks fijner dan een patiënt die tegen je zegt: 'Wat fijn dat u er was en dat u me geholpen heeft.' Dat is een heerlijke beloning."

\section{Beloften}

"Je kunt als ziekenhuis zeggen: 'Wij zijn er altijd voor de patiënt.' Ja, natuurlijk ben je er voor de patiënt! Maar wat betekent dat concreet? Op basis van spiegelbijeenkomsten, focusgroepen met zorgprofessionals, advies van de cliëntenraad en analyse van klachten hebben we beloften aan patiënten in het patiëntenmanifest geformuleerd."

"Het patiëntenmanifest stelt de mens achter de patiënt centraal. Dokters en verpleegkundigen zijn geneigd vanuit zichzelf te denken, te doen wat voor hen het handigst is. Tot voor kort dachten we nooit na over wat het betekent voor een patiënt als hij drie uur op een poli moet wachten voor hij aan de beurt is. Ik heb het druk, dus de patiënt moet maar wachten, denkt de arts algauw.

Nee, het moet andersom: jij moet zo plannen dat de patiënt maximaal twintig minuten moet wachten. Dat staat nu ook in het manifest."

"Voor het realiseren van de meeste beloften zijn organisatorische aanpassingen nodig. Je moet er veel partijen bij betrekken en moeilijke afwegingen maken. Dat heb ik wel onderschat. Eén van onze beloftes is: 'U krijgt uw behandeling zo snel mogelijk. Voor een oncologische operatie is dat binnen drie weken na afronding van het vooronderzoek.' Zo'n belofte brengt lastige afwegingen met zich mee en dat levert discussie op. Een operatiezaal is een schaars goed. Alles wat je de ene patiënt op basis van die belofte meer geeft, moet er bij een ander af."

"Een andere belofte is: 'Bij de planning van onderzoeken zorgen we zo veel mogelijk voor een combinatie van afspraken op dezelfde dag.' Voor die belofte moeten allerlei artsen hun agenda's openzetten, zodat de dokter die bij de patiënt aan tafel zit meteen een afspraak kan maken bij een andere afdeling. Nou ja, alles goed voor de patiënt, maar ík ga over mijn agenda!, denken veel artsen. Om zo'n belofte waar te kunnen maken moet je dus met veel mensen om de tafel. Het manifest is nu ook een leidraad bij reorganisaties. Bij de reorganisatie van de polikliniek hebben we gezegd: 'We richten onze dienstverlening helemaal in op basis van het patiëntenmanifest.'"

Bronnen

"We borgen de beloften door ze op allerlei momenten aan de orde te stellen, tijdens teamoverleg of overleg met het bestuur bijvoorbeeld. En door de resultaten te evalueren. Daarvoor halen we informatie uit verschillende informatiesystemen of we vragen het de patiënt via enquêtes."

\section{Keurmerk Seniorvriendelijk Ziekenhuis}

Het Keurmerk Seniorvriendelijk Ziekenhuis geeft informatie over welke ziekenhuizen ouderen goede zorg bieden. Het Fonds PGO betaalt de ontwikkeling van het keurmerk. Het Keurmerk biedt ouderen keuzeinformatie en verzekeraars inkoopinformatie. En het stimuleert ziekenhuizen om de zorg vanuit het patiëntenperspectief te verbeteren.

De ouderenbonden Unie KBO, PCOB, NOOM en NVOG namen het initiatief voor het Keurmerk Seniorvriendelijk Ziekenhuis. Marjolein de Booys leidt het project vanuit de Unie KBO.

\section{Knelpunten}

"De ontwikkeling van het keurmerk begon met een inventarisatie van knelpunten via literatuuronderzoek en interviews met ouderen en hun naasten.

Dat leverde een lange lijst op met knelpunten in ziekenhuiszorg voor ouderen. De achterban van de ouderenbonden heeft daar een rangorde in aangebracht. We hebben ook de zorgverleners erbij betrokken. Zij zien natuurlijk ook wat er misgaat en wat beter kan. Het resultaat is een lijst van vijftien kwaliteitsaspecten voor de organisatie van zorg voor ouderen, toegankelijkheid en fysieke inrichting."

"90 Procent van de Nederlandse ziekenhuizen wilde het keurmerk krijgen. Speciaal getrainde senior scouts gingen als mystery guest naar de ziekenhuizen om de fysieke omgeving te beoordelen. Ook zijn er vragenlijsten uitgezet over de wijze waarop de zorg aan ouderen is georganiseerd. Het keurmerk wordt toegekend aan ziekenhuizen die voldoen aan de normering. Die normering kan elke ronde strenger worden, zodat ziekenhuizen gemotiveerd blijven om te verbeteren." 
Wankel evenwicht

"Het ontwikkelen van het keurmerk is nodig omdat iets helemaal niet goed gaat in de zorg voor ouderen. Eén op de drie ouderen gaat slechter het ziekenhuis uit dan erin. Dat komt meestal niet door de operatie of de aanleiding waarom de oudere is opgenomen, maar door het beleid in het ziekenhuis en de nazorg. Een ziekenhuisopname brengt de oudere ineens in een wankel evenwicht.

Als je daar niet goed op inspeelt, kan er van alles misgaan, zoals is gebleken uit onderzoeken van onder andere de KNMG, de Gezondheidsraad en de Inspectie voor de Gezondheidszorg."

"Ziekenhuizen spelen daar al op in, bijvoorbeeld door zeventigplussers te screenen op risicofactoren, zoals vallen, ondervoeding, fysieke beperkingen en delier. Die screening is een indicator van de Inspectie. Het keurmerk gaat een stap verder: we vragen ziekenhuizen protocollen op te stellen die antwoord geven op de vraag: wie gaat wat doen als welke risicofactoren zijn geconstateerd? Een ander belangrijk criterium van het keurmerk is dat een ziekenhuis een geriatrieteam moet hebben met minimaal een klinisch geriater of internist ouderengeneeskunde en een geriatrieverpleegkundige."

\section{Continuïteit}

"Wat uit de interviews naar voren kwam en wat ik echt heel schokkend vond, is dat de huisarts bij de nazorg eigenlijk geen rol speelt. Dit komt onder meer omdat de huisarts veel te laat wordt geïnformeerd. Dus we hebben ook kwaliteitscriteria opgesteld over de continuïteit van zorg, zoals tijdige informatieoverdracht en de patiënt binnen een week na ontslag bellen om te vragen hoe het gaat."

"Een andere eyeopener was: als je een oudere van 65 jaar die verder gezond is tien dagen in een ziekenhuisbed laat liggen, treedt er een functieverlies op dat gelijk is aan vijftien jaar veroudering! Gewoon in bed liggen en niet actief zijn, is al foute boel voor een oudere. Dus daar moeten ziekenhuizen beter op inspelen. Eén van de kwaliteitscriteria is gericht op het activeren en laten participeren van ouderen."

"Het Keurmerk Seniorvriendelijk Ziekenhuis levert keuzeinformatie op voor patiënten en zorgverzekeraars. Maar een belangrijk doel is natuurlijk vooral dat het ziekenhuizen stimuleert om kritisch te kijken naar de zorg voor senioren, dat ze zichzelf de vraag stellen: hoe seniorvriendelijk zijn wij eigenlijk, qua zorg en inrichting? Dat triggert ziekenhuizen om hun beleid aan te passen. Patiëntgerichte zorg realiseer je niet van de ene op de andere dag. Dat heeft een zetje nodig."

\section{Patiënt Journeys}

Patiënt Journeys brengt in kaart hoe patiënten het zorgproces ervaren en laat zien welke twee of drie momenten écht het verschil maken in hun beleving. De methodiek laat ook zien waarin het loont om wel of niet te investeren. Patiënt Journeys wordt als methodiek aangeboden door bureau Altuïtion.

Partner Edward Huizenga van Altuïtion heeft een achtergrond in het bedrijfsleven en past Patiënt Journeys toe in de zorg.

Emotie

"Hoe mensen dienstverlening ervaren wordt vooral bepaald door hun herinnering aan hun meest positieve of negatieve emoties tijdens het dienstverleningstraject. Met name de piekmomenten en de laatste momenten blijven hangen. Wanneer je inzicht hebt in die essentiële momenten, kun je het proces vanuit die invalshoek verbeteren."

"In het bedrijfsleven wordt al veel gewerkt met het inrichten van processen vanuit beleving en emotie. Voor de medische wereld is het nog redelijk nieuw. Vee medische processen zijn ingericht vanuit een (technisch-) medisch perspectief. $E r$ is weinig bekend over de emoties van de patiënt. Patiëntentevredenheid meet de huidige situatie. Ze leveren vaak een hele rits aan verbeterpunten op die je niet allemaal kunt uitvoeren. Patiënt Journeys brengen in kaart welke twee of drie momenten écht het verschil maken. Door daar goed op in te spelen kun je de hele relatie met de patiënt naar een hoger niveau brengen."

\section{Emotiecurve}

"Patiënt Journeys is een gestructureerde methode. We brengen eerst alle processtappen en contactmomenten in het medische proces in kaart. Vervolgens interviewen we twaalf tot zestien patiënten in gesprekken van circa 2,5 uur. In zo'n gesprek gebruiken we psychologische opdrachten, waardoor we zicht krijgen op de diepste emoties van de patiënt. Met die interviews hebben we 70 tot 80 procent van de gemeenschappelijke drijfveren van patiënten te pakken. Daarmee kunnen we een 'emotiecurve' maken die de momenten van negatieve en positieve emoties inzichtelijk maakt. Op basis van die emotiecurve zie je waar en hoe je de positieve momenten kunt creëren en hoe je het zorgproces positief kunt beëindigen."

"Inspelen op de momenten van negatieve en positieve emoties zit vaak in kleine dingen en niet in grote innovaties. Mensen die net uit een operatie komen zijn bijvoorbeeld vaak erg angstig en onzeker. Als je dat begrijpt, kun je daarop inspelen en die beleving verbeteren. In veel ziekenhuizen vertelt een verpleegkundige hun hoe de operatie is verlopen. Maar het maakt veel meer indruk en geeft patiënten een veel positiever gevoel wanneer de chirurg die de 
operatie zelf heeft uitgevoerd dat doet. Zo'n kleine aanpassing draagt aantoonbaar bij aan een hogere patiënttevredenheid, dat kun je bijvoorbeeld aantonen met CQ-scores."

\section{Medewerkers}

"We werken daarnaast ook met de emotiecurve van medewerkers. Hoe vinden zij dat ze het zorgproces uitvoeren? Vaak is dat het verhaal van het kleine poesje dat in de spiegel kijkt, een leeuw ziet en denkt: goh, wat zijn wij toch goed bezig. Dat zijn ze natuurlijk ook, alleen sluit hun zelfbeeld niet aan bij het beeld van de patiënt. Medewerkers zijn - uiteraard goedbedoeld - vaak gericht op medisch handelen. Door de confrontatie met de Patiënt Journeys zien ze dat ze ook echt invloed hebben op de beleving van patiënten."

\section{Narratief onderzoek}

Narratief onderzoek is een onderzoekstraject om invulling te geven aan het begrip 'samen kiezen voor beter' vanuit het perspectief van patiënten en professionals. De kosten komen voor rekening van het ziekenhuis en het resultaat is inzicht in het perspectief van patiënten en professionals over patiëntgerichte zorg. Bovendien levert het suggesties voor concrete verbeteracties die de patiënt meer centraal stellen in het ziekenhuis.

\section{Merel Visse en Mechteld van der Westen verrichtten in het VU medisch} centrum in 2012 een narratief onderzoek in twee trajecten, ziekenhuisbreed en op de afdeling Cardiologie.

\section{Integratie}

"'Patiëntparticipatie' en 'patiënt centraal' staan hoog op de agenda binnen het ziekenhuis. Maar wat betekenen die begrippen nou eigenlijk voor mensen? In het onderzoekstraject werken we in verschillende sessies met medewerkers en patiënten naar een gezamenlijke visie op invloed en keuze; twee begrippen die in het ziekenhuis regelmatig de revue passeren. Eerst in homogene groepen van patiënten en professionals afzonderlijk. Zo kunnen patiënten in een veilige setting uitvinden wat ze belangrijk vinden en wat ze willen inbrengen in het gesprek met professionals. Pas dan kun je de dialoog aangaan. Ook met professionals worden afzonderlijke sessies gehouden. Alleen aandacht voor het patiëntenperspectief is te beperkt: zorg vindt plaats in de relaties die patiënten met zorgverleners aangaan. Patiënten hebben ervaringskennis, maar zorgverleners hebben evengoed ervaringskennis, dus het gaat heel erg om het verbinden van al die soorten kennis met elkaar. In een dialoogbijeenkoms komen medewerkers en patiënten samen om hun perspectieven te integreren."

\section{Concreet}

"Tijdens de sessies vragen we patiënten en zorgverleners voorbeelden te noemen van situaties waar ze invloed en keuze ervaren - of juist niet. Dat doen we per fase in het zorgproces. Je kunt heel direct vragen: wat verstaat $u$ onder keuze of invloed? Maar dat is een abstracte vraag, die staat ver af van de concrete, dagelijkse ervaring, van iemands leefwereld. Als je vraagt: 'Vertel eens van een moment dat je het idee had dat je een keuze had' gaan mensen vertellen over die ervaring. We stimuleren mensen om dat heel episodisch te vertellen. Je moet het als het ware voor je kunnen zien als in een film. De verwachting is dat ze dan ook allerlei dingen vertellen waarvan ze niet weten dat ze deze weten. Die verhalende ervaringen van mensen bevatten stilzwijgende kennis, die je zo naar voren haalt en waar je vervolgens wat mee kunt."

\section{Analyse}

"Na de homogene sessies hebben we een thematische analyse uitgevoerd. We hebben gekeken welke thema's in afzonderlijke fasen van het zorgproces terugkeren. Daar kwamen drie hoofdgebieden uit met diverse subgebieden. Het eerste gebied is een 'wederkerige zorgrelatie', het tweede 'samen keuzes maken in de behandeling' en de derde 'informatie, tijd en logistiek'. De thema's die we vonden sloten aan bij literatuur over bijvoorbeeld shared decisionmaking. Maar we kwamen ook nieuwe thema's tegen."

\section{Verbeteringen}

"Tijdens de heterogene afsluitende sessie, de dialoogsessie, hebben we hele concrete verbeteringen besproken met degenen die betrokken waren bij het project. Bijvoorbeeld: faciliteer middels het elektronisch patiëntendossier een standaardstappenplan en een checklist, die online staat en uit te printen is voor mensen. Patiënten hebben er behoefte aan dat het proces heel inzichtelijk wordt: "Ik heb vandaag met de dokter gesproken, wie spreek ik volgende week? Kan ik daarna nog een uitkomst van een onderzoek verwachten en zo ja, wanneer? Door wie wordt dat teruggekoppeld of moet ik zelf terugbellen?" Echt op detailniveau. Om die verbeteracties te borgen heb je echt draagvlak, commitment en budget nodig. Dat kun je al opbouwen door medewerkers heel vroeg bij het project te betrekken. Dat is ook een nevendoel van de sessies met professionals."

"De inzichten die we hebben verworven hebben wellicht ook betekenis voor andere ziekenhuizen. Toch denk ik dat narratief onderzoek in iedere instelling opnieuw plaats kan vinden. Kennis is vaak context-, tijd- en plaatsgebonden. Er zijn overal nieuwe of andere spanningsvelden waarin kennis ontstaat en betekenis krijgt." 


\section{Menslievende zorg}

Het St. Elisabeth Ziekenhuis in Tilburg heeft samen met de Universiteit van Tilburg het programma Menslievende zorg ontwikkeld. Het programma beoogt patiënten kwaliteit van zorg te laten ervaren en de arbeidsvreugde var zorgprofessionals te verhogen. In 'leergemeenschappen' komen zorgprofessionals samen om te onderzoeken wat zorg tot goede zorg maakt en hoe zij daaraan in hun dagelijks werk vorm kunnen geven. Het programma krijgt subsidie uit verschillende fondsen. Daarnaast zijn er 250 donateurs die maandelijks een bedrag storten. Door het inzetten van leergemeenschappen wordt een cultuuromslag gecreëerd waardoor de relatie tussen patiënt en zorgprofessional menslievender wordt.

Rita Arts is zorggroepmanager bij het St. Elisabeth ziekenhuis. Zij stond aan de wieg van het programma Menslievende zorg.

\section{Relatie}

"We focussen als zorgprofessionals vaak op het technisch handelen. Daarvoor hebben we richtlijnen - evidence based en allemaal op en top in orde. Maar de patiënt echt horen, daar kunnen we nog veel over leren. Je kunt een heel goede dokter zijn, maar als jij niet kan áánsluiten bij je patiënt, heb je voor de helft verloren. De relatie met de patiënt is de kern van ons vak en de passie van zorgprofessionals. Maar met de focus op efficiency is dat de laatste jaren in de verdrukking gekomen. Zonder de efficiency aan te tasten de intermenselijke relatie weer centraal stellen: daarom draait het programma Menslievende zorg."

\section{Vuur}

"ledere zorgprofessional werkt in het ziekenhuis vanuit een bepaalde betrokkenheid. Sommigen zitten nog vol vuur, bij anderen is het een waakvlammetje geworden. Maar het vuur is er altijd. Je moet het alleen wel met de juiste randvoorwaarden blijven voeden."

\section{Leergemeenschappen}

"Verandering moet uit de mensen zelf komen, niet van bovenaf. Daar zetten wij de 'leergemeenschappen' voor in. In een leergemeenschap gaan professionals met elkaar in gesprek over hun ervaringen en reflecteren hierop. Ze praten over zaken als: wat maakt zorg tot goede zorg? Waar sloegen we de plank mis? Zo komen ze tot oplossingen: dát moeten we anders inrichten of doen."

"Professionals voelen zich vaak vastzitten in systemen. Systemen die hen niet faciliteren, maar tegenwerken. Je moet dus in die systemen iets veranderen. Maar vaker nog gaat het om bewustwording. Wat betekent het bijvoorbeeld voor een patiënt als je je pieper niet afgeeft en gestoord wordt tijdens een slechtnieuwsgesprek? Professionals in de gezondheidszorg zijn vaak doeners. Ze denken veel in goed en fout. Maar het gaat niet om de vraag wie wanneer en waar heeft gefaald, maar om de oplossing: wat kunnen we ervan leren?"

\section{Onderzoek}

"De gesprekken in de leergemeenschappen kunnen ook aanleiding zijn voor een klein onderzoek. Zorgprofessionals observeren dan de zorg in de praktijk, interviewen patiënten of familieleden of analyseren klachten. Geluidsoverlast is bijvoorbeeld een probleem dat veel patiënten noemen. Twee verpleegkundigen zijn daarop in een patiëntenkamer gaan zitten en hebben alles opgeschreven wat ze horen. Wat er over patiënten gezegd wordt aan de balie, de onenigheid, de telefoongesprekken die je letterlijk op een patiëntenkamer kunt volgen. Die inzichten koppelden ze terug naar hun teams. Dat maakt dat zo' $n$ team zich daarvan bewust wordt en het anders gaat doen."

\section{Privacy}

"In de leergemeenschap oncologie was onder andere de privacy van patiënten onderwerp van gesprek. Wanneer een patiënt wordt opgenomen, biedt alleen het kastje naast zijn bed hem eigenlijk privacy. Daar kan hij spulletjes in kwijt, dat is van hem. Daar zijn we ons als zorgprofessionals helemaal niet meer van bewust. Als verpleegkundigen ruk je zo een kastje open om even een pyjama te pakken. Daarin handel je gewoon. Maar het is zo'n kleine moeite om dat in overleg met de patiënt te doen: 'Mag ik in uw kastje? Waar heeft u die spulletjes liggen? Wat wilt u...?' Daarmee geef je de patiënt veel privacy terug. Dat inzicht breng je terug in het team. Dan spreek je af: laten we dit gewoon doen en elkaar er ook op aanspreken."

\section{De lastige patiënt}

"De leergemeenschap rondom neurologie koos als thema 'de lastige patiënt'. In deze casus zag je dat de verpleegkundigen en artsen alsmaar harder gingen lopen om de familie tevreden te stellen. En dat ze alsmaar de dingen deden die niet aansloten bij de verwachtingen van die familie. De familie moest leren omgaan met het veranderde gedrag van de patiënt die een beroerte had.

Dat leverde spanningen op. Hoe krijg je die twee werelden nou goed bij elkaar? Het team stond uitvoerig stil bij de klacht van de patiënt en zijn familie, door diepte-interviews met deze mensen en door hierop te reflecteren als team.

Nu zie je dat het team daarvan heeft geleerd, dat het snel signaleert: daar gaan we weer, niet doen! Terug naar de familie, stel de vraag: 'Wat verwachten jullie? Dit soort veranderingen vraagt een lange adem, maar langzaam zie je echt een cultuurverandering ontstaan." 


\section{Els Borst-gesprekken}

Tijdens zogeheten Els Borst-gesprekken vertellen kankerpatiënten hun ervaringen aan artsen en verpleegkundigen. De patiënten en de zorgprofessionals die deelnemen aan de gesprekken, hebben geen zorgrelatie met elkaar. De Els Borst-gesprekken zijn ontwikkeld met geld van de Muntendamprijs, die Els Borst als voorzitter van de Nederlandse Federatie Kankerpatiëntenorganisaties (NFK) kreeg. Zorgverzekeraar Menzis financiert de gesprekken in ziekenhuizen die het Menzis-predicaat TopZorg 2013 voor darmkanker en/of prostaatkanker willen hebben. Andere specialismen en ziekenhuizen kunnen de gesprekken op eigen kosten inzetten. Het belangrijkste doel van de gesprekken is (meer) bewustwording van artsen en verpleegkundigen over communicatie en bejegening.

Veertig ziekenhuizen met Topzorg darm- en/of prostaatkanker hebben in 2013 Els Borst-gesprekken gehouden. Ook hebben gesprekken plaatsgevonden met andere groepen kankerpatiënten. De NFK ontwikkelt en implementeert de Els Borst-gesprekken. NFK-medewerkster Carin Hoogstraten is hierbij nauw betrokken.

Onafhankelijk

"We hebben er bewust voor gekozen dat zorgverleners en patiënten elkaar nie kennen voor het gesprek. Patiënt en arts hebben een afhankelijkheidsrelatie.

Daar wilden we de patiënten uithalen, zodat ze echt vrij kunnen praten over wat ze hebben meegemaakt. Patiënten praten dus over zorgverleners in andere ziekenhuizen. Desondanks voelen zorgverleners zich aangesproken. 'Oh! Dat doe ik ook wel eens! Ik had me nooit gerealiseerd dat dat zo over kan komen.' Dat werkt heel sterk."

\section{Blauwdruk}

"We willen dat zorgverleners bewuster omgaan met patiënten en hun naasten. De werelden van de zorgverlener en de patiënt schuren langs elkaar heen. Artsen willen graag een soort blauwdruk: zo moet ik met een patiënt omgaan. Maar er is nooit sprake van dé patiënt; patiënten zijn allemaal individuen die onderling sterk verschillen in hun behoeftes. Bovendien heeft een patiënt in verschillende fases ook andere behoeftes. De zorg en de communicatie daarover daarop afstemmen: daarover gaan de Els Borst-gesprekken."

"Bij een van de gesprekken zei de ene patiënt: 'Ik wil heel veel informatie.' Maar een ander had daar helemaal geen behoefte aan. De arts zat daar echt met de handen in het haar: 'Wat willen patiënten dan? Hoe kom ik erachter of ze veel of weinig info willen?' Het antwoord is simpel: vráág gewoon wat de patiënt wil."
Impact

"Een ander belangrijk thema is de impact die de diagnose kanker heeft. Alleen al het horen van de zin: 'U heeft kanker', is erg ingrijpend. Daar gaat het vaak al mis in de communicatie. De arts wil meteen de behandelopties bespreken: 'Nou, we kunnen dit doen, we kunnen dat doen.' Terwijl we weten dat mensen die de diagnose horen gewoon geen nieuwe informatie meer kunnen opnemen."

"Zorgprofessionals zijn goed getraind op het gebied van communicatie. Zij hebben die vaardigheden. Maar als je gewoon aan het werk bent, ben je je niet altijd bewust van wat je zegt en wat dat betekent voor de persoon tegenover je. In de Els Borst-gesprekken zeggen patiënten dan: 'Ik hoorde niks meer van wat die arts zei. Ik dacht: moet ik nu mijn begrafenis regelen?'"

\section{Verwachtingen}

"Het gaat ook over verwachtingsmanagement. Een verpleegkundige zat met het gevoel dat zij mensen tekortdeed. Door de drukte kon ze nooit eens even bij een patiënt gaan zitten. Eén van de patiënten zei: 'Maar dat verwacht ik ook helemaal niet van je. Ik verwacht wel dat je me even aankijkt als je die infuuspomp verwisselt.' Je zag gewoon de spanning uit die verpleegkundige wegvloeien."

"Artsen die moeite hebben met communicatie komen waarschijnlijk helemaal niet in dit soort gesprekken terecht. Dat probleem kunnen we met een Els Borstgesprek ook niet oplossen. Maar empathische artsen en verpleegkundigen worden door deze gesprekken nog beter in hun vak. Ik hoop dan ook dat ziekenhuizen deze gesprekken regelmatig organiseren, ook voor patiënten met andere soorten kanker." 


\section{Experience Based Co-Design (EBCD)}

In Experience Based Co-Design (EBCD) leveren ervaringen van zorgprofessionals én patiënten input om het zorgproces te verbeteren. Eerst inventariseren afzonderlijke focusgroepen van patiënten en zorgprofessionals verbeterpunten. Daaruit selecteert een gezamenlijke focusgroep de vier of vijf belangrijkste. Ten slotte werken co-designgroepen van professionals en patiënten de verbeterpunten uit. De klankbordgroep en de cliëntenraad van het ziekenhuis zijn betrokken bij het project en meten de resultaten. Het ziekenhuis staat garant voor de kosten. Uniek aan EBCD is dat patiënten samen met zorgverleners ook nauw betrokken zijn bij de prioritering en uitwerking van de verbeterpunten.

$E B C D$ is in het Sint Lucas Andreas Ziekenhuis in Amsterdam ingevoerd in het kader van een $\mathrm{CBO}$-project dat werd gefinancierd vanuit een innovatiefonds. De methode is toegepast op de dagbehandeling en polikliniek van de afdeling hematologie/oncologie. Verpleegkundig specialist Peggy den Hartog is als projectleider betrokken bij het EBCD-project.

\section{Benadering}

"Via patiënttevredenheidsonderzoeken en spiegelbijeenkomsten besteden we veel aandacht aan wat patiënten van ons ziekenhuis vinden. Maar vervolgens verzinnen wij zelf welke verbeteringen we waar en hoe zullen realiseren.

Daardoor weten we nooit precies of we wel de juiste verbeteringen doorvoeren EBCD biedt ons die mogelijkheid wel."

"In de focusgroepen probeerden we steeds een sfeer te creëren waarin de input van de patiënt net zo belangrijk is als die van de dokters. Dat is gelukt. Tijdens de bijeenkomsten waren artsen, patiënten, verpleegkundigen en poli-assistenten echt gelijkwaardig. Een extra uitdaging was het om migranten en ouderen erbij te betrekken, die immers een belangrijk deel van onze patiëntenpopulatie vormen. De sleutel bleek een persoonlijke benadering. Het werkt goed als iemand die de patiënt al kent rustig uitlegt wat het project inhoudt en hem persoonlijk uitnodigt om deel te nemen. Uiteraard is het ook belangrijk om mensen in hun waarde te laten. Bijvoorbeeld door ze op een open manier te vragen hoe zij informatie willen ontvangen en hen meer mogelijkheden te bieden dan alleen e-mail. Mensen krijgen dan niet het gevoel: iedereen heeft een computer, behalve ik."

\section{Informatievoorziening}

"Als je samen met patiënten verbeterpunten uitwerkt, kom je tot nieuwe inzichten. Bijvoorbeeld over de informatievoorziening. Mensen krijgen altijd een heel pakket met informatie over chemotherapie of immunotherapie. Maar ze krijgen geen informatie over tandartsbezoek tijdens hun behandeling. Ze stellen zich vragen als: 'Mag ik wel naar de tandarts? Heb ik dan andere antibiotica nodig?
Wanneer zijn de bloedwaardes hoog genoeg om te gaan?' Die informatie geven we nu dus ook. Uit de co-designgroepen bleek bijvoorbeeld ook dat mensen behoefte hebben aan informatie over problemen met een kunstgebit. Wij dachten, daar hoef je geen informatie over op te nemen, want dat is nooit een probleem. Maar mensen waren daar toch onzeker over, dus nu hebben we die informatie toegevoegd."

\section{Emotional mapping}

"Emotie is belangrijk bij EBCD. In de focusgroepen passen we de techniek emotional mapping toe. Daardoor horen we het verhaal van de patiënt áchter het verbeterpunt. Dat maakt indruk. Als je in een patiënttevredenheidsenquête een cijfer 4 scoort op het onderdeel hygiëne is dat erg. Maar bij emotional mapping hoor je wat zoiets echt voor mensen betekent. Dan zegt een patiënt: 'Dan ben ik al moe van de chemo en dan moet ik boven de pot gaan hangen, omdat het toilet niet schoon is. Als ik klaar ben laat ik het toilet niet schoon achter... Dan voel ik me heel vervelend en bezwaard, want die mevrouw die na mij gaat zal wel denken: dat is ook een vies mens dat je er zo naast plast.' Als je dat hoort; voel je de impact die het heeft op de patiënt en ben je veel meer gedreven om het probleem ook echt op te lossen."

\section{Betrokkenheid}

"EBCD dwingt je als het ware om als afdeling verbeterpunten ook echt aan te pakken. Daar gaat het bij andere methoden namelijk vaak mis. Bij EBCD is de betrokkenheid van je patiënten bij de uitwerking van de verbeterpunten een soort stok achter de deur. Het is een intensief traject, zeker ook voor patiënten. Maar wel zeer waardevol." 


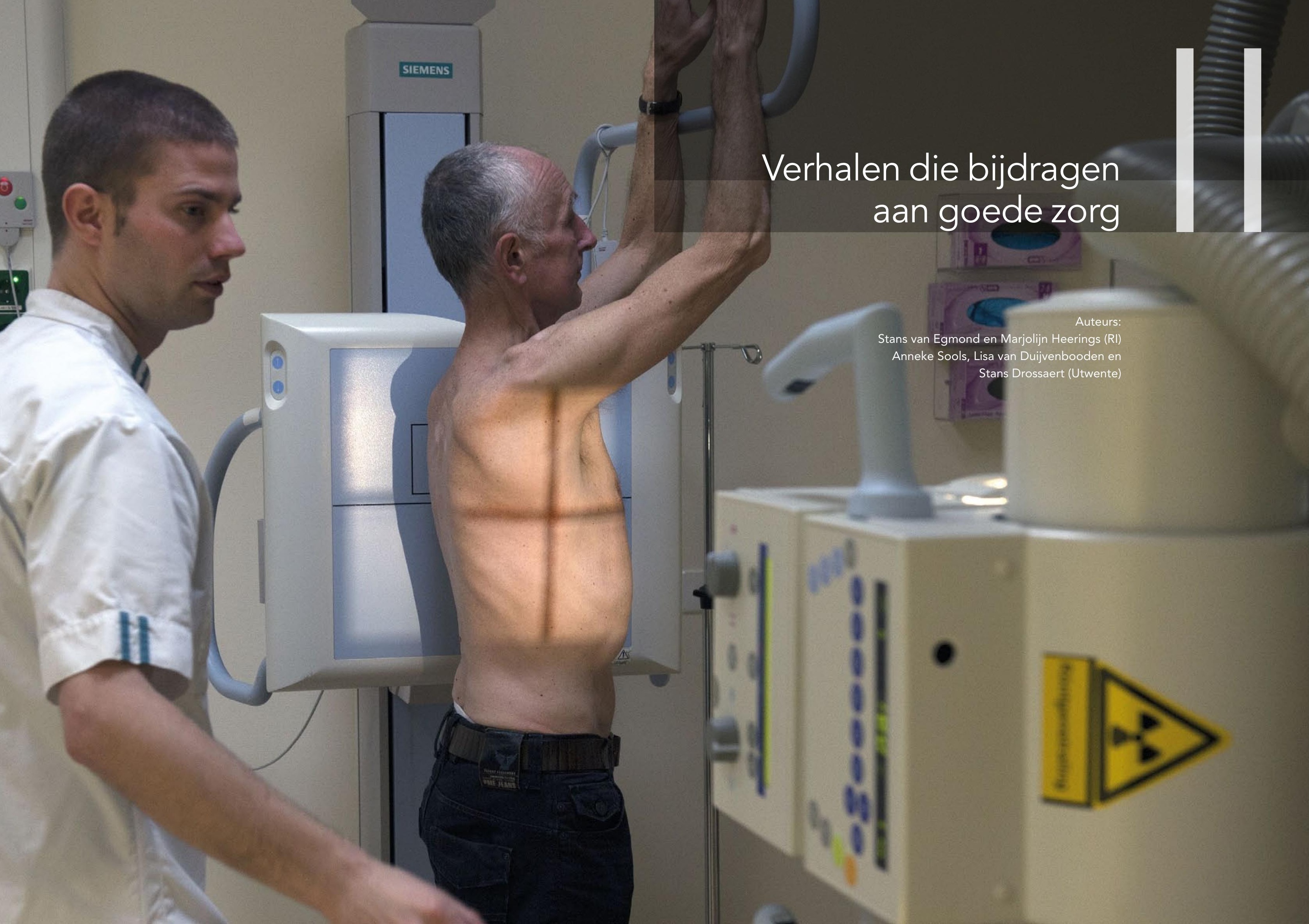




\section{Methoden}

In deel II bespreken we het onderzoek en de resultaten die uit alle onderdelen naar voren zijn gekomen. In dit hoofdstuk volgt eerst een korte introductie van alle onderdelen van het onderzoek en in paragraaf 2 een uitgebreidere bespreking van de verhalende methode in het bijzonder. Een compleet verslag is te vinden in de digitale bijlagen. Vervolgens maken we in paragraaf 3 kennis met de 103 auteurs van de verhalen.

Hoofdstuk 4 beschrijft de negen ervaringstypen die uit de verhalen naar voren zijn gekomen en de reactie daarop van de zorgverleners in workshops. In de hoofdstukken 5 tot en met 8 worden de vier thema's (1) Onzekerheid of angst in een onbekende situatie, (2) Moeizame waardering van mondige en actieve patiënten (3) Onmondig in het ziekenhuissysteem, en (4) Onbekende verwachtingen - bij patiënt én zorgverlener, besproken die uit het gehele onderzoek naar voren zijn gekomen en die een rol spelen bij de manier waarop mensen vorm geven aan autonomie en mondigheid in het ziekenhuis. De thema's kunnen mondigheid ook belemmeren, en dus ook goede zorg in de weg staan. Hoofdstuk 9 eindigt met conclusies en een herhaling van de aanbevelingen.

\subsection{Onderzoeksopzet}

\section{Onderzoeksvragen}

Patiënten zijn de laatste jaren mondiger geworden. De overheid doet een steeds groter beroep op de mondige patiënt, ingegeven door verschillende (beleids)ontwikkelingen. Tegelijkertijd klinkt er veel kritiek op het beroep dat de overheid doet op deze mondige patiënt. Er bestaan goede systematische redenen waarom het beroep dat door de overheid wordt gedaan op de mondige patiënt maar moeizaam vorm lijkt te krijgen in het ziekenhuis. Deze tegengestelde bewegingen vormen het uitgangspunt van dit onderzoek. Het doel is inzicht te krijgen in hoe de rol van de mondige patiënt in ziekenhuizen op dit moment vorm krijgt en hoe de ervaringen van patiënten kunnen bijdragen aan verbetering van kwaliteit van zorg. Dat heeft geleid tot de volgende onderzoeksvragen:

1. Hoe ervaren patiënten en hun naasten verleende ziekenhuiszorg?

2. Wat zeggen deze ervaringen over de rol van de patiënt in het zorgproces?

3. Hoe kunnen deze ervaringen bijdragen aan het verbeteren van de kwaliteit van ziekenhuiszorg?

\section{Onderzoeksmethoden}

We hebben deze vragen onderzocht via een aantal kwalitatieve methoden. Allereerst is een narratieve methode gebruikt. Via het verzamelen en analyseren van geschreven ervaringen is onderzocht hoe mensen ziekenhuiszorg ervaren via een verhaallijnenanalyse, en is een thematische analyse van de verhalen uitgevoerd om inzicht te krijgen in de betekenis die mensen geven aan kwaliteit van zorg.

We hebben gekozen voor verhalen van patiënten over hun ervaringen met de zorg als eerste bron van materiaal, omdat verhalen een belangrijke, maar onderbenutte bron van kennis vormen om de zorg te verbeteren. Onder invloed van democratiseringsbewegingen in de zorg waarbij patiënten een steeds grotere rol kregen, die ook wettelijk in rechten werd vastgelegd, wordt de stem van de patiënt steeds belangrijker geacht. Deze stem wordt echter niet vaak via verhalen in kaart gebracht. Verhalen geven weliswaar geen inzicht in de feitelijke stand van zaken van het zorgsysteem van Nederland anno 2013, maar bieden wel de mogelijkheid zo gedetailleerd en rijk mogelijk inzicht te krijgen in de manieren waarop patiënten de zorg ervaren, wat ze belangrijk vinden, welke zaken hen aan het hart gaan en welke zaken onopgemerkt blijven (Tsianakas et al 2012).

Vervolgens zijn vier workshops georganiseerd met artsen, verpleegkundigen en patiëntenverenigingen waarin steeds een aantal ervaringen is voorgelegd aan de deelnemers. Het doel van deze workshops was om inzicht te krijgen in hoe zorgprofessionals in het algemeen aankijken tegen patiëntenervaringen en hoe zij aankijken tegen een aantal specifieke ervaringen uit het onderzoek.

Daarnaast zijn in april en mei 2013 gerichte interviews gehouden met stakeholders uit het veld, onder meer met de Artsenfederatie KNMG, de Orde van Medisch Specialisten (OMS), de beroepsvereniging voor Verpleegkundigen en Verzorgenden Nederland (V\&VN), de Nederlandse Vereniging voor Ziekenhuizen (NVZ), het Kwaliteitsinstituut Zorg in oprichting, de Chronisch Zieken en Gehandicapten Raad (CG-Raad) en het CBO (Centraal BegeleidingsOrgaan; adviesorgaan voor de gezondheidszorg, onderdeel van TNO). We hebben aan hen de vragen voorgelegd wat zij doen met patiëntenervaringen en hoe dat vorm krijgt, en hoe zij aankijken tegen de rol van patiënten in de zorg.

Ook is een inventarisatie gemaakt van de formele en informele manieren waarop patiënten tot juni 2012 inspraak hadden in ziekenhuiszorg en is onderzoek gedaan naar visies van artsen op mondigheid en patiëntenparticipatie via een analyse van artikelen in drie medische tijdschriften.

\section{Onderzoekslocatie}

We hebben gekozen voor het ziekenhuis als locatie van het onderzoek. Het ziekenhuis is een socio-technische, complexe omgeving waarin de verschillende perspectieven, die van de patiënt, die van de zorgverleners en die van de overheid, in elk consult lijken samen te komen. Bovendien hebben veel mensen uit 
alle lagen van de bevolking ervaring met ziekenhuiszorg en sluit het ziekenhuis als locatie voor onderzoek aan bij eerdere onderzoeken van het Rathenau Instituut naar medische technologie en autonomie in de zorg.

\section{Website}

De ervaringen zijn verzameld via een website, www.patientenwetenbeter.nl. Mensen konden op de website inloggen in het onderzoeksmenu. Daarin kon men met naam en toenaam of juist anoniem de ervaring met een ziekenhuis delen. Om ervoor te zorgen dat verhalen zo 'verhalend', rijk en compleet mogelijk zouden worden, hebben we op de website gerichte instructies gegeven. Mensen konden hun ervaring plaatsen in de vorm van een brief, met een titel, een ontvanger en een afzender. We vroegen de auteurs om een aanhef te formuleren (een titel en ontvanger) om meer informatie te krijgen over de geadresseerde aan wie ze de brief wilden richten. Verder vroegen we de schrijvers naar concrete, gedetailleerde gebeurtenissen en situaties in plaats van naar algemeenheden. De schrijvers moesten de ervaring duiden als positief, negatief of als een combinatie van beide (ambivalent) en aangeven welke elementen daaraan bijdroegen. Daarnaast hebben we mensen gevraagd om een afsluitende wens te doen over welke verbetering van de zorg de schrijvers voor ogen hadden met hun verhaal. Zo kregen we meer inzicht in wat voor mensen echt belangrijk is als het gaat om goede kwaliteit van zorg. We hebben mensen gevraagd deze onderdelen aan te vullen met gegevens over het opleidingsniveau, het soort ziekenhuis en soort aandoening waarvoor men in het ziekenhuis moest zijn. De brieven konden tussen 200 en 2.000 woorden lang zijn.

\section{Verhalen zoeken}

Om aan verhalen te komen zijn alle Nederlandse ziekenhuizen benaderd per e-mail en daarna telefonisch met de vraag of informatie over het onderzoek verspreid mocht worden door middel van een folder. Daar reageerde ruim een derde van alle ziekenhuizen positief op. Ook zijn alle Nederlandse patiëntenverenigingen meerdere keren aangeschreven met de vraag of ons onderzoek onder de aandacht gebracht mocht worden via de website of via het ledenblad. Daarna hebben we een aantal advertenties geplaatst in huis-aan-huisbladen en in een aantal landelijke dagbladen. Ook zijn oproepen geplaatst op meer dan 100 ziekte gerelateerde internetfora. Dat heeft in dertien maanden tijd in totaal 109 verhalen opgeleverd (dat betekent dat circa $1 \%$ van het totaal aantal van 10.000 bezoekers aan de website een verhaal indiende).

\subsection{Onderzoeksmethode: de opzet van de narratieve analyse} Het Levensverhalenlab van de Universiteit Twente heeft de verhalen geanalyseerd, waarbij is gezocht naar elementen die bijdragen aan het tot stand komen van een bepaalde ervaring. De verhalende benadering is bij uitstek geschikt om te achterhalen wat emotioneel én moreel op het spel staat als het om gezondheid gaat (Kleinman \& Seeman 2000; Korte et al. 2012; Sools 2010, 2013) en om dilemma's in kaart te brengen die eigen zijn aan gezondheidsproblematiek
(Radley \& Billig 1996). Gedrag of meningen van mensen zijn niet altijd logisch te verklaren, zeker niet wanneer ziekte en gezondheid op het spel staan. Voor de verteller is het verhaal een manier om gebeurtenissen te begrijpen. De verhalende methode is geschikt om unieke, particuliere en gedetailleerde kennis te vergaren die bovendien contextgebonden is. Daarmee biedt de verhalende methode ruimte aan de ambiguïteit en complexiteit van ziekenhuiservaringen. Dat levert kennis op waarmee ziekenhuizen hun voordeel kunnen doen: bijvoorbeeld over hoe een wenselijke inrichting van zorgprocessen eruit kan zien, hoe beter geluisterd kan worden naar de patiënt, en hoe beter om te gaan met diens wensen en angsten. Daarvoor zijn een verhaallijnenanalyse en een thematische analyse gebruikt.

\section{De vijf elementen van een verhaal}

Voor dit onderzoek is de verhaallijnanalysemethode van Burke gebruikt (Burke 1969; Bruner 1990; Sools 2010). Deze wordt gebruikt om inzicht te krijgen in de rijkdom, particulariteit en dynamiek binnen een verhaal. Deze methode beschouwt een ervaring als een verhaallijn met vijf samenhangende verhaallijnelementen:

1. Setting/locatie (waar speelt het verhaal zich af?)

2. Karakters (wie spelen een rol in het verhaal?)

3. Handelingen/gebeurtenissen (wat wordt gedaan of wat gebeurt er?)

4. Doelen/intenties (waartoe leidt het verhaal; motiveren de intenties (on) bewust de handelingen?)

5. Middelen/helpers (waarmee worden de gevreesde of gewenste doelen al dan niet bereikt?)

Een verhaallijn wordt gekenmerkt door spanning die wordt opgewekt door het doorbreken van het vanzelfsprekende of verwachte, ook als de spanning niet expliciet wordt genoemd door de schrijver. De spanning zet het verhaal in beweging en maakt het verhaal interessant voor de lezer. Voorbeelden van spanning zijn bijvoorbeeld het oplopen van een gebroken been als onbekende gebeurtenis, of mensen die tegen hun verwachting in goed worden geholpen in een ziekenhuis. Maar spanning treedt ook op wanneer het handelen in het verhaal niet leidt tot de gewenste doelen (bijvoorbeeld genezing of geruststelling) van de hoofdpersonen.

De verhaallijnenanalyse in dit onderzoek heeft geleid tot negen ervaringstypen of situaties die elk een aantal gelijkwaardige verhalen representeren. Een uitgebreid verslag van de verhaallijnenanalyse is te vinden in de digitale bijlagen. Aanvullend hierop is door het Rathenau Instituut en de Universiteit Twente gezamenlijk een thematische analyse gemaakt van de betekenis van kwaliteit van zorg voor de verhalenindieners. Hiervoor zijn de eerste vijftig ingediende verhalen gebruikt. Gekeken is hoe thema's die uit de literatuur bekend zijn over kwaliteit en veiligheid van zorg in die verhalen worden benoemd. Verder is gezocht naar aanvullende thema's (Barbour 2001). Dat heeft geleid tot inzichten 
in zes thema's die voor patiënten onderdeel uitmaken van goede kwaliteit van zorg: bejegening, organisatie van de zorg, professionele deskundigheid, informatievoorziening, toegankelijkheid en autonomie. Deze thema's zijn met nadere analyse verder ingevuld. De bevindingen zijn geïntegreerd in de beschrijvingen van de vier overstijgende thema's. Zie digitale bijlagen voor het complete verslag.

De negen ervaringstypen hebben we in workshops voorgelegd aan afgestudeerde artsen, ervaren artsen, verpleegkundigen en representanten van patiëntenorganisaties. Daardoor kregen we meer zicht op hoe we ervaringsverhalen kunnen begrijpen vanuit de bredere context van het ziekenhuis (viWTA 2006). $\mathrm{Na}$ de kennismaking met de schrijvers in de volgende paragraaf, volgt een korte weergave van de belangrijkste punten uit deze discussies. Zie digitale bijlagen voor het gevolgde protocol.

\subsection{Kennismaking met de schrijvers - wie deden er aan het} onderzoek mee?

Gedurende de opening van de website (in de periode van juni 2012 tot juli 2013) zijn er in totaal 109 verhalen ingediend, afkomstig van 103 schrijvers. De groep mensen die heeft gereageerd op de oproep en een verhaal heeft ingediend, is zeer heterogeen qua geslacht, leeftijd, afkomst, opleidingsniveau en inkomen. Wel zijn - niet geheel onverwacht - vrouwen (77 procent) en hogeropgeleiden (53 procent) oververtegenwoordigd. Bovendien waren de verhalenschrijvers vooral autochtone Nederlanders (94 procent). Zie tabel A in digitale bijlagen. De antwoorden op de vragen over het ingediende verhaal laten zien dat het project heeft geleid tot een zeer rijk en divers aanbod aan verhalen. Er zijn zowel positieve (25 procent) als negatieve (26 procent) verhalen ingediend, al worden de meeste verhalen door de indieners getypeerd als ambivalent (43 procent met zowel positieve als negatieve ervaringen) en een klein deel als neutraal (6 procent). Vragen naar ervaringen levert dus zeker niet alleen 'klaagzangen' op, zoals vooraf werd gedacht.

In de meeste gevallen is de schrijver zelf de patiënt in het verhaal (76 procent). Soms is de schrijver een ouder (7 procent), de partner (7 procent) of een kind (4 procent) van degene die ziek is. In het overgrote merendeel van de verhalen speelt een specialist (of zaalarts) een belangrijke rol (87 procent van de verhalen), maar ook over verpleegkundigen (51 procent van de verhalen) en over de huisarts (42 procent van de verhalen) wordt vaak geschreven. In een aantal gevallen komen er in het verhaal ook nog andere personen voor dan de patiënt/schrijver en de zorgverlener(s). Het betreft dan meestal familieleden, vrienden/kennissen of medepatiënten.

Het aantal verhalen laat zien dat het initiatief zeker aansluiting vindt bij een grote groep mensen. De aard van de verhalen toont aan dat de website Patiënten Weten Beter niet slechts wordt gezien als een 'klaagbank': patiënten zijn wel degelijk bereid (ook) hun positieve ervaringen te delen. Opmerkelijk is overigens het grote aantal ambivalente verhalen, waarin zowel positieve als negatieve ervaringen worden beschreven. Dit geeft aan dat ziekenhuiservaringen wellicht moeilijk zijn uit te drukken in een eendimensionale maat als een rapportcijfer.

\section{Breed scala aan zorgervaringen}

De ingediende verhalen hebben betrekking op een zeer breed scala aan zorgervaringen. Er zijn verhalen over zowel perifere (73 procent) als academische ziekenhuizen (24 procent). De beschreven ervaringen hebben plaatsgevonden door het hele land, al zijn de provincies Noord-Holland (22 procent), ZuidHolland (25 procent) en Brabant (18 procent) licht oververtegenwoordigd. De beschreven ziekenhuiservaringen betreffen veelal een ziekenhuisopname (64 procent) en betreffen meer dan dertig verschillende specialismen en meer dan vijftig verschillende aandoeningen. 


\section{Ervaringen van patiënten en reacties hierop van zorgverleners}

4.1 Negen archetypische ervaringen met ziekenhuiszorg Uit de verhalen blijkt dat een verblijf in het ziekenhuis geen neutrale ervaring is voor mensen. Het roept juist sterke gevoelens op. Het gaat immers om ziekte, gezondheid en onzekerheid. In interactie met naasten en zorgverleners leidt dat tot een verscheidenheid aan ervaringen. Uit de verhalen op de website komen met behulp van de narratieve analyse negen typen ervaringen naar voren. Elke type representeert meerdere verhalen van patiënten:

1. de patiënt ervaart onzekerheid en wanhoop over het leven met de aandoening;

2. de persoon voelt zich gesteund door een beetje extra hulp;

3. de patiënt is de bewaker van goede zorg;

4. de patiënt of partner is coprofessional;

5. de patiënt ziet fouten in het systeem en raakt verontrust;

6. de patiënt voelt zich niet geïnformeerd en onmondig bij een onprettige behandeling;

7. de patiënt of partner is onmachtig in een (falend) zorgproces;

8. de patiënt voelt zich in de steek gelaten door gebrek aan goede zorg;

9. de patiënt heeft een goede ervaring, ondanks lage verwachtingen.

De verschillende verhaaltypen laten zien dat in elke ervaring samenhang is tussen het soort patiënt met hoop, angst en verwachtingen, de betekenis die patiënten geven aan kwaliteit van zorg en autonomie, en de rol die zij zien weggelegd voor zichzelf, hun naasten en zorgverleners. Hoe dat per type verschilt komt aan bod bij de bespreking van de vier thema's in het volgende hoofdstuk. De ervaringstypen zijn eerst voorgelegd aan zorgverleners.

\subsection{Workshops - ervaringen van zorgverleners met} patiëntenervaringen

In vier workshops kregen net afgestudeerde artsen (artsen in opleiding) (23-052013), verpleegkundigen (06-06-2013), vertegenwoordigers van patiëntenorganisaties (11-06-2013) en al langer werkende artsen (25-06-2013) steeds drie ervaringenstypen - door middel van drie voorgelezen verhalen - voorgelegd. Het draaiboek en verslagen van de workshops zijn te vinden in de digitale bijlagen. De net afgestudeerde artsen waren allemaal opgeleid in hetzelfde academische ziekenhuis. Dat kan leiden tot bias vanwege een gedeelde werkcultuur. De oudere artsen en de verpleegkundigen waren via een bureau geselecteerd uit verschillende ziekenhuizen verspreid door Nederland. De deelnemers van de patiëntenorganisaties en de net afgestudeerde artsen werden persoonlijk benaderd door het Rathenau Instituut.
In de workshops werden de deelnemers op basis van de drie verhalen drie vragen voorgelegd:

1. Wat doet men met patiëntenervaringen?

2. Zijn er aan de hand van de drie patiëntenverhalen concrete mogelijkheden te benoemen om de ziekenhuiszorg te verbeteren?

3. Zijn er mogelijkheden tot het verbeteren van de zorg door het gebruiken van patiëntenervaringen in het algemeen?

\subsubsection{Wat doet men met patiëntenervaringen?}

In hoeverre zijn zorgverleners op de hoogte van ervaringen van patiënten? De ervaren artsen en verpleegkundigen kennen patiëntenervaringen via de PROMS- en de CQ-indexen. De resultaten van deze onderzoeken worden op de afdelingen besproken en leiden soms tot verbeteringen in de zorg. De onervaren artsen kennen de CQ-indexen niet. Wel hebben enkelen ervaring met een leidinggevende die patiëntenervaringen gebruikt om gedragsadvies aan de onervaren artsen te geven. De vertegenwoordigers van patiënten kennen ervaringen via hun leden, bijvoorbeeld via eigen enquêtes, lotgenotendagen of lotgenotencafés, spontane bellers of schrijvers, en via interviews, focusgroepen, groepsgesprekken, spiegelbijeenkomsten en werkgroepen die bijdragen aan het ontwikkelen van indicatoren voor ziekenhuizen.

Alle artsen en verpleegkundigen krijgen regelmatig spontaan verhalen van individuele patiënten, zowel positieve als negatieve. Sommige ervaren artsen vragen zelf om feedback. Een ervaren arts hoort ervaringen ook via de patiëntenvereniging. Ze horen bovendien de verwachtingen van patiënten voorafgaand aan de behandeling of ervaringen van patiënten met deze of eerdere behandelingen bij de nacontrole. Een vertegenwoordiger van een patiëntenvereniging meent dat artsen de ervaringen van hun patiënten vaak helemaal niet te horen krijgen. "Dat is jammer, want dan kan de arts er ook niks van leren." Maar, stelt ze, de patiëntenvereniging koppelt zelf verhalen ook niet altijd systematisch terug.

Verpleegkundigen hebben verschillende strategieën om feedback van patiënten te krijgen. Soms wachten ze tot de patiënt zelf ergens mee komt. Maar vaak vragen de workshopdeelnemers actief om de mening van hun patiënten. Dat gebeurt vaak bij het opname- en het ontslaggesprek. Soms wordt actief geïnformeerd naar de ervaringen met andere behandelaars uit het team. Ervaringen komen soms ook van de familie van de patiënt. Sommige verpleegkundigen geven standaard een enquête mee: "Als mensen klachten hebben, vullen ze die vaak daadwerkelijk in." Een andere manier om patiëntenervaringen te horen, is ernaar vragen bij baliemedewerkers: "Die hebben de hele dag patiënten aan de telefoon." 
De artsen in opleiding en ook de verpleegkundigen stellen dat patiënten steeds mondiger worden en hun mening vaak spontaan delen. Zelf vragen de jonge artsen er niet expliciet naar, behalve als het om een bekende gaat. Bovendien is de ervaring van zowel de artsen in opleiding als de verpleegkundigen dat zij veel ervaringen horen die specialisten niet horen. Patiënten zijn eerlijker tegen hen dan tegen de eigen arts. Als redenen worden genoemd dat de arts de patiënt maar een keer per dag ziet en de professionele arts-patiëntrelatie patiënten minder uitnodigt om ervaringen te delen. De artsen in opleiding hebben de ervaring dat oudere allochtone patiënten regelmatig het antwoord geven dat ze denken dat de arts wil horen. Een deelnemer zegt verhalen van patiënten belangrijk te vinden als graadmeter van de algemene kwaliteit van de zorg, als reflectie op de zorg. Een andere deelnemer vindt dat artsen wel meer zouden mogen uitstralen dat de ervaring van de patiënt hen interesseert.

Opvallend is dat in alle workshops veel deelnemers meerdere malen opmerken dat ze bijna niet kunnen geloven dat een bepaald voorval ook echt zo is gebeurd: "ledereen maakt fouten, maar als je dit leest denk je: dat kan haast niet." En: "Dat het zo vaak misgaat, is wel heel bizar en ernstig." Deze reactie kan wijzen op meerdere betekenissen van de beschreven ervaringen. Óf de door ons verzamelde ervaringen wijken echt af van de gemiddelde zorg in het ziekenhuis, en zijn dus echte uitzonderingen. Óf het duidt erop dat er nog ruimte is voor verbetering van de ziekenhuiszorg; waarbij patiëntenervaringen voor inzichten zorgen die niet goed op andere wijze te verkrijgen zijn.

\section{In hoeverre beïnvloeden ervaringen het handelen van zorgverleners?}

De artsen in opleiding vertellen dat ze eigenlijk alleen iets kunnen doen met de patiëntenervaringen die over hun eigen handelen als individuele arts gaan. Bij verhalen over directe collega's is handelen veel lastiger, laat staan bij verhalen over onbekende artsen of andere ziekenhuizen. Reden die daarvoor worden gegeven zijn dat de verhalen van de andere betrokkenen nodig zijn om een goed beeld te krijgen, tijdgebrek, de ervaring niet ernstig genoeg vinden om aan te kaarten bij collega's en het (veronderstelde) gebrek aan invloed. De jonge artsen zitten immers in een opleidingspositie. Soms twijfelen deze artsen ook aan de waarde van het verhaal: is het zinvol of gezeur? En soms is de manier waarop de patiënt het verhaal vertelt reden om van handelen af te zien: "Als iemand klakkeloos zijn mening ventileert, ga je er niet veel mee doen."

De ervaren artsen lijken actiever om te gaan met ervaringsverhalen. Ze geven aan goed te luisteren naar de patiënt en te informeren, bijvoorbeeld over de duur van de behandeling. Bovendien bespreken ze ervaringen met collega's en passen soms het eigen gedrag aan. Wel is het zo dat elke deelnemer zijn eigen aanpak lijkt te hebben, die bovendien per afdeling en per ziekenhuis verschilt.

Verpleegkundigen vinden patiëntenervaringen erg belangrijk. Sommigen trekken het zich bijna persoonlijk aan: "Ik wil het altijd meteen zo goed mogelijk doen. En het oplossen als het niet goed was, zelf of in overleg met het team." De ervaringen zijn een manier om de zorgverlening te verbeteren. Er wordt we onderscheid gemaakt tussen objectief terechte klachten en klachten die alleen terecht zijn in de beleving van de patiënt. De aanleiding voor zo'n klacht van de tweede soort zit soms in de persoonlijke situatie van de patiënt, zoals onmacht of angst. Dat kan aanleiding zijn om met de patiënt te praten om de onvrede weg te nemen.

'Echte' klachten worden altijd serieus genomen en leiden tot actie. "Als er iets kleins verbeterd moet worden, doen we dat zelf. Als het op hoger niveau ligt, signaleren we het, zodat ze het op andere afdelingen ook kunnen aanpakken, indien nodig." Dat kan leiden tot betere informatievoorziening, het prettiger laten verlopen van de vervolgbehandeling of tot het bijstellen van de verwachtingen van de patiënt.

Bij slechte ervaringen stimuleren verpleegkundigen dat de patiënt een formele klacht indient, zodat "dingen opgepakt en inzichtelijk gemaakt kunnen worden". Of de patiënt daarna echt een klacht indient, en wat ermee gebeurt, weet men vaak niet. Een aantal verpleegkundigen denkt wel dat er minder formele klachten worden ingediend dan zou kunnen, omdat het woord 'klacht' patiënten afschrikt. Dat is jammer, omdat klachten een goede aanleiding zijn om zaken te verbeteren. Ook de patiëntenverenigingen herkennen soms schroom bij patiënten om zaken aan te kaarten. Bijvoorbeeld dat men al langer klaagt zonder effect, en liever een andere behandeling of arts zou willen, of een second opinion.

De meeste verpleegkundigen gaan anders om met ervaringen dan artsen. Eén verpleegkundige zegt dat artsen wel openstaan voor ervaringen van patiënten, maar dat verpleegkundigen dingen signaleren die artsen missen: "Wij moeten ze toch vaak aan hun jasje trekken." Dat komt door hun verschillende rollen en taken. Artsen hebben kortdurender contact met patiënten, en patiënten zijn soms minder eerlijk of volledig tegen de dokter. En verpleegkundigen zijn beter benaderbaar. Sommigen helpen wel eens de communicatie tussen de patiënt en de arts te bevorderen, door de patiënten te stimuleren vragen te stellen of door de arts te vragen nog een keer tijd te maken voor de vragen van de patiënt en eventueel met de patiënt mee te gaan.

De patiëntenverenigingen gebruiken de verhalen van patiënten vooral als input voor allerlei (zorgverbeter)trajecten, onderzoeksagendering, beleidsagenda en andere gelegenheden waarvoor hun expertise en meedenken wordt gevraagd. De patiëntenverhalen gelden daarnaast als input bij het houden van presentaties, lezingen en workshops, of worden gebruikt als content op de website en het ledenblad. De verhalen worden ook gebruikt bij het registreren van problemen die patiënten hebben in de zorg, soms ook in opdracht van zorgverleners, en om mensen naar de juiste specialisten en voor second opinions te verwijzen. 
4.2.2 Zijn er aan de hand van de drie patiëntenverhalen concrete

\section{mogelijkheden te benoemen om de ziekenhuiszorg te verbeteren?}

De artsen in opleiding herkennen de beschreven situaties uit hun dagelijkse ziekenhuispraktijk, maar oordelen er verschillend over. In één verhaal wordt een patiënt steeds niet gehoord over een chronische aandoening. Daarop is de reactie van sommige artsen dat ze er niet zomaar van uit kunnen gaan dat de informatie die een patiënt doorgeeft, klopt. "Patiënten kunnen wel alles zeggen, dus je gaat alles overdoen, ook al kost dat tijd." De ervaren artsen reageren hie begripvol op. "Een beginnend arts-assistent die zo'n patiënt ziet, kan niet weten dat zo'n patiënt zelf al alles over zijn ziekte weet." Bij de ervaren artsen is er veel herkenning in de verhalen en ook begrip voor de vervelende situatie van patiënten. Vooral wordt opgemerkt dat het vervelend is als patiënten niet serieus genomen worden als mens.

De artsen in opleiding vragen zich af of dit soort verhalen een meerwaarde heeft naast de MIP (Meldingen Incidenten Patiëntenzorg, red.). Echter, niet elke situatie die een patiënt als onveilig ervaart, leidt tot een MIP. En er zijn misschien ook situaties waar de patiënt iets heeft gezien dat het personeel niet heeft opgemerkt. De ervaren artsen vinden het belangrijk dat de patiënt het proces mede bewaakt. Een merkt op: "Ik vind het idioot dat wij in dit land vinden dat een EPD (Elektronisch Patiënten Dossier, red.) buiten het bereik van de patiënt gehouden moet worden. Dat is absoluut niet nodig en bovendien heel gevaarlijk."

De ervaren artsen zien het bovendien vaak fout gaan in de communicatie tussen afdelingen, waardoor de patiënt tussen wal en schip terechtkomt. Door de schaalvergroting van ziekenhuizen kennen medewerkers elkaar vaak minder goed. Dat kan ten koste gaan van overleg en logistiek: "Een radioloog die ik persoonlijk ken zal niet zomaar zeggen: 'Ja hallo, die echo is niet spoed, ik ga hem niet doen.'"

Ook de verpleegkundigen zien herkenbare elementen in de verhalen. Vooral als het gaat over afspraken voor medicatie die telkens ter discussie worden gesteld. Maar het komt ook voor dat patiënten of hun familie de gang van zaken in het ziekenhuis anders interpreteren dan verpleegkundigen. Bijvoorbeeld rondom het druppelen van ogen: "Mensen zeggen dan bijvoorbeeld: 'Ik doe dat thuis altijd om acht uur' en als wij het dan om halfnegen doen hebben ze al tegen hun dochter gezegd: 'Die zuster heeft er geen zin in, want die komt pas heel laat."

De vertegenwoordigers van patiëntenverenigingen merken op dat patiënten te vaak niet als compleet mens worden benaderd, maar als onderdeel. Ze herkennen ook dat er vaak inefficiënt wordt gewerkt. Als oorzaak daarvan wordt genoemd het werken met papieren statussen in plaats van met een digitaal ziekenhuisdossier. De dossiervorming is daardoor soms niet op orde. Verder wordt het toedienen van medicatie op het medisch gezien verkeerde moment of op de verkeerde wijze genoemd als iets wat ook bij hen regelmatig voorkomt. Daarentegen hebben alle deelnemers ook veel begrip voor de mogelijke invloed van de tijdsdruk waaraan verpleegkundigen en artsen blootgesteld worden.

\subsubsection{Zijn er mogelijkheden tot het verbeteren van de zorg door het}

\section{gebruiken van patiëntenervaringen in het algemeen?}

De artsen in opleiding zien aan de ene kant wel iets van de waarde om vanuit het perspectief van de patiënt te denken. Veel verhalen bieden handvatten tot potentiële verbetering van de zorg, met name op het gebied van communicatie en procedures, zoals betere communicatie door ziekenhuismedewerkers, het tijdig schrijven van recepten en de gang van zaken rond het ontslag. Het is belangrijk om duidelijker te zijn naar de patiënt over het zoekproces naar de juiste diagnose, en te zorgen dat de patiënt zich gehoord voelt. Zij merken op dat één verhaal van één individuele patiënt al veel inzicht kan geven. Als arts

kun je door een persoonlijk verhaal meer geraakt te worden dan door een cijfermatige enquêteuitslag. Bovendien komt uit deze verhalen naar voren wat patiënten zelf belangrijk vinden. "Wij kunnen ons daar misschien niet in inleven. Dus we vragen dat niet eens.

Aan de andere kant vinden de artsen in opleiding dat er grenzen aan patiëntenervaringen zitten. Om tot een oordeel te komen over medisch handelen - en to een eventuele verbetering daarvan - zijn patiëntenverhalen ongeschikt:

"Daarvoor heb je het medische verhaal nodig en dat kan een patiënt gewoon niet geven." Een specifiek persoonlijk verhaal kan hoogstens dienen ter illustratie van een trend, als achtergrondinformatie: "Als je botte dokters wilt overtuigen dat het anders moet, moet je met cijfers aankomen." Je kunt niet met allerlei persoonlijke factoren rekening houden. Bovendien kost het tijd en "de werkdruk is al hoog", dat levert weerstand op. Tegemoetkomen aan de wensen van patiënten wordt daarentegen wel gezien als een slimme strategie, in het kader van de onderlinge concurrentie tussen ziekenhuizen.

De ervaren artsen denken daar anders over: "De klant is koning. Binnen redelijke grenzen." En daarom is ook de subjectiviteit van de patiëntenervaring geen probleem: "Het gaat om patiëntentevredenheid, dat is per definitie subjectief." De patiënt zou centraal moeten staan en niet de organisatie, vinden ze: "De patiënt komt hier om behandeld te worden en wij passen alles aan om hem of haar zo goed mogelijk te behandelen." Dat doen ze toch het meest, en wel door echt te luisteren naar de patiënt. Eén ervaren arts vindt het vreemd dat het in andere bedrijfstakken wel heel normaal is om het hele proces en de ervaringen van klanten te monitoren. "Maar in de zorg vinden we het 'te veel werk' of 'subjectief'." 
De patiëntenverenigingen stellen dat verhalen wel echt kunnen helpen om ziekenhuizen te veranderen van inefficiënte zorg naar klantgerichte dienstverlening. Daarin staat de patiënt centraal als een klant die dienstverlening inkoopt, daarvoor betaalt en dus recht heeft op kwaliteit. De vertegenwoordigers van patiëntenverenigingen zien in de ervaringen vooral lessen voor communicatie en 'beter naar elkaar luisteren'. Men merkt op dat er meer efficiëntie nodig is in de zorg en dat de ervaring van de patiënt daarbij nuttig is. Het perspectief van de patiënt zou medebepalend moeten zijn voor de beroepsmatige houding en het handelen van de zorgverlener, vindt men. Positieve verhalen zijn aan te bieden als voorbeeld voor andere ziekenhuizen, een beschrijving van goede zorg ter inspiratie voor anderen. Een verhaal overtuigt ook, omdat het concreet is. Maar ze zijn ook kritisch: waar 'landt' het verhaal? Het maakt uit of dat bij een Raad van Bestuur is of op de werkvloer. En bovendien: door negatieve verhalen kunnen zorgverleners zich aangevallen voelen.

Verpleegkundigen stellen dat patiëntenervaringen heel nuttig kunnen zijn. Maar de meningen verschillen of patiëntenenquêtes voldoen of dat verhalen ook zinvol zijn. Enquêtes leveren cijfers op. En alleen daarmee kun je volgens hen geld loskrijgen van het management voor verbeteringen. Maar, zeggen ze ook: "Kleine dingen kun je binnen een team veranderen naar aanleiding van een persoonlijk verhaal. Ook geeft een verhaal meer context. Als iemand een 3 geeft voor een opname denk je: jee, wat slecht. Maar zodra de context duidelijker is, wordt ook duidelijker wat de betekenis van dat cijfer is."

\section{Inleiding tot de thema's: vormgeven aan kwaliteit van zorg, autonomie en mondigheid}

Uit de verschillende onderdelen van het onderzoek verschijnen een aantal thema's die een rol spelen bij de manier waarop mensen vorm geven aan autonomie en mondigheid in het ziekenhuis of juist belemmeringen ervaren. De thema's zijn:

1. Onzekerheid of angst in een onbekende situatie;

2. Moeizame waardering van mondige en actieve patiënten

3. Onmondig in het ziekenhuissysteem;

4. Onbekende verwachtingen - bij patiënten én zorgverleners.

De thema's worden in de volgende hoofdstukken besproken en ingeleid door de bijbehorende ervaringsverhalen. Per thema wordt uitgelegd welke betekenis van autonomie en kwaliteit van zorg patiënten even aan de zorg die zij in het ziekenhuis ontvingen. Vervolgens wordt deze betekenis afgezet tegen de reactie van de zorgverleners die wij voor dit project hebben gesproken en geïnterviewd. Elk thema eindigt met een conclusie over de betekenis van goede zorg vanuit het perspectief van patiënten. 


\section{Onzekerheid of angst in een onbekende situatie}

\subsection{Patiëntenervaringen ${ }^{2}$}

In de twee onderstaande verhalen is een persoon aan het woord die plotseling (ernstig) ziek is. In het eerste verhaal heeft iemand te horen gekregen dat zij een ernstige ziekte heeft, die bovendien chronische pijn en verminking kan veroorzaken. De aandoening beheerst al een tijdlang het leven van deze persoon, vanwege de pijn, vermoeidheid en onzekerheid waarmee de aandoening gepaard gaat. Deze persoon voelt zich wanhopig en vreselijk onzeker over hoe het verder moet met haar leven. Ze zou willen dat ze hierbij wordt ondersteund of geholpen, maar in plaats daarvan voelt ze zich er alleen voor staan. Vanuit het ziekenhuis ervaart deze persoon weinig steun.

Het tweede verhaal gaat ook over iemand die met een ernstige aandoening wordt geconfronteerd, plotseling, maar die ondanks de angst en wanhoop die ze heeft doorgemaakt, de episode in het ziekenhuis als positief ervaart.

Dat komt, in haar ogen, door de inzet en aandacht van de verpleegkundigen en de artsen.

Verhaal 1:

De patiënt ervaart onzekerheid en wanhoop over het leven

met een aandoening

\section{Angst voor levenslange ziekte}

Drie jaar geleden kreeg ik mijn eerste cyste, in mijn lies. Het leek een soort puistje. De cyste verdween na een paar weken, maar kwam terug. Groter en pijnlijker. Toen dit zo een aantal maanden doorging, raadden mijn ouders mij aan om naar de huisarts te gaan. Dat deed ik, na een jaar aarzelen. De huisarts zei me dat ik de cyste onder lokale verdoving kon laten wegnemen. De verdoving was kort, maar zeer pijnlijk. Van de ingreep zelf voelde ik nauwelijks iets. De wond werd gehecht met draadjes die na tien dagen verwijderd werden door de huisarts. Ik kon anderhalve week niet werken. Een paar maanden later verschenen er opnieuw twee cystes. Grote dit keer, op mijn zitvlak. Ik raakte in paniek: niet dat terug, hè?! En zit met grote littekens.

2 Voor alle ervaringsverhalen geldt dat ze zijn ingekort, en dat de titels zijn aangepast. Taal- en spelfouten zijn verwijderd, en de namen zijn enigszins geanonimiseerd. De originele verhalen zijn te vinden via de digitale bijlagen.
Het viel mij op dat de cystes vaak rondom mijn menstruatie opkwamen. Dat vertelde ik de huisarts. Die verwees mij door naar een gynaecoloog, omdat ik misschien niet de juiste anticonceptiepil nam. Op aangeven van de gynaecoloog veranderde ik een aantal keer van pil, maar dat hielp niet. De cysten kwamen steeds terug. Ik kreeg antibiotica, eerst Staphycid en daarna Dalacin, en moest mijn liezen wassen met een soort wasgel. Maar toen de cystes weer terugkwamen, verloor ik de moed. Uiteindelijk zette ik de stap naar een dermatoloog, die me vertelde dat ik een moeilijk te behandelen huidziekte heb: hydradenitis suppurativa. Ik heb verschillende soorten antibiotica gebruikt, zoals Tetracycline, Refadine en Dalacin, maar kreeg weer cystes in mijn lies.

De dermatoloog vertelde me dat als de Dalacin niet zou werken, de enige andere oplossing een huidtransplantatie zou zijn. Maar dat zie ik eerlijk gezegd niet zitten! Ik ben mijn baan kwijt, omdat ik door de vele behandelingen vaak niet kon werken. Ik ben al drie jaar aan een stuk oververmoeid, voel me down. Ik heb altijd het bange gevoel dat de pijn terugkomt. Hoe gaat dit aflopen? Heb ik deze ziekte levenslang?

Natasja, 23 jaar

\section{Verhaal 2:}

De patiënt voelt zich gesteund door een beetje extra zorg

\section{Dankbaar voor liefdevolle zorg}

Mijn klachten begonnen met wat een flinke keelontsteking leek. Toen de antibiotica niet aansloeg, stuurde de huisarts mij door naar het lokale ziekenhuis. Daar werd pericarditis vastgesteld, een ontsteking van het hartzakje. Helaas bleek ik ook een bacteriële ontsteking te hebben Die werd mij bijna fataal. De cardioloog zag de ernst van de situatie in en liet mij per ambulance vervoeren naar het dichtstbijzijnde academische ziekenhuis. Daar onderging ik een spoedoperatie die mijn leven redde. Ik heb alles zeer bewust meegemaakt, tot het moment dat ik onder narcose ging en mijzelf overgaf aan de kundige handen van de artsen.

Het was een angstige ervaring. Maar ik ben de artsen zó dankbaar dat zij mijn leven hebben gered! Ik heb tien dagen op de intensive- en mediumcare-afdeling gelegen. Dat was een verwarrende tijd. Maar ik werd door het verplegend personeel liefdevol en aandachtig behandeld. Niets was hen teveel. Ik heb gezien hoe hard verpleegkundigen en artsen werken. Het ging gewoon dag en nacht door. De persoonlijke aandacht en integere houding waren een eyeopener. Ik kon alleen maar dankbaar zijn. 
Natuurlijk had ik ook minder fijne ervaringen tijdens dat verblijf. Zo merkte ik dat ik zelf goed moest opletten welke medicatie ik kreeg. Daar werden namelijk nog wel eens foutjes mee gemaakt. Dat was voor mij op zich niet zo erg, want ik was helder van geest. Ik denk ook dat ik een redelijk makkelijke patiënt was, niet te veeleisend. Toch gaven sommige stagiaires me wel eens het gevoel dat ik een lastpak was. Misschien hadden ze nog niet genoeg professionaliteit vergaard.

Ik denk dat ik door snel en kundig handelen en een goede diagnose een tweede kans heb gekregen in het leven. Ik heb tijdens mijn hele verblijf in het ziekenhuis gezien met hoeveel toewijding daar wordt gewerkt. Daardoor is mijn respect voor de medische wereld enorm gegroeid.

Wat mij vooral zal bijblijven, is the human touch van het medisch personeel. Zeker in de slapeloze nachten was ik tijdens de meest kritieke uren vaak wanhopig. En tegen het eind van mijn verblijf begon ik mijn gezin enorm te missen. Het luisterend oor en de zachte handdruk van de verpleegkundigen hielden het voor mij dragelijk. Ik denk dat wij in Nederland gezegend zijn met onze zorg.

Een zeer dankbare patiënte, moeder van twee jonge kinderen

\subsection{Angst, onzekerheid en wanhoop}

Ervaringen in het ziekenhuis worden gekleurd door de impact die een diagnose of aandoening heeft op het leven van patiënten. Een eenvoudige botbreuk of een soepel verlopende bevalling heeft een andere impact dan de diagnose van een levensbedreigende aandoening. Hoewel lang niet iedereen in het ziekenhuis komt vanwege een ernstige, pijnlijke of chronische aandoening, wordt uit de verhalen duidelijk dat de confrontatie met ziekte voor veel mensen een ongewone situatie is. Het verblijf in het ziekenhuis komt daar nog eens bij.

De mensen die in de wachtkamer terecht zijn gekomen, zitten daar (vaak) niet vrijwillig, maar vanwege letsel, pijn of iets verdachts. Kortom, vanwege een afwijking van het normale en alledaagse. Daardoor zijn mensen niet in hun alledaagse doen. Dat veroorzaakt stress, angst, en soms wanhoop. Dat heeft een grote impact op de manier waarop patiënten zich opstellen.

Uit de verhalen blijkt dat mensen ineens worden geconfronteerd met vragen over hoe het verder moet, hoe ze zelf regie kunnen houden en wat hen te wachten staat. Uit verschillende onderzoeken blijkt dat mensen meer dan de helft vergeten van wat artsen in de spreekkamer vertellen (Makaryus \& Friedman 2005; De Haes et al. 2006). Dat gebeurt vooral in situaties waarin patiënten een slechte diagnose hebben gekregen. Mensen stappen dan angstig en onwetend de spreekkamer uit. Of komen angstig binnen voor een onbekende behandeling en worden verder niet gerustgesteld. Dit blijkt ook in veel verhalen het geval.

\section{Gericht op genezing}

We zien in het eerste verhaal dat alle zorg is gericht op behandeling en genezing van de medische klacht van de patiënt; de steeds terugkerende cystes. Het feit dat het een moeilijk te behandelen aandoening blijkt te zijn geworden, waarbij de patiënt al drie jaar verschillende behandelingen ondergaat zonder dat er sprake is van genezing, heeft duidelijk een niet-medische impact op haar leven. We lezen dat ze in toenemende mate angst, paniek en moedeloosheid ervaart, en dat de ziekte er uiteindelijk zelfs toe heeft geleid da ze is ontslagen van haar werk en al drie jaar oververmoeid thuiszit. Niet alleen wordt in de ogen van de patiënt het doel niet bereikt, namelijk dat de cystes voorgoed verdwijnen, de ingezette middelen verergeren de situatie in haar ogen juist: de patiënt krijgt grote littekens, raakt in paniek doordat de kwaal eerder verergert dan afneemt, de pijn blijft terugkomen, ze verliest haar baan en wordt steeds onzekerder over de afloop. Met de verergering van de situatie worden de ingezette middelen ook steeds groter: van veranderen van anticonceptiepil tot zware antibiotica en van een kleine operatie tot een zeer breed chirurgisch ingrijpen. Geen moment wordt getwijfeld aan de noodzaak om de cystes te verwijderen, door patiënt noch zorgverleners, tot het moment van een grote chirurgische ingreep waarvan de patiënt duidelijk weet: dit zie ik niet zitten. Maar de patiënt lijkt niet in staat deze angst en wanhoop over te brengen op de artsen, met als gevolg dat zij zich alleen en wanhopig voelt. Deze persoon is niet mondig tegenover de artsen.

\section{Aandacht voor wanhoop}

Het tweede verhaal gaat ook over iemand die plosteling met een ernstige aandoening wordt geconfronteerd, maar die ondanks de angst en wanhoop die ze heeft doorgemaakt, de episode in het ziekenhuis als positief ervaart. Dat komt, in haar ogen, door de inzet en aandacht van de verpleegkundigen en de artsen Er was oor en oog voor haar afhankelijkheid, haar angsten en voor het gemis van haar jonge kinderen. In de kleine uurtjes van de nacht is er steun aanwezig. We zien in dit verhaal dat de zorg gericht is op zowel het herstel van een ernstige aandoening als op de impact die deze plotselinge aandoening heeft op de vrouw.

De aandacht voor de wanhoop en angst maakt blijkbaar veel verschil voor hoe iemand de zorg in het ziekenhuis ervaart en hoe iemand kan omgaan met een plotselinge levensbedreigende situatie. De vrouw in het tweede verhaal geneest helemaal in tegenstelling tot de vrouw met de cystes. Maar dat was niet meteen bij aanvang duidelijk, het had ook mis kunnen gaan. Omdat er vanuit het ziekenhuis veel steun was voor haar angst en wanhoop kijkt ze toch positief terug op de gebeurtenis. 
5.3 Goede zorg is: aandacht voor wanhoop en angst

Uit de verhalen blijkt dat het juist daarom belangrijk is om op een of andere manier aandacht of ruimte te geven voor deze gevoelens. Opvallend genoeg werd in de workshops met de artsen en verpleegkundigen nauwelijks ingegaan op de wanhoop en angst die patiënten kunnen voelen en de invloed die dat kan hebben op de manier waarop patiënten zich opstellen in het zorgproces. Een oorzaak zou kunnen zijn dat omgang met ziekte en zieke mensen voor zorgprofessionals hun dagelijkse werk is. De twee verschillende uitgangsposities - de patiënt die uit zijn gewone doen is vanwege onvrijwillige confrontatie met ziekte en de zorgprofessionals voor wie de situatie in het ziekenhuis het dagelijks werk is - kan tot spanning leiden op het niveau van intermenselijk contact. Mensen kunnen onmondig worden, of juist zeer assertief. In het eerste geval kan dat ertoe leiden dat mensen over het hoofd worden gezien. In het laatste geval dat mensen als lastig worden gezien en zo worden behandeld, zoals blijkt uit een aantal andere verhalen.

Goede zorg richt zich niet alleen op de medische kant van het verhaal, maar houdt ook rekening met de angst en wanhoop die mensen voelen na een diagnose of behandeling. Op die manier kan de persoon met de ziekte of aandoening meer grip krijgen op de situatie en dat kan een positief effect hebben op de genezing of de acceptatie en omgang met de ziekte. Dat blijkt ook duidelijk uit het eerste verhaal van de mevrouw met de pericarditis. Zij lijkt nu alleen te zijn met haar vragen en haar angst over de toekomst. Dit verhaal kan echter ook gelezen worden als een oproep om meer duidelijkheid te verschaffen over de langetermijngevolgen van haar conditie in plaats van alleen maar adhocmaatregelen te nemen zonder het doel daarvan kritisch te evalueren.

Meer aandacht voor de angst en wanhoop van mensen houdt in dat er aandacht en hulp wordt geboden bij het omgaan met een ziekte op de langere termijn en de impact die het op het gehele leven heeft.

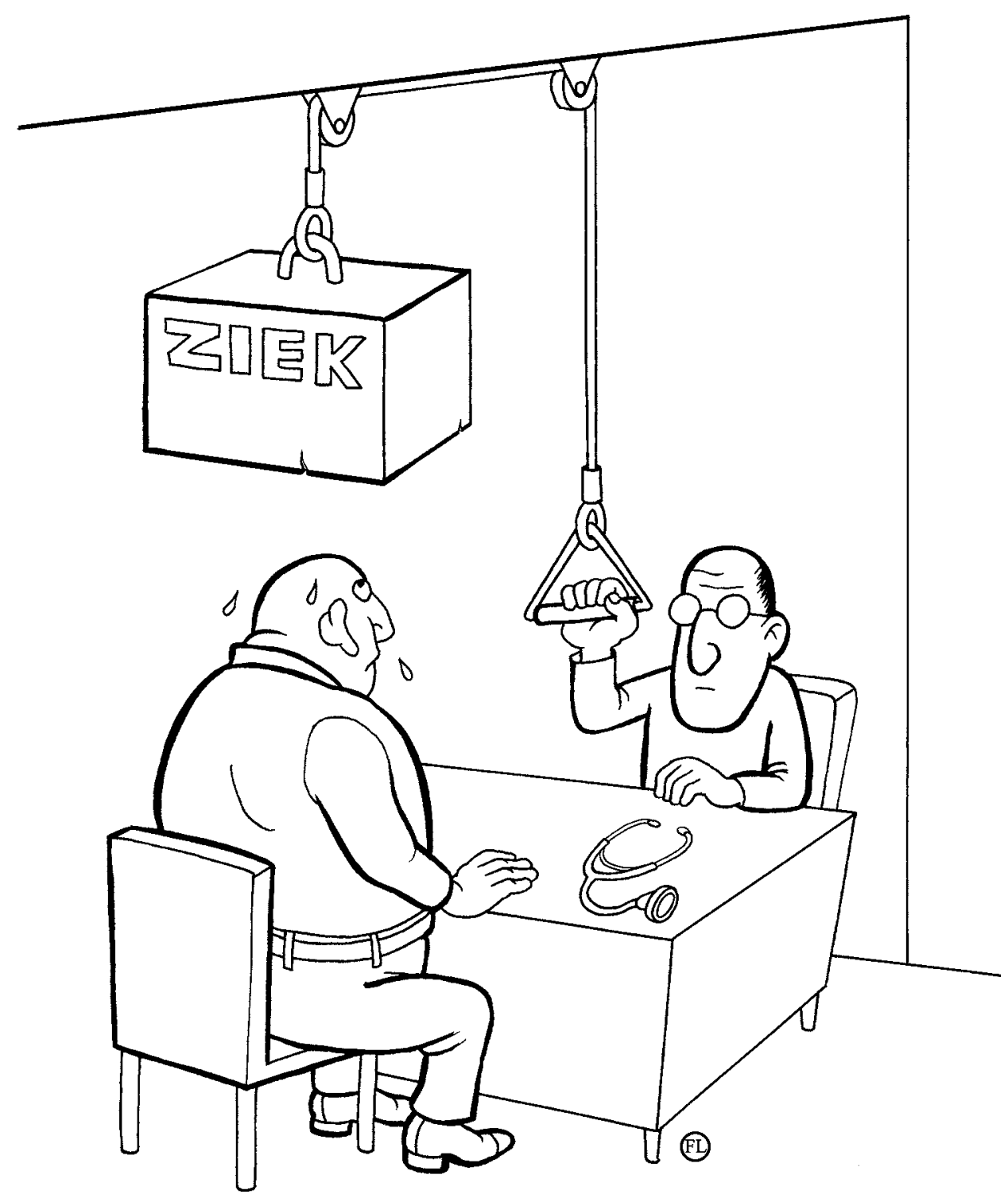




\section{Moeizame waardering van mondige en actieve patiënten}

\subsection{Patiëntenervaringen}

In de onderstaande drie verhalen draait het om patiënten en naasten die actief meedenken en -doen in het zorgproces, zowel vrijwillig als onvrijwillig, en die het om uiteenlopende redenen beter denken te weten dan de artsen en verpleegkundigen. Zij doen dit om een oogje in het zeil te houden (verhaal 3), dingen beter te laten lopen (verhaal 4) of om te voorkomen dat het misgaat (verhaal 5). Ze zien veel dingen die goed gaan, maar ook veel dingen die beter zouden kunnen.

\section{Verhaal 3:}

De patiënt is de bewaker van goede zorg

\section{Gelukkig ben ik zelf oplettend}

Ik had een hartinfarct gehad en lag op de afdeling cardiologie. Ik ben ook schildklierpatiënt en gebruikte toen Thyrax en Cytomel. Van de Cytomel nam ik twee keer per dag een kwart van een hele tablet van $25 \mathrm{mcg}$. Op een ochtend gaf de verpleegkundige een volledige tablet van $25 \mathrm{mcg}$. Ik zei dat dat te veel was. En zij vroeg me of ik het soms beter wist.

Maar het was maar goed dat ik zo oplettend was en niet naar haar geluisterd heb. De internist en de cardioloog wisten namelijk ook niet dat ik Cytomel gebruikte. Achteraf had ik het middel niet meer mogen gebruiken in deze situatie. Cytomel is een snelwerkend hormoon dat het hart beïnvloedt. Waarom werken artsen niet beter samen? De schildklier en het hart hebben zoveel met elkaar te maken! Gelukkig is er dit jaar aandacht aan besteed door de week van de schildklier van Schildklier Organisaties Nederland.

Mijn bloeddruk bleef het laatste jaar erg hoog. Ik vroeg mijn arts: 'Mijn FT 4 is vrij laag, moet ik niet meer schildklierhormoon hebben?' Hij vond het niet nodig en stuurde mij weer naar de cardioloog. Uit de toch kostbare onderzoeken die ik daar kreeg, kwam niets bijzonders naar voren. Ja, ik ben natuurlijk wel hartpatiënt met drie stens... Ik vroeg mijn huisarts de Thyrax wat te verhogen. Dat vond hij goed. En zie, mijn bloeddruk werd steeds beter.
Ik vind: dat zijn nu onnodige kosten in de gezondheidszorg. Ik vind ook dat artsen meer moeten weten over de schildklier. Daar wordt volgens mij in de opleiding te weinig aandacht aan besteed.

Julia

Verhaal 4:

De patiënt of partner als coprofessional

\section{Vijf uur wachten: hoezo spoedpoli?}

Op dinsdagmorgen had Floor, ons meisje van tien, veel pijn. Ze huilde en riep 'au'. Bijzonder voor iemand die niet kan praten en bijna nooit huilt. Het was vreselijk om te zien en niets te kunnen doen. En dit was al de tweede keer; een halfjaar geleden ging ik 's nachts met haar naar de Spoedeisende Hulp. Toen leverde het onderzoek niets afwijkends op, behalve kleine galsteentjes. Die waren volgens de kinderarts-assistent wel zeldzaam, maar vormden geen verklaring voor deze pijnaanvallen.

Ons kind is complex en er kon dus van alles aan de hand zijn. We redeneerden, probeerden en observeerden, maar woensdagavond was de grens bereikt. We grepen naar Tramadol, een pijnstiller uit de morfinehoek. Die bleek een halfjaar geleden effectief. Omdat het voor ons een nieuw en stevig middel was, belden we de dienstdoende kinderarts over een behandelplan voor de nacht. We spraken af dat we ons op donderdagochtend om tien uur zouden melden op de spoedpoli. Maar als de situatie 's nachts zou verergeren, mochten we direct naar de SEH komen voor een echo. Ook het medicatiebeleid voor de nacht stelden we samen helder op. 'Maar,' zei de dienstdoende arts, 'u moet vooral moeder blijven, wij zijn er voor het medische stuk.' Dat was natuurlijk goed bedoeld, maar zo werkte het niet in ons dagelijks leven. Juist als ouders van zo'n complex meisje zijn wij het 'klinisch oog'. Gelukkig deed de Tramadol zijn werk en sliepen we relatief goed.

Om tien uur donderdagmorgen werden we een spreekkamer binnengebracht, onze dochter nog in diepe slaap vanwege de Tramadol. Een halfuurtje later kwam de dienstdoende arts binnen. Hij vertelde dat hij het dossier kort had ingekeken, maar dat het te omvangrijk was om even snel te kunnen bevatten. Ik zei dat ik, zoals vorige keer afgesproken met de eigen kinderarts, graag een herhaling van de echo wilde om te kijken of die galstenen nu wel of niet een rol spelen. Deze wens zou worden meegenomen. Tot dusver prima. 
Ik wachtte ondertussen in de steriele kamer, waar niks te beleven viel. Enige tijd later kwam de dokter terug: bloed en urine waren direct afgenomen, maar de buikecho kon pas de volgende morgen om kwart over acht plaatsvinden. Floor was nu rustig en leek geen pijn meer te hebben, dus er was ook geen sprake meer van spoed, meende de dokter. Maar ik weet de ogenschijnlijke rust van mijn dochter aan de Tramadol. Ik had namelijk gezien hoe Floor reageerde toen de arts aan haar buik kwam en ik zag de frons op haar voorhoofd terwijl ze diep sliep. Maar nee, zei de arts, het kon echt niet anders. Hij moest weer weg, naar een ander kindje.

Ik wachtte op de bloedprikdienst en het afnemen van de urine. Het wachten duurde lang en het was nog wel een spoedpoli. Natuurlijk, we waren niet de enige patiënt, maar communicatie over wat, hoe en wanneer zou prettig zijn geweest. Al was het maar ongeveer. Het was inmiddels lunchtijd. Ik wilde geen lastige patiënt zijn, dus bleef ik rustig zitten. Ik voelde me ondertussen steeds meer een lijdend voorwerp dat ergens achter een deurtje zat. Daardoor kwam bij mij alles wellicht nog scherper aan. Ik dacht ondertussen: ik wil helemaal niet wachten tot morgen, die echo moet nu! We zitten toch niet voor niets op de spoedpoli? De pijn is nu en ik wil weten waar die vandaan komt. Ik wilde een oorzaak en misschien een oplossing. Zo was het toch ook afgesproken de vorige keer? Bovendien: onze dochter is onderdeel van een gezin met werkende ouders en twee andere schoolgaande kinderen.

Ik legde uit aan de arts (die inmiddels was verschenen) dat ik geen problemen wilde maken, maar dat ik wel graag zag dat mijn dochter nu die echo kreeg. Ik vertelde dat Floor zusjes heeft en een vader, dat ik vrijdag moest werken en dat gezien de situatie kwart over acht's ochtends niet handig was. De reactie was kortweg: "O." Ik wees er nog maar eens op dat mijn dochter pijn had. De reactie was: "Maar u mag nog gewoon Tramadol geven." En: "We weten nu niet hoe veel pijn uw dochter heeft." Maar ik wílde een meisje van tien geen Tramadol geven als symptoombestrijding. En ik wist wél dat Floor pijn had. De dokter probeerde nog eens om de röntgenafdeling te bellen. Ik wachtte weer in het witte kamertje. Tot de doktersassistente enthousiast binnenkwam om te vertellen dat we nu toch naar de röntgenafdeling mochten. Daar werd een echo gemaakt en toevallig liep ook de radioloog binnen, die meteen even meekeek. Officieus kreeg ik de uitslag: niets afwijkends, maar nog altijd die galsteentjes.

Ik ging terug naar de kinderpoli om met de doktersassistente te bespreken hoe ik de uitslag van de verschillende onderzoeken kon krijgen en wat het vervolg zou zijn. Net na drie uur liepen Floor en ik naa buiten. Vijf uren op de spoedpoli, vooral wachtend op een houten stoel.
Verhaal 5:

De patiënt ziet fouten in het systeem en raakt verontrust

\section{Wéér het verkeerde dossier}

Enkele jaren geleden ben ik geopereerd aan de aderen in mijn benen. Over deze operatie ben ik erg tevreden. Maar toen ik na de operatie terugkwam in het ziekenhuis voor controle, zag ik dat er iets niet klopte aan mijn medisch dossier. Het was beduidend dikker dan wat ik me herinnerde. Ik vertrouwde het niet en zei dat tegen de mevrouw achter de balie. Mijn vermoeden bleek juist: het dikke dossier was dat van mijn tweelingbroer, die eerder in hetzelfde ziekenhuis was geopereerd.

De baliemedewerkster schreef op het kaft van het dossier met een balpen en in blokletters 'MEERLING'. Dat viel niet erg op; een vette stift was beter geweest. Dat bleek later wel, toen ik bij een ziekenhuisbezoek zag dat men weer het verkeerde dossier in handen had. En ook mijn broer was hetzelfde overkomen met mijn dossier! Je moet er niet aan denken dat de arts je op basis van het verkeerde dossier opereert! Mijn angst hiervoor was zo groot dat ik later, terwijl ik op de operatietafel lag, vroeg of men even wilde controleren of men wel het juiste dossier had.

Eind februari 2012 werd ik weer geopereerd in hetzelfde ziekenhuis. Dit keer aan mijn aorta. Ik bleef hierna onder controle en zo'n zes maanden later had ik voor het eerst weer contact met de chirurg. Tijdens dit bezoek sprak hij mij aan over een liesbreuk waaraan ik onlangs geopereerd zou zijn. Bij mij ging er direct een groot licht branden. Want niet ik, maar mijn tweelingbroer had recent een liesbreukoperatie ondergaan.

Ongelofelijk, maar opnieuw was niet mijn medische dossier, maar dat van mijn broer erbij gehaald! Pas na mijn opmerking over de liesbreukoperatie van mijn broer kreeg de assistente dat in de gaten. En kennelijk waren er al dossierstukken verhuisd van mijn dossier naar dat van mijn tweelingbroer en andersom. Ik hoorde de chirurg namelijk zeggen tegen de assistente dat er dan iets uit het dossier gehaald moest worden.

Mijn zorg is natuurlijk dat dossierstukken in het verkeerde dossier terecht zijn gekomen. En de vraag is dan: is dat al eerder gebeurd en, zo ja, hoe vaak? Ik vind dit een zeer kwalijke zaak. Als op een dossier staat geschreven, 'MEERLING', moet er toch een lichtje gaan branden? Dan moet je toch extra controleren of je wel het juiste dossier in handen hebt. 
Ik heb overwogen een klacht in te dienen bij het ziekenhuis, maar ik vraag me af of dat zin heeft. Wel zou ik willen dat beide dossiers, dus zowel dat van mijn tweelingbroer als dat van mij, grondig worden doorgenomen om uit te kunnen sluiten dat dossierstukken in het verkeerde dossier zijn opgeborgen. Bij voorkeur in mijn bijzijn.

\subsection{Dunne lijn tussen mondig en lastig}

Veel ervaringsverhalen gaan over mensen die veel zien van het zorgproces of actief willen meedenken met hun ziekte en zorg en daarin niet gehoord worden door de zorgverleners. Of het gaat over mensen die zich genoodzaakt voelen goed op te letten om fouten te voorkomen. Veel patiënten met een chronische ziekte ontwikkelen zich tot zogenaamde 'protoprofessionals'. Ze hebben vaak veel kennis over het eigen lichaam en manieren waarop ziekte zich kan manifesteren (zie o.a. Prins 2008; Van de Bovenkamp 2010). Dat is vaak een voordeel, maar soms levert het problemen op met zorgprofessionals.

\section{Complexe aandoening?}

In het derde verhaal is een persoon aan het woord met een complexe aandoening. Als schildklierpatiënt komt zij na een hartinfarct in het ziekenhuis terecht, maar daar krijgt zij medicijnen die niet goed samengaan met haar andere medicijnen. Het ziekenhuis blijkt niet goed op de hoogte van de complexe combinatie van aandoeningen. De patiënt voelt zich hierdoor genoodzaakt zelf goed in de gaten te houden of zij wel de juiste behandelingen of medicijnen krijgt. Als zij niet zo oplettend zou zijn, is de kans groot dat het misgaat. De patiënt is dus de bewaker van haar eigen medische zorg. Dit zou, volgens deze patiënt, niet nodig hoeven zijn als er meer wordt samengewerkt tussen de verschillende specialisten, afdelingen of ziekenhuizen. Met andere woorden: als de zorg in het ziekenhuis niet zo gefragmenteerd is. Ook zouden de zorgverleners zelf zorgvuldiger naar de patiënt moeten luisteren; zowel de verpleegkundige als de huisarts luistert niet goed naar de aanwijzingen van de patiënt. Bovendien ervaart deze patiënt verspilling doordat zij, in haar ogen, dure en overbodige bezoekjes moet afleggen aan de specialist. Uiteindelijk wordt de patiënt ook nog gekleineerd door de verpleegkundige die opmerkt of zij het soms beter weet. Deze patiënt wéét het toevallig ook beter, maar wordt onmondig gemaakt.

\section{De patient of partner als coprofessional}

In het vierde verhaal gaat het om de partner van een patiënt met een chronische aandoening. De moeder in dit geval, zorgt dagelijks voor deze patiënt en voelt de noodzaak om bewaker van goede zorg te zijn voor de ander. In het ziekenhuis is het voor deze persoon logisch om de kennis en expertise met de artsen te delen en zelf suggesties te doen op basis van eerder gemaakte afspraken. Zij weet immers veel over de medische achtergrond en geschiedenis en kent de patiënt zeer goed. Dat gaat in eerste instantie goed, maar ten slotte steeds moeizamer. Het resultaat is dat deze persoon zich, tegen de verwachting in, buitenspel gezet voelt. Dat leidt in dit geval tot frustraties over het zorgproces, waarbij de partner zich miskend voelt.

Het probleem in deze situatie is dat de hoofdpersoon zowel een bezorgde moeder is die de beste zorg voor haar dochter wil, maar ook de spreekbuis en medische expert van haar dochter. In de thuissetting levert de combinatie van haar verschillende rollen geen spanningen op. Maar wanneer de hoofdpersoon in aanraking komt met de professionele setting van het ziekenhuis is het afwachten of deze persoon serieus genomen wordt in haar rol als expert.

In dit verhaal is een moeder van een patiënte aan het woord, maar dezelfde principes komen ook voor in de verhalen waarin patiënten spreken die zichzelf als expert zien van hun eigen ziekte. De schildklierpatiënt in het vorige verhaal is daar ook een voorbeeld van. Deze patiënten en partners willen graag betrokken worden als expert bij de zorg die zij krijgen. Maar zij krijgen daartoe in deze verhalen niet veel kans door de houding van de betrokken zorgverleners.

\section{Dossierwisseling}

Het probleem in het vijfde verhaal is het dossier. De medische handelingen lijken wel in orde te zijn - de patiënt zegt daar ook niets over - maar deze persoon verliest desondanks het vertrouwen in de zorg doordat de administratieve processen niet op orde zijn. De continue verwisseling van de dossiers baart hem ernstige zorgen. Hoewel deze persoon door het ziekenhuis wel gehoord wordt, verbetert de situatie in structurele zin niet. Het ziekenhuis neemt de patiënt eigenlijk niet serieus en zet in de ogen van de patiënt diens veiligheid op het spel. De patiënt voelt zich in een rol gedrukt van gedwongen bewaker van goede zorg, waarvoor hij zich niet voelt toegerust. Alleen al omdat hij in zijn eentje niet zoveel aan de dossierwisselingen kan veranderen. De patiënt is weliswaar mondig en alert, maar voelt zich daar niet geruster door. De vraag is ook of die angst door de zorgprofessionals wordt opgemerkt. Misschien vinden ze hem vooral lastig, omdat hij maar blijft doorgaan over de dossiers.

Patiënten die zich assertief opstellen, lopen het risico door zorgverleners als lastig en veeleisend te worden gezien. Dat blijkt uit de reacties van zorgverleners op patiënten die beschreven zijn in de verhalen. Ook uit de reacties van zorgverleners op het verhaal van het complexe meisje (verhaal 4) tijdens de workshops. De verpleegkundigen in de workshop kunnen eensgezind begrip opbrengen voor het 'moedergevoel', maar vinden ook dat de moeder "moet accepteren wat de arts beslist." Er wordt opgemerkt dat de grondhouding van de moeder ('ik heb recht op zorg') hen tegenstaat. Toch is het de vraag of deze moeder ten onrechte staat op het maken van een echo. Immers, deze echo was in eerdere contacten met een arts toegezegd. 
Blijkbaar wordt een patiënt die voor zichzelf opkomt en dus mondig is, snel gezien als lastig en veeleisend. Een aantal artsen in beide workshops merkt op dat ze in dit soort situaties bang zijn dat de mensen met de grootste mond het eerste een echo krijgen, in plaats van dat de arts op basis van medische indicatie de volgorde bepaalt. Het wordt in meerdere verhalen opgemerkt dat eigen inbreng of assertiviteit niet altijd gewaardeerd wordt in het ziekenhuis.

\subsection{Spanning tussen de meedenkende patiënt en het artsenperspectief}

\section{Begrip versus irritatie}

Gelukkig hebben artsen en verpleegkundigen vaak wel begrip voor meedenkende patiënten, blijkt uit de workshops met zowel de artsen als de verpleegkundigen. Zo merken verpleegkundigen tijdens de workshop op dat het ernstig is dat medicatieafspraken steeds weer ter discussie worden gesteld door zorgprofessionals. En ze zien ook voordelen aan meedenkende patiënten: "Ze houden je scherp en zorgen voor een extra controle." Een verpleegkundige merkt op dat ze juist blij is met een patiënt die haar bij de les houdt en zegt: "Ik zou nog een pilletje krijgen."

Maar er zijn ook veel gevallen waarin meedenkende patiënten niet gehoord worden, met een grapje gekleineerd worden of gewoon niet serieus worden genomen, De moeder uit verhaal vier wordt in eerste instantie in alle workshops met wat argwaan bekeken. De meeste deelnemers zien geen opvallende problemen in de behandeling van het zieke kind en vinden dat het best netjes gegaan is. Wel had er duidelijker naar de moeder gecommuniceerd kunnen worden wat ze kon verwachten van het ziekenhuis. Bovendien zijn veel deelnemers het erover eens dat het niet altijd makkelijk is om goed met ongeruste moeders om te gaan: "Je moet ze serieus nemen, maar ze roepen soms ook irritatie op," stelt een van de jonge artsen. Het is volgens hen dan ook ontzettend moeilijk om de balans te bewaren. "Je moet iemands kennis en ervaring met zo'n kind niet bagatelliseren of wegschuiven en toch ook als dokter het juiste beleid uitstippelen."

\section{Wie is verantwoordelijk?}

De meedenkende of geprofessionaliseerde patiënt staat blijkbaar soms op gespannen voet met het algemene artsenperspectief op de rol van de patiënt. Hoewel geen officieel standpunt, stelden Van Dijk en Willems van de KNMG in het gesprek met het Rathenau Instituut dat de patiënt niet verantwoordelijk zou hoeven zijn voor de kwaliteit van de zorg, omdat dat de taak is van de zorgverleners en het ziekenhuis. Immers: "Patiënten die niet zelf op hun medicatie kunnen letten, die moeten erop kunnen vertrouwen dat die medicatie goed is (interview KNMG, 19-03-2013)." Uiteraard kunnen we uit de ingediende verhalen niet afleiden hoe vaak het daadwerkelijk fout gaat of hoe vaak fouten voorkomen worden doordat patiënten opletten en hun zorg uiten. Maar uit vee verhalen blijkt dat patiënten zichzelf wel degelijk verantwoordelijk voelen - en moeten voelen - voor goede zorg.

Blijkbaar is het niet realistisch om de volle verantwoordelijkheid voor veilige en kwalitatief hoogwaardige zorg eenzijdig bij zorgprofessionals te leggen, gezien de veelheid aan verhalen die gemiste diagnoses en (bijna) fouten melden ${ }^{3}$.

De stem en ogen van de patiënt zijn, zoals blijkt uit de verhalen en uit de workshops met de artsen, vaak hard nodig om diagnoses te stellen of fouten te voorkomen. Maar de cultuur van het Nederlandse ziekenhuis lijkt het moeilijk te maken een dergelijke rol voor de patiënt te accommoderen. Deze spanning kan ertoe leiden dat het vertrouwen van de patiënt in de zorg van het ziekenhuis afneemt, omdat deze zich niet gehoord voelt of niet serieus genomen voelt, zoals we in meerdere verhalen hebben teruggezien. Veel schrijvers merken op dat zij voor zichzelf in deze situatie hebben gezorgd dat het goed ging door extra mondig te zijn, maar dat zij zich zorgen maken om minder mondige mensen die niet goed worden gehoord of voor de situatie waarin zij zelf ineens onmondig zijn en hun klachten of opmerkingen onopgemerkt blijven.

Uiteraard zien en horen artsen en verpleegkundigen ook veel lichamelijke klachten die vanzelf weer overgaan en geen ingreep behoeven. Dat maakt het lastiger om sommige geluiden serieus te nemen. Toch blijkt uit onderzoek dat naar schatting zo'n 10 tot 15 procent van de diagnoses die artsen stellen niet juist is (Willemsen et al. 2013). Gelukkig wordt uiteindelijk vaak tijdig de juiste diagnose gesteld, maar soms ook niet. Tunnelvisie is de vaak gebruikte term om aan te geven waarom artsen een bepaalde diagnose over het hoofd kunnen zien (ibidem). Juist daarom is het belangrijk om bij klachten die niet makkelijk in bestaande kaders passen, de patiënt zelf en diens naasten serieus te nemen. Mensen die de Nederlandse taal niet goed machtig zijn of minder kennis hebben van de cultuur in Nederlandse ziekenhuizen, vormen een extra moeilijke groep, zoals ook zal blijken uit ervaringsverhaal 7. Het bemoeilijkt de communicatie met zorgverleners, zoals zowel door de KNMG (interview KNMG 19-03-2013) als de artsen in opleiding wordt opgemerkt.

\section{Gesloten medische cultuur}

De bestaande hiërarchie in ziekenhuizen kan ertoe leiden dat negatieve ervaringen niet makkelijk worden erkend. De artsen in opleiding stelden eensgezind dat zij negatieve ervaringen van een patiënt zeker niet zouden terugkoppelen aan hun opleiders of andere specialisten, omdat ze vermoedden dat ze weinig invloed zouden hebben vanwege hun opleidingspositie. Maar ook de artsen die hun sporen verdiend hebben, kost het moeite feedback van patiënten terug te koppelen aan een collega-arts. Of, zoals een ervaren arts opmerkte: "Dat doe

Zie voor de verhalen de website www.patientenwetenbeter.nl of klik door via de digitale bijlagen. 
ik alleen als heel duidelijk is waar de fout lag en als het arts-assistenten of verpleegkundigen zijn. Naar een andere specialist zal ik dat minder snel doen."

\subsection{Goede zorg is: ruimte laten voor de eigen inbreng} van de patiënt

Goede zorg betekent goed luisteren naar de eigen inbreng van patiënten en deze serieus nemen. Het gaat bijvoorbeeld om suggesties van patiënten over de behandeling; patiënten die opmerken dat er iets in de behandeling dreigt fout te gaan, zoals bij de toediening van medicatie. Goede zorg betekent ook dat zorgprofessionals en instellingen bereid zijn ervaringen van patiënten serieus te nemen en hiervan te leren. En, dat ervaringen die betrekking hebben op de organisatie van zorg input vormen voor structurele verbetering van processen in de zorginstelling.

De patiënt serieus nemen kan spanning oproepen wanneer suggesties van patiënten niet goed passen binnen het referentiekader van de zorgprofessional of wanneer deze niet goed aansluiten bij de procedures binnen de organisatie. Bijvoorbeeld bij lichamelijke klachten waar (nog) geen diagnose kan worden gesteld, wanneer patiënten zorg vragen die volgens de arts niet nodig is of minder urgent is, of wanneer bepaalde zorg door een andere arts is toegezegd. Of wanneer patiënten fouten opmerken die zorgverleners liever niet maken. Juist in die situaties wél luisteren naar de patiënt maakt zorg tot goede zorg.

Serieus nemen betekent niet dat de patiënt gelijk moet krijgen. Maar wel dat zijn of haar inbreng wordt gehoord, en dat assertieve patiënten niet worden weggezet als lastig en veeleisend. Goede zorg betekent dus ook dat het ziekenhuis een actieve rol van patiënten accommodeert. Ook omdat niet elke patiënt op elk moment mondig kan zijn.

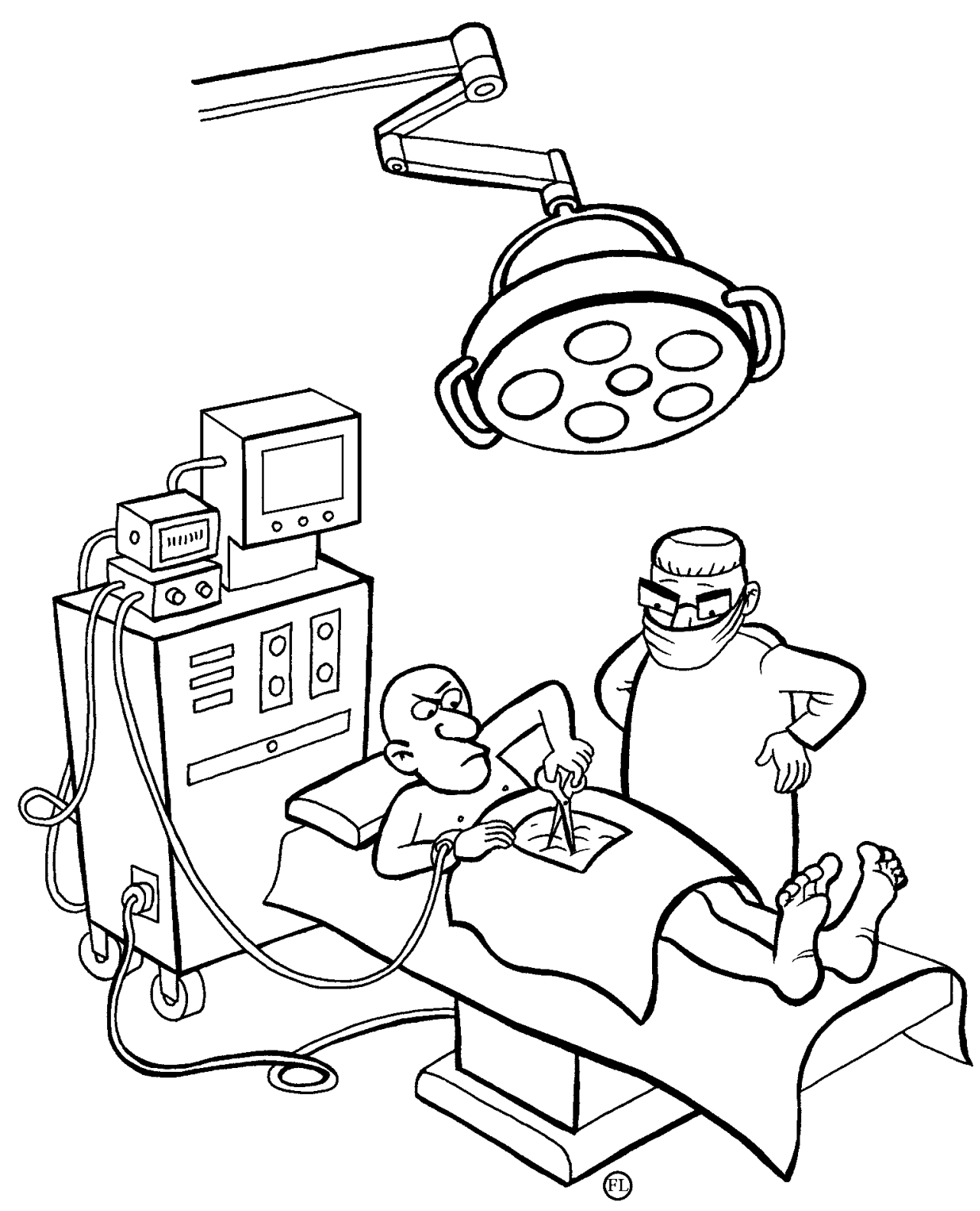




\section{Onmondig in het ziekenhuissysteem}

\subsection{Patiëntenervaringen}

In de onderstaande verhalen speelt onmondigheid die patiënten kunnen ervaren in het ziekenhuis een grote rol. In verhaal 6 komt een patiënt aan het woord die voor een onderzoek of behandeling naar het ziekenhuis moet. Gedurende het onderzoek of de behandeling krijgt de patiënt het onprettige gevoel dat de arts (medische professional) niet meer op een professionele wijze handelt. De patiënt wil dat het stopt, maar durft er toch niets van te zeggen en doet wat de arts haar vraagt. Achteraf houdt zij er een vervelend gevoel aan over. Ze baalt ervan dat het onderzoek op deze manier is verlopen, ze wil weten of dit al dan niet de normale gang van zaken is en heeft spijt niets te hebben gezegd tijdens de behandeling.

In het zevende verhaal worden de patiënt en zijn naasten tegen de verwachtingen in slachtoffer van de zorg. De personen in dit verhaal vertrouwen er in eerste instantie op dat er in het ziekenhuis goed voor de man wordt gezorgd. Dit wordt in het ziekenhuis ook bevestigd: "Maakt u zich geen zorgen, alles komt goed." Helaas gaan er tijdens de opname dingen grondig mis. De partner van de patiënt wordt hierdoor overdonderd en voelt zich machteloos, en omdat niet naar haar wordt geluisterd, staat ze machteloos. Uiteindelijk loopt het slecht af met de patient.
Verhaal 6:

De patiënt voelt zich niet geïnformeerd en onmondig bij

een onprettige behandeling

\section{Spijt dat ik zweeg over onprettige ervaring}

Omdat ik hartklachten had, werd een echo gemaakt van mijn hart en moest ik een fietsproef doen. Mijn huisarts verwees me door en ik kreeg een formulier mee. Maar over het onderzoek zelf kreeg ik geen enkele informatie, mondeling noch schriftelijk. Ik wist daardoor niet hoelang het zou duren en wat ik kon verwachten. Gelukkig kwam ik zelf op het idee een sportbroek mee te nemen. Dat bleek een goed idee, zag ik later in de folder in de wachtkamer.

Voor de echo moest ik mijn bovenlichaam ontbloten en op een bed gaan liggen. "Gaat u maar op uw linkerzij liggen en schuift u maar zo ver mogelijk naar de rand van het bed, dan kan ik ernaast zitten," zei de man die mij onderzocht. En zo geschiedde. Hij ging naast mij op het bed zitten tegen mijn rug aan. Ik kon niet zien wat hij deed, omdat het apparaat achter mij stond. De echo duurde een halfuur. Dus een halfuur lang zat de man naast mij op het bed tegen mij aan. Ik vond dit helemaal niet prettig, maar zei er niets van. Daar heb ik achteraf wel spijt van. Ik had moeten vragen of hij niet op een kruk kon gaan zitten.

LiHo

Verhaal 7:

De patiënt of partner is onmachtig in een (falend) zorgproces

\section{Mijn man kreeg geen goede hulp en is overleden}

Mijn man van 61 had last van hoge bloeddruk en gebruikte daarvoor tabletten. Toen kreeg hij last van galsteentjes. Omdat de pijnaanvallen met regelmaat terugkwamen, werd besloten tot een operatie. Volgens de arts was het een eenvoudige ingreep. Mijn man zou een nacht in het ziekenhuis moeten blijven en de dag na de operatie weer thuiskomen.

Hij werd geopereerd op 2 juli. Toen ik later die middag belde, werd me verteld dat hij terug was van de operatie en dat alles goed was verlopen. Mijn kinderen en ik mochten 's avonds op bezoek komen. De dag daarop mocht mijn man naar huis. Maar thuis was hij moe en had nergens zin in. 
Ook klaagde hij over pijn. Hij ging naar bed en wilde niet eten. De pijn werd steeds erger.

's Avonds belde ik de Huisartsenpost. De dokter zei dat mijn man de pijnstillers van het ziekenhuis moest gebruiken, maar die hielpen niet. Mijn man werd misselijk en begon over te geven. In een poging uit bed te komen, is hij gevallen en bewusteloos geraakt. Met moeite heb ik hem terug in bed kunnen helpen. Toen ik de Huisartsenpost nog een keer belde om noodhulp, kwam de dokter meteen. De darmen van mijn man bleken niet te werken. Omdat het ernstig was, werd mijn man met spoed naar het ziekenhuis gebracht. Daar werd hij in een bed op zaal gelegd. De arts-assistent kwam langs voor een infuus. Op mijn vraag wanneer de chirurg die hem had geopereerd zou komen, vertelde ze dat alles in orde was en dat ze al contact hadden gehad. Mijn man heeft daar de hele nacht gelegen, zwetend van pijn. Hij was met spoed naar het ziekenhuis vervoerd, maar eenmaal in het ziekenhuis was alle spoed totaal verdwenen.

Ik heb de hele nacht bij hem gezeten. Rond acht uur 's morgens kwam de chirurg bij hem kijken. Hij heeft mijn man niet eens aangeraakt. Volgens deze arts was het niets ernstigs: "Het kan een steentje zijn dat is achtergebleven." Mijn man werd opgenomen op de afdeling Chirurgie. Omdat ik niet bij hem mocht blijven, ging ik samen met mijn dochter naar huis. Later, tijdens het bezoekuur, bleek dat hij nog meer pijn had. Hij had een infuus en kreeg een katheter in zijn blaas. Maar hij plaste niet. Om één uur 's middags was de specialist nog niet bij hem geweest en had hij ook nog geen echografisch onderzoek gehad.

Toen we 's avonds op bezoek kwamen, merkte ik dat het helemaal mis was met hem. Mijn man had enorme pijn en was kortademig. In mijn hart kreeg ik de angst om hem te verliezen. De dag daarop vroeg ik in de verplegerspost of ik de arts van mijn man mocht spreken. Het antwoord was: "Mevrouw, daar hebben we geen tijd voor, we zijn met weinig en hebben veel patiënten. Als $u$ de arts van uw man wilt spreken, moet $u$ het zelf uitzoeken." Toen ik me omdraaide, hoorde ik dezelfde verpleegster zeggen tegen haar collega: "Dat soort mensen moet je kort houden. Ze zijn erg vervelend."

Ik ging zelf naar de polikliniek om de chirurg van mijn man te spreken. Maar ik kreeg hem niet te zien, ondanks mijn aandringen. lk was erg bang dat mijn man zou sterven. Later op de dag belde de chirurg mij: "Mevrouw, uw man krijgt de beste behandeling die er is. Alles is in orde, maakt u zich geen zorgen. Ik zorg dat hij morfine tegen de pijn krijg."
Maar 's avonds zag mijn man er grauw en erg ziek uit. Hij kon nog steeds niet goed ademen. Na bloedonderzoek werd hij naar de intensive care gebracht. Waarom weet ik niet. Niemand kon of wilde mij zeggen wat er aan de hand was. Op de intensive care was geen plaats, dus werd mijn man teruggereden naar de afdeling. Om zes uur in de ochtend werd ik gebeld door de intensive care dat ik snel moest komen met mijn kinderen.

Ik trof mijn man met een zuurstofmasker. Hij kon niet ademen.

Pas 's middags kwam de internist. Hij besloot mijn man te intuberen.

Ik moest naar buiten en heb afscheid genomen van mijn man. Hij pakte mijn handen vast en zei: "Ik ben niet bang om dood te gaan. Ik houd zielsveel van jou." Dat waren zijn laatste woorden. Hij werd geïntubeerd en in coma gebracht. Toen we weer bij hem mochten, lag hij aan allerlei slangen en apparaten. Nog een paar dagen heeft hij in die miserabele toestand gelegen. Op 13 juli is hij gestorven. Desondanks lukte het me niet om de specialist te spreken te krijgen.

Na de crematie hebben we besloten een klacht in te dienen bij de Inspectie. Die klacht is gelukkig serieus genomen. Ik hoopte dat daardoor de zorg en de communicatie binnen het desbetreffende ziekenhuis zouden verbeteren. Jammer genoeg hoor ik nog vaak dat daar dezelfde fouten worden gemaakt. Mijn grootste verdriet is dat er geen internist bij hem is geweest, toen mijn man naar de intensive care werd gebracht. Hij kreeg geen hulp. Tot er niets meer aan te doen was.

Sinhazinha

\subsection{Onmondigheid}

\section{Ongewenste intimiteit}

Hoewel intimiteit en de schending daarvan niet vaak lijken te worden besproken als het gaat om ziekenhuisbehandelingen, werd dit in de verhalen juist vaak benoemd als een belangrijk onderdeel van de beleving van de zorg. Er werd regelmatig opgemerkt dat het moeilijk is om erover te praten. Uit de verhalen blijkt dat veel handelingen in het ziekenhuis onder de noemer 'ongewenst' kunnen vallen, zoals uitstrijkjes maken van de baarmoederhals of echoscopieën maken van de darm. Ook meer alledaagse zaken als plassen in een po op de zaal, een douche delen of slapen met vier of meer mensen op een kamer kunnen erg intiem zijn en soms te intiem om te delen met anderen. Mensen ondergaan het, omdat ze denken er beter van te worden. 
Voor veel patiënten is het onduidelijk hoe een noodzakelijke (en toch ongewenste) intimiteit te onderscheiden is van een niet-noodzakelijke (en ongewenste) intimiteit. Gezien de verhalen is het voor veel patiënten moeilijk op dit gebied een goed evenwicht te vinden. Nog moeilijker is het om het onderwerp ter sprake te brengen. De vraag is altijd waar de grens ligt: bij welke mate van schending van je intimiteit en privacy moet je je neerleggen en wanneer mag of moet je het ter discussie stellen? Daarnaast is de meer formele vraag: welke normen en richtlijnen hanteren ziekenhuizen zelf ten aanzien van intimiteit? Hoe kun je je als patiënt hierover informeren? En welke eisen mag je stellen?

Het echte probleem in het zesde verhaal lijkt in de eerste plaats dus niet de onvolledige informatievoorziening, maar dat de patiënt in deze situatie niet in staat is te zeggen dat de situatie onprettig aanvoelt. Zij weet niet goed wat de betekenis is van het handelen van de zorgprofessional. Gaat deze een grens over of hoort het zo? De patiënt weet niet wat normaal is volgens het medische protocol. Vervolgens weet ze ook niet goed hoe zij het ongemak over de geschonden intimiteit moet aankaarten of welke middelen zij kan inzetten om de situatie te bespreken of zelfs te stoppen. Hier is dus sprake van onmondigheid.

\section{Niet gehoord}

Het probleem in het zevende verhaal is dat aan de hulpvraag van de echtgenot om in te grijpen na de onverwacht ontstane urgente conditie van haar man niet werd voldaan. Zij signaleerde dat het niet goed ging met haar man en dat hij hulp nodig had. In plaats daarvan werden haar aanhoudende hulpvragen beantwoord met traag, ontbrekend en niet respectvol handelen van de medische personages in het verhaal. Bovendien kreeg ze het gevoel dat zij een lastige persoon was doordat er achter haar rug maar binnen gehoorsafstand werd gezegd: "Dat soort mensen moet je kort houden. Ze zijn erg vervelend." Maar de uitkomst was dat de patiënt niet tijdig en niet goed geholpen werd en zijn medische situatie verslechterde, hoewel zijn vrouw veel pogingen deed dit onder de aandacht te brengen van medisch personeel. Dit leidde ertoe dat de echtgenote, die aanvankelijk vol vertrouwen was over een goede afloop, steeds wanhopiger en machtelozer werd. De patiënt overleed en de echtgenote en haar kinderen raakten daarmee het vertrouwen in dit ziekenhuis kwijt.

7.3 De rol van het ziekenhuissysteem bij onmondigheid De situatie waarin de patiënt - of zijn naaste - niet gehoord wordt of zichzelf niet laat horen, komt in veel verhalen terug. Naast de bovenstaande voorbeelden zijn er ook verhalen van patiënten die aangeven ergens pijn te hebben of denken een verkeerd medicijn te krijgen, maar niet serieus genomen worden als zij dit aankaarten. Dan komt het voor dat mensen ontmoedigd raken en ook de volgende keer niks meer zeggen. Ze voelen zich geïntimideerd, denken dat ze ongelijk hebben of willen de relatie met de zorgprofessionals niet verstoren. Patiënten zijn immers afhankelijk van de goede zorgen van anderen.
Maar dergelijke situaties leiden wel tot ontevreden patiënten en zijn soms ook de reden om het verhaal te schrijven.

Zorgprofessionals zien dit wel en proberen patiënten te bewegen tot meer mondigheid. In de workshop met de verpleegkundigen bleek dat sommige verpleegkundigen patiënten stimuleren om meer vragen te stellen aan artsen. En ook in de workshop met de vertegenwoordigers van patiëntenverenigingen wordt gesteld dat patiënten vaak veel te onmondig zijn.

Tegelijk merken zowel de artsen in opleiding als de verpleegkundigen en de ervaren artsen in de workshops meermaals op dat ook zij maar meedraaien in het systeem. Een van de artsen zegt: "Je ziet dat niet alleen de patiënt vastloopt in die bureaucratie, maar wijzelf ook." Recent onderzoek naar fouten in ziekenhuizen, zoals dat van Klein (2010), Gawande (2008) en anderen, laat zien dat fouten van enkele individuen meestal worden gefaciliteerd door het systeem Afgezien van de enkele incompetente persoon is een medische fout meestal een gevolg van een samenspel aan organisatorische, professionele en relationele factoren. Een goed ziekenhuissysteem zou (structureel) slechte prestaties van individuen moeten bemoeilijken. Uiteraard bestaan er programma's die inzetten op het verbeteren van zorgprocessen zoals Plain Tree en het Veilig Melden Systeem, die duidelijk resultaat hebben opgeleverd. In dergelijke programma's zijn patiënten belangrijk als extra paar oren en ogen.

\subsection{Goede zorg is: goed luisteren, goed informeren}

\section{en de partner serieus nemen}

Uit beide verhalen wordt duidelijk dat goede zorg voor deze patiënten gaat over goed luisteren, goed informeren en goed communiceren. Het verhaal over de ongewenste intimiteit maakt duidelijk dat er blijkbaar verschillen bestaan in beleving tussen zorgverleners en patiënten over wat (on)gewenste intimiteit is. En dat het belangrijk is die verschillen in beleving te kennen. Wat voor de actoren in een ziekenhuis vanzelfsprekend is, is dat nog niet voor patiënten. Patiënten stellen het daarom op prijs om precies geïnformeerd te worden over wat ze kunnen verwachten, zeker in het geval van lichamelijk intiem onderzoek, en hebben behoefte aan kennis over wat in deze precaire medische situatie normaal is.

Dat betekent ook dat artsen en verpleegkundigen alert moeten zijn op wat mogelijk ongewenst kan zijn voor een patiënt, of dat ze aanvullende informatie geven tijdens het onderzoek. Patiënten moeten daarnaast in staat worden gesteld om onprettige situaties aan te geven tijdens of na afloop van een behandeling of onderzoek. Kortom, ziekenhuizen en zorgverleners moeten aandacht hebben voor mogelijke onprettige ervaringen, ook bij protocollair juiste behandelingen. Het verhaal waarschuwt ervoor erop te letten de patiënt als persoon te blijven zien, niet als een lichaam dat onderzocht moet worden. 
We kunnen uit het verhaal van de falende zorg niet opmaken of sneller handelen het overlijden van de patiënt had kunnen voorkomen. Maar we kunnen wel leren hoe belangrijk het is dat naasten serieus genomen worden als gesprekspartner en dat respect getoond wordt voor de ongerustheid van patiënten en van naasten. Goede zorg bestaat uit goede communicatie met de patiënt en/of naasten over (wijzigingen in) de medische procedure, ook, of misschien vooral, als de patiënt niet zo goed Nederlands spreekt. En goede communicatie is ook dat de patiënt duidelijkheid krijgt over wat er gedaan wordt met de klachten.

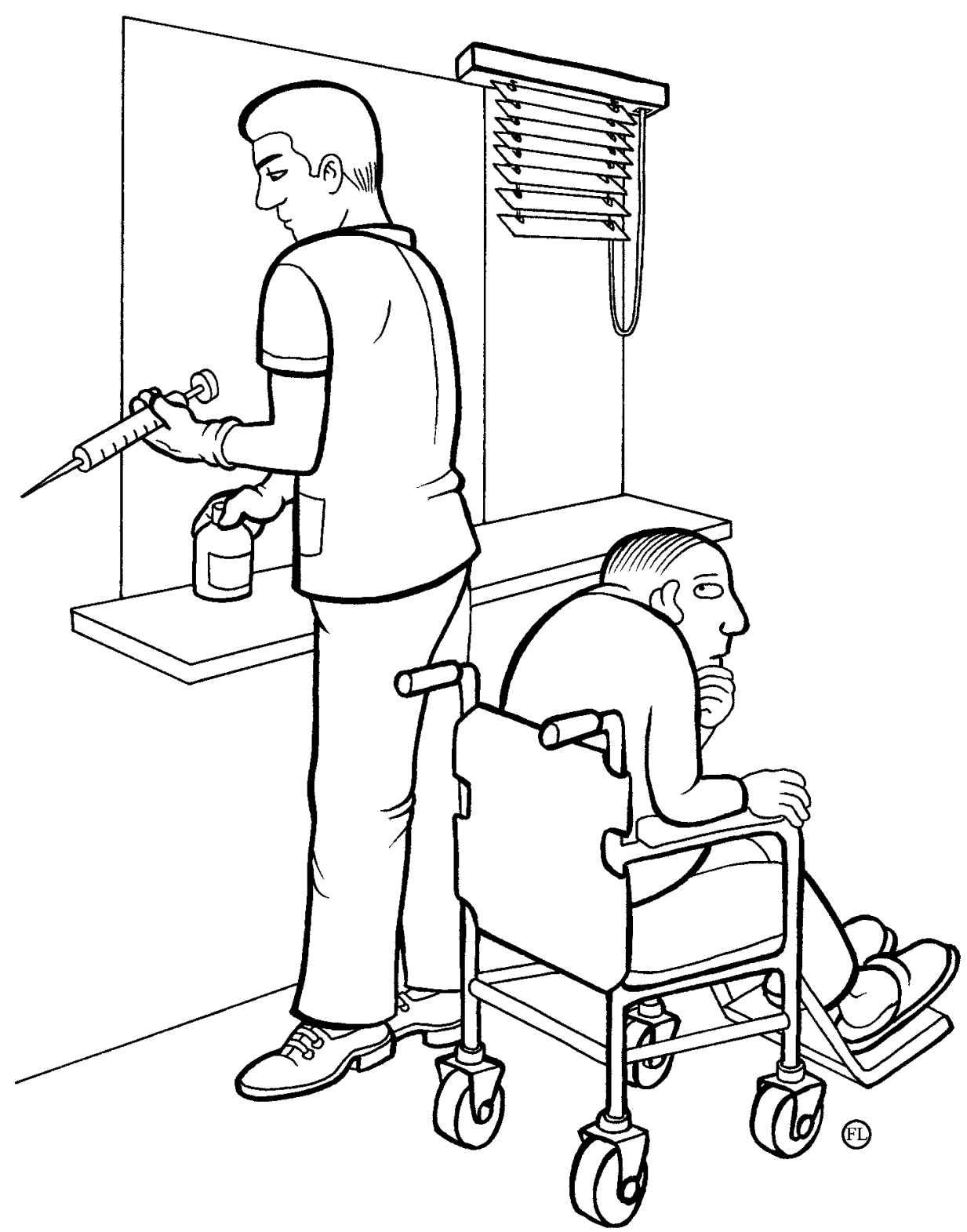




\section{Onbekende verwachtingen, bij patiënten én zorgverleners}

\subsection{Patiëntenervaringen}

In de laatste twee verhalen benoemen twee mensen expliciet hun verwachtingen over de zorg in het ziekenhuis. Uiteraard lenen alle verhalen zich goed om erachter te komen wat mensen verwachten van ziekenhuiszorg. Deze twee verhalen benoemen het ook expliciet.

Het achtste verhaal vertelt een ervaring van een persoon die onverwacht in het ziekenhuis belandt en vanwege twee handen in het gips totaal afhankelijk is van de zorg die daar wordt geboden. In het ziekenhuis is iedereen druk doende met van alles, maar is er niet echt oog voor de zorgafhankelijke situatie van deze persoon en alles wat daarbij komt kijken. Deze persoon raakt teleurgesteld in de zorgverlening, zowel in het ziekenhuis als in het thuiszorgtraject daarna, omdat de zorg in haar ervaring op verschillende fronten tekortschiet. Hierdoor heeft zij de periode in het ziekenhuis en de periode van nazorg als onprettig ervaren en voelde zij zich niet goed geholpen. Ze vindt het jammer dat ze deze negatieve ervaring heeft meegemaakt. Ze zou willen dat er meer aandacht en zorg zou zijn voor mensen die in een dergelijke situatie zitten.

In verhaal 9 moet de hoofdpersoon na een ongeluk naar het ziekenhuis. Hij is op het ergste voorbereid en verwacht een erg onprettige ervaring, waarvoor hij ergens ook begrip heeft. Eenmaal in het ziekenhuis heeft deze persoon juist heel goede ervaringen; er is aandacht voor de persoon achter de patiënt en de compleetheid van zorg valt op. Op grond van deze goede ervaringen stelt deze persoon zijn beeld van een verblijf in het ziekenhuis positief bij.
Verhaal 8

De patiënt voelt zich in de steek gelaten door gebrek aan goede zorg

\section{Hoe kon de nazorg zo slecht zijn?}

Bij een valpartij over een stoeptegel liep ik een open botbreuk op aan mijn linkerpink. Na een foto en de nodige spuiten op de Eerste Hulp trok en draaide de dienstdoende arts met veel geweld aan mijn pink. Het lukte hem niet het bot te zetten. Daarom werd ik nog diezelfde avond geopereerd. Nu had ik de pech dat ik een paar weken eerder mijn rechterpols en duim ernstig had gekneusd. Die zaten nog in een gipsspalk. 's Morgens werd ik dus wakker met twee handen en onderarmen in 't gips.

De arts aan mijn bed keek naar mijn vingertoppen en zei, meer tegen de verpleegkundige dan tegen mij: "Geen verkleuring, geen zwelling, geen tinteling: mevrouw mag naar huis." De verpleegkundige stelde meteen voor te helpen met aankleden. Nog niet helemaal helder door de narcose besefte ik de draagwijdte van de boodschap van de arts niet meteen, maar vroeg toch: "Hoe moet dat dan thuis met wassen,

aankleden en eten?" De transferverpleegkundige zou zorgen dat ik thuis hulp kreeg bij het douchen en aan- en uitkleden.

Eenmaal thuis bedacht ik dat ik beter naar een zorghotel had kunnen gaan. Maar dat had ik in het ziekenhuis moeten regelen of veertien dagen eerder moeten aanvragen! Toen de verzorgster weg was, kreeg ik honger, dorst en pijn. Maar wat dacht je? Met twee handen in het gips kon ik helemaal niets! Niet naar de wc, geen kast of kraan openen, geen brood smeren of een kopje koffie zetten. Zelfs de zetpillen tegen de pijn kreeg ik niet uit de verpakking, laat staan ingebracht.

Leve de telefoon waar ik maar op één knop hoefde te drukken om mijn dochter aan de lijn te krijgen. Die kwam gelukkig ontbijt maken en regelde dat Thuiszorg 's morgens het ontbijt voor mij zou maken. Helaas ging dat niet zomaar: het had schriftelijk moeten worden aangevraagd en het kon tien tot veertien dagen duren voor de aanvraag werd gehonoreerd! Toen ik vroeg of de mijnheer van de Thuiszorg ook veertien dagen wachtte met ontbijten, zei hij dat ik niet zo cynisch moest zijn.

I vind dat het ziekenhuis mij nooit zo naar huis had moeten laten gaan. Bij navraag bleek de transferverpleegkundige aan niet meer te hebben gedacht dan wassen en eten. Ze dacht dat daarmee alles geregeld was. 
Het genezingsproces verliep ook helemaal niet zoals het ziekenhuis had verwacht. Toen het gips weg was, bleef mijn linkerhand dik, rood en pijnlijk en ook de rechterpols wilde niet echt vooruit. De arts in het ziekenhuis zei dat ik meer pijnstillers moest slikken en geduld moest hebben. Hij dacht ook dat mijn boosheid het genezingsproces in de weg zat. Bij een bezoek aan een andere arts bleek echter dat de vingers niet goed waren gezet en dat het waarschijnlijk ook niet meer goed zou komen. Inmiddels probeer ik door training bij de fysiotherapeut mijn spieren sterker te maken, zodat ik weer kan fietsen en na een tijdje hopelijk autorijden.

Het is nu een jaar later en ik kan nog steeds niet van me afzetten hoe de nazorg zo slecht kon zijn. Er was bij mij weliswaar geen sprake van een levensbedreigende kwestie, maar de impact op mijn leven was - en is nog steeds - groot. Door al die misverstanden, dat onbegrip en die miscommunicatie ben ik er behoorlijk overspannen van geweest. Hoop dat dit niemand overkomt

Nelly, weduwe, 72 jaar
Verhaal 9

De patiënt heeft een goede ervaring ondanks lage verwachtingen

\section{Onder de indruk van aandacht op Eerste Hulp}

$\mathrm{Na}$ een middag skaten door de stad waren we toe aan het laatste stuk door de duinen. Aan het einde van de rit maakte ik een flinke smak in een steile bocht. Twee ambtenaren die klaarstonden om bonnen uit te delen aan scooters, verleenden eerste hulp en brachten me met hun auto naar de Eerste Hulp van het ziekenhuis. In de auto maakten ze me bang: misschien zouden ze mij bij de Eerste Hulp wegsturen, naar de Huisartsenpost.

Zelf had ik ook de nodige doemscenario's in gedachten over de Eerste Hulp: een enorme wachtkamer vol met mensen, eindeloos wachten en personeel dat onder tijdsdruk staat en daardoor snel en zonder veel persoonlijke aandacht zou handelen. Daarbij: ik was wel flink gevallen, maar geen spoedgeval. Zo zou ik ook behandeld worden, verwachtte ik.

Niets was minder waar. De receptioniste was erg vriendelijk en bood ons drinken aan. De wachtruimte was wel vrij klein, maar niet overvol. Er was voldoende afleiding voor kinderen, er hing een televisie en op een ander scherm stond informatie voor patiënten.

$\mathrm{Na}$ korte tijd werden we ontvangen door een verpleegkundige. Het vie me niet alleen op hoe professioneel ze omging met mijn verwondingen, maar ook hoe meelevend ze reageerde. En dat terwijl ze waarschijnlijk dagelijks ergere dingen zag. Nadat ze mijn verwondingen had behandeld, kreeg ik een tetanusprik. Daarna wachtte ik weer in de wachtkamer tot ik werd opgehaald door een arts.

Ook bij hem viel me op dat hij niet alleen aandacht had voor mijn medische verhaal, maar ook voor mij, als mens. Dat zat hem onder meer in kleine opmerkingen en vragen: dat ik toch wel pech had gehad, of mijn vriendin die nog in de wachtkamer zat echt niet mee wilde en of ik op het bed of op de stoel wilde zitten. Naast de goede medische verzorging maakte de manier waarop ik werd behandeld indruk op me. Men had echt aandacht voor me had en toonde inlevingsvermogen zonder dat dit nu veel onnodige tijd in beslag nam.

Een skater, 28 jaar 
8.2 Wat verwachten patiënten van het ziekenhuis?

De schrijvers van beide verhalen schetsen een duidelijk beeld van wat kwalitatief hoogwaardige en complete zorg is. Daarbij wordt een aantal aspecten van goede zorg genoemd. In het ene verhaal zijn die aspecten daadwerkelijk (deels) aanwezig, in het andere wenst de patiënt graag dergelijke zorg.

Vanwege haar afhankelijke positie probeert de mevrouw in verhaal 8 hulp te krijgen bij het regelen van zorg, onder meer de thuiszorg. Het ziekenhuis regelt echter op onvoldoende terreinen hulp, alleen voor douchen en aankleden, terwijl de mevrouw ook hulp nodig heeft voor brood smeren, koffie zetten, toiletbezoek en dergelijke. Wanneer de dochter het regelen van thuiszorg op zich neemt, werken bureaucratische regels tegen. Het doel - herstellen van de val wordt door de zorgverleners anders ingevuld dan door de patiënt zelf. De zorgverleners verlangen geduld, terwijl de patiënt ondersteuning bij de dagelijkse verzorging als middel ziet om goed te kunnen herstellen. Zij kan immers niet veel zelf, ook geen eten en drinken klaarmaken.

De situatie in verhaal 9 is te vergelijken met de dame in verhaal 2, die vooral de human touch van de verzorging is bijgebleven. In beide situaties wordt goed voor de patiënt gezorgd en kan de patiënt zich met een gerust hart overgeven aan de zorg. Het verschil is dat in het negende verhaal de skater binnenkwam met lage verwachtingen en dat ook expliciet meldt. Dat lijkt ook de reden om dit verhaal te vertellen.

\section{Complete zorg: goede medische zorg én aandacht voor de persoon}

Uit het verhaal van de gevallen skater halen we dat complete zorg bestaat uit aandacht voor het comfort en de bejegening van de patiënt; in aanvulling op een goede medische behandeling. Van belang is een vriendelijke ontvangst; het wachten in een prettige omgeving, aandacht voor service, afleidingen en informatie. Bovendien is het professioneel medisch handelen voor de patiënt erg belangrijk met informatie over nazorg en dat er naast medische zorg aandacht en meelevendheid is voor de persoon.

In het verhaal van de vrouw met beide handen in het gips worden deze elementen specifieker benoemd. Zij noemt als goede zorg dat niet alleen zorg wordt gedragen voor de medische klacht, maar ook voor het regelen van goede nazorg. Dat neemt zorgen weg bij de patiënt over hoe het thuis moet. En wanneer het genezingsproces niet verloopt zoals verwacht, is het van belang dat hierover met de patiënt goed wordt gecommuniceerd en dat de schuld voor de trage genezing niet bij het ongeduld en boosheid van de patiënt wordt gelegd. Het is een van de redenen dat de vrouw een andere arts opzoekt. Goede zorg is naar haar mening bovendien niet beperkt in tijd en plaats. (Thuis)zorg moet niet onnodig worden beperkt door allerlei omslachtige bureaucratische regels. Goede zorg bestaat uit goede medische zorg met daarnaast aandacht, inlevingsvermogen en een goede bejegening.
8.3 Spanning tussen verschillende verwachtingen van zorgverleners en patiënten

Wat we uit de verhalen opmaken is dat bejegening verdergaat dan aardig zijn. Het gaat erom dat mensen zich serieus genomen voelen in hun angsten, hun wensen en gewenste rollen in het zorgproces en in hun verwachtingen over de zorg. Uiteraard betekent dat niet dat alle wensen ingewilligd moeten worden. Het betekent wel dat mensen het recht hebben gehoord te worden, het recht hebben op een eerlijk antwoord en het recht hebben op realistische verwachtingen. Als dat niet lukt, kan er spanning ontstaan tussen de patiënt en de zorgverlener. Deze spanning kan doorwerken in latere fasen van het zorgproces.

In het geval van de onthande vrouw ontstond een negatieve dynamiek tussen de patiënt en de zorgverleners, die leidde tot slechtere zorg.

Een dergelijke negatieve dynamiek tussen de patiënt kan leiden tot slechtere zorg (Chang 2012; Higgins \& Bargh 1987; Macfarlane et al. 1997; Bensing 2006). Bovendien lopen 'lastige' patiënten een grotere kans op slechtere zorg

(Macfarlane et al. 1997; Gawande 2008), omdat zorgverleners de neiging hebben minder vaak binnen te lopen bij patiënten die ze als lastig ervaren, en ook hun klachten minder serieus te nemen. Dat komt terug in de workshops met de ervaren artsen. Die merken ook op dat patiënten vaker terugkomen als ze zich onbegrepen voelen.

Een ander probleem is dat ontevredenheid over verleende zorg kan leiden tot wantrouwen bij zorgverleners enerzijds en angst voor een volgend ziekenhuisbezoek en vermijdingsgedrag bij patiënten. Deze angst en dit verlies aan vertrouwen komt ook naar voren uit andere ervaringsverhalen.

Uit het onderzoek blijkt dat de spanning tussen patiënten en zorgverleners niet alleen voortkomt uit de verwachtingen van de patiënt, maar voor een deel ook te maken kan hebben met de verwachtingen die zorgverleners hebben van patiënten. Interessant genoeg bleek tijdens de workshop met de verpleegkundigen dat zij allen bepaalde verwachtingen hebben ten aanzien van het gedrag van patiënten. Als patiënten voldoen aan deze - vaak ongeschreven norm, is dat prettig voor zowel verpleegkundigen als patiënten. De verpleegkundigen gaven aan dan heus bereid te zijn ietsje meer hun best te doen.

Daar staat tegenover dat door meerdere verpleegkundigen werd opgemerkt dat de verwachtingen van patiënten de laatste jaren lijken toe te nemen en dat door patiënten (en soms ook anderen) wel erg veel van de verpleegkundige wordt gevraagd. Na doorvragen blijkt dit probleem ook groter te zijn geworden, omdat het aantal patiënten per verpleegkundige de afgelopen jaren is toegenomen; bij de genoemde verpleegkundige bijvoorbeeld van vier naar zeven. Met een toegenomen werkdruk blijft er uiteraard minder tijd per patiënt over, wat ertoe kan leiden dat vragen of verzoeken van patiënten niet goed vallen bij verpleegkundigen. Overigens zijn patiënten zich daar vaak van bewust, zo blijkt 
ook uit de verhalen, en verwachten ze echt niet dat verpleegkundigen altijd direct voor hen klaarstaan.

\section{Wederzijdse positieve beïnvloeding}

Uit het onderzoek van Chang (2012) maar ook van Bensing et al. (2006) blijkt dat patiënten die tevreden zijn met eerdere zorg beter luisteren naar de boodschap van zorgprofessionals, die zij ook beter onthouden en interpreteren. Ook voegen zij zich beter naar een behandelregime. Dat leidt er ook toe dat zorgverleners zich behulpzamer opstellen. Een van de ervaren artsen in de workshop merkte op dat "een patiënt die meer weet, sneller herstelt". En dat kan weer leiden tot kortere opnames en tevredener patiënten. Kortom, de houding van zowel de patiënt als de zorgprofessional beïnvloedt het gedrag van beiden, waarbij positief gedrag een positieve reactie uitlokt.

8.4 Goede zorg is: realistische verwachtingen creëren

Als vaste 'bewoners' van het ziekenhuis zijn zorgverleners uiteraard goed

bekend met de procedures en de cultuur van een ziekenhuis. Maar de meeste patiënten zijn hiervan niet op de hoogte. Hoewel er bijvoorbeeld vaak van uit wordt gegaan dat mensen weten dat een specialist maar tien minuten per consult heeft, is het de vraag of iedere patiënt dit weet. Of misschien is de patiënt dit vergeten, zodra hij zelf in de spreekkamer zit. Dan voelt iemand zich na tien minuten weggebonjourd met onbeantwoorde vragen. Zo geldt dit voor vele processen in het ziekenhuis. De patiënt weet vaak niet wat te verwachten van de zorgverlening in een ziekenhuis en de verwachtingen die artsen en verpleegkundigen van patiënten hebben, worden vaak niet openlijk gedeeld met de patiënten. Juist daarom is het belangrijk in te zetten op een goede patiëntenervaring. Het creëren van realistische verwachtingen bij patiënten over de reikwijdte van ziekenhuiszorg kan daaraan zeker bijdragen.

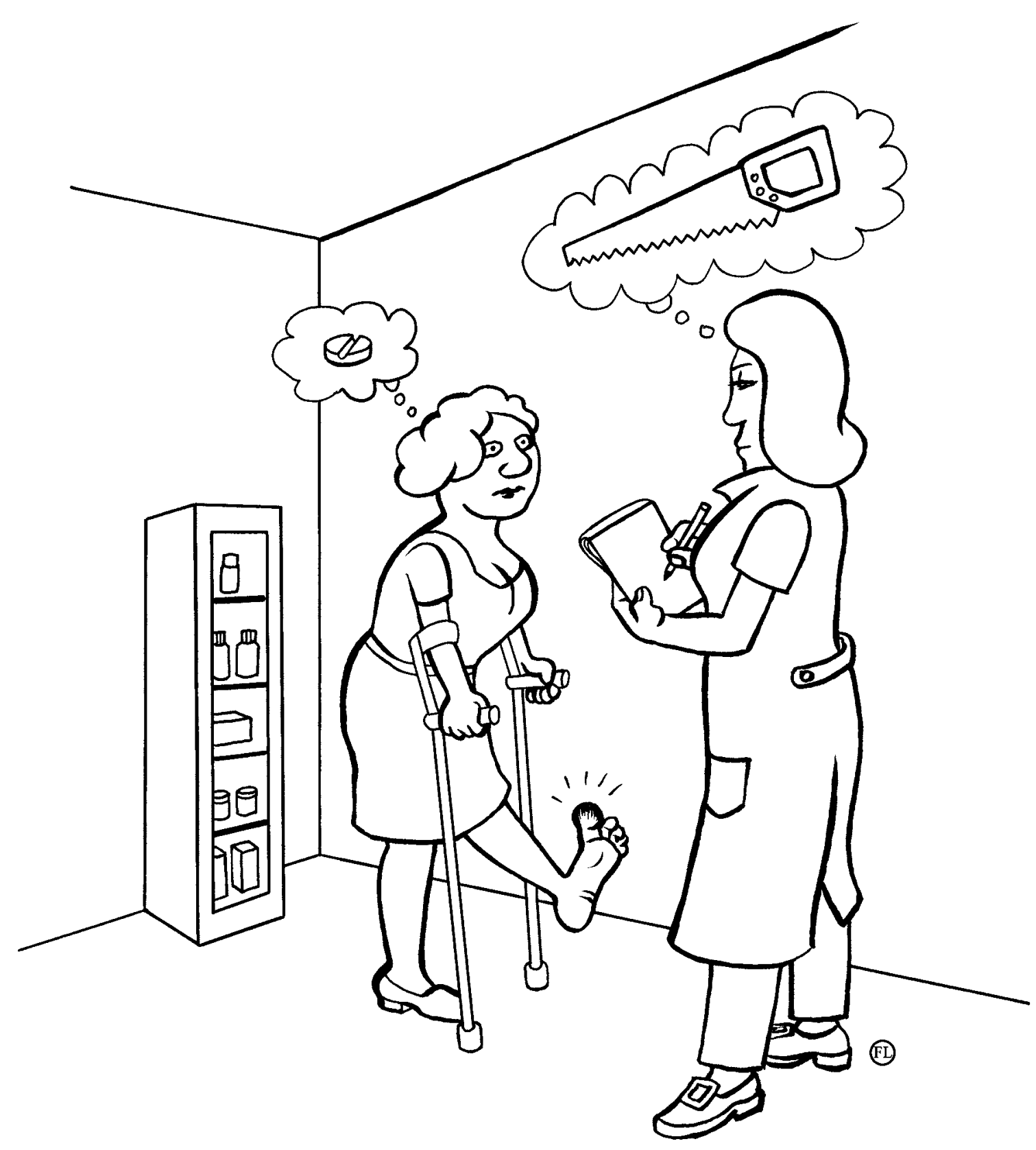




\section{Conclusies en aanbevelingen}

De ontwikkeling naar een sterkere positie van de patiënt in de zorg en de kritische geluiden op deze grotere rol van de patiënt roepen de vraag op hoe het zit met de mondigheid van patiënten: in hoeverre krijgen patiënten voldoende ruimte om zelf beslissingen te kunnen nemen en invloed te hebben op de zorg in ziekenhuizen? Hoe reëel is het idee van een sterke en mondige ziekenhuispatiënt? Het Rathenau Instituut heeft deze kwesties onderzocht via geschreven patiënten ervaringen. De volgende vragen stonden in deze studie centraal:

1. Hoe ervaren patiënten en hun naasten verleende ziekenhuiszorg?

2. Wat zeggen deze ervaringen over de rol van de mondige patiënt in het zorgproces?

3. Hoe kunnen deze ervaringen bijdragen aan het verbeteren van de kwaliteit van ziekenhuiszorg?

We zetten de antwoorden op deze vragen hier kort op een rij.

9.1 De mondige patiënt komt moeilijk tot zijn recht in het ziekenhuis Uit ons onderzoek blijkt dat de rol van mondige en kritische patiënt, zoals de overheid die lijkt te willen stimuleren, moeilijk tot zijn recht komt in het ziekenhuis. Dat wordt zichtbaar door alle thema's heen. Voor de patiënt is het ziekenhuis vaak een ongewone omgeving, waarin angst, wanhoop en informatieachterstand de boventoon voeren. Voor artsen en verpleegkundigen is het ziekenhuis een alledaags verschijnsel, namelijk hun werkomgeving. Bovendien staat in het ziekenhuis het medisch perspectief van de zorgprofessionals centraal. Dat gaat uit van de autonomie van de professional en van medische standaards en richtlijnen waarin (nog) weinig ruimte is voor een actieve bijdrage van de patiënt. Dat maakt patiënten vaak onmondig. De kritisch meedenkende patiënt moet bovendien opletten dat hij niet wordt weggezet als lastig en veeleisend en daardoor een tekort aan zorg krijgt. Dit kan ertoe leiden dat patiënten onmondiger worden dan nodig is, slechtere zorg krijgen of ontevreden raken en vaker terugkomen, of het vertrouwen in de zorg verliezen

\subsection{Obstakels voor mondigheid}

Uit onderzoek naar de vraag hoe patiënten en hun naasten verleende ziekenhuiszorg ervaren, blijkt dat een verblijf in het ziekenhuis geen neutrale ervaring is voor mensen. Het roept juist sterke gevoelens op, zo geven de ervaringsverhalen aan. Uit ons onderzoek blijken er tenminste negen gedeelde ervaringen te bestaan:

1. de patiënt ervaart onzekerheid en wanhoop over het leven met de aandoening;

2. de persoon voelt zich gesteund door een beetje extra hulp

3. de patiënt is de bewaker van goede zorg:

4. de patiënt of partner is coprofessional;

5. de patiënt ziet fouten in het systeem en raakt verontrust;

6. de patiënt voelt zich niet geïnformeerd en onmondig bij een onprettige behandeling

7. de patiënt of partner is onmachtig in een (falend) zorgproces;

8. de patiënt voelt zich in de steek gelaten door gebrek aan goede zorg;

9. de patiënt heeft een goede ervaring, ondanks lage verwachtingen.

Uit de verschillende onderdelen van het onderzoek verschijnen een aantal thema's die een rol spelen bij de manier waarop mensen vorm geven aan autonomie en mondigheid in het ziekenhuis of waarin zij juist belemmeringen ervaren. Hoe mondig mensen kunnen zijn in het ziekenhuis, hangt mede af van

\section{Onzekerheid of angst in een onbekende situatie}

Door ziekte, een aandoening of acute opname voelen mensen zich onzeker, angstig of wanhopig. Dat kan worden veroorzaakt door pijn, angst voor (mogelijk) overlijden of fysieke aftakeling, of het onbekende vooruitzicht te moeten leven met een ziekte. In veel verhalen zijn mensen eerst bezig om te gaan de onzekerheid en angst die een diagnose of ziekenhuisverblijf met zich meebrengt, om pas dan oor en oog te hebben voor andere zaken die spelen in het ziekenhuis.

\section{Moeizame waardering van mondige en actieve patiënten}

Veel patiënten of hun naasten stellen zich actief op in hun eigen ziekte en de zorg in het ziekenhuis. Dat doen zij om verschillende redenen: omdat men ervaringsdeskundig is en veel weet van het eigen lichaam en de ziekte, omdat mensen zich medeverantwoordelijk voelen voor goede zorg of omdat ze zich gedwongen voelen als bewaker van goede zorg op te treden doordat ze dingen in de zorg mis zien gaan. Deze actieve houding wordt niet altijd gewaardeerd of begrepen door zorgverleners, en kan er zelfs toe leiden dat patiënten als lastig worden weggezet. 


\section{Onmondig in het ziekenhuissysteem}

Veel mensen, zowel patiënten als naasten, voelen zich onmondig in het ziekenhuis, ook als men in het dagelijks leven een mondig persoon is. De organisatie van zorg in het ziekenhuis en de houding van sommige zorgprofessionals dragen bij aan deze onmondigheid. Mensen ondervinden dat ze slecht zijn geïnformeerd over procedures, diagnoses of behandelingen. Mensen ervaren ook dat artsen en verpleegkundigen weinig tijd en empathie hebben voor emoties. In sommige verhalen worden klagende patiënten genegeerd door zorgverleners. Mensen houden klachten of onvrede daarom vaak voor zich om niet te worden gezien als een lastige persoon.

\section{Onbekende verwachtingen - bij patiënten én zorgverleners.}

De verwachtingen van patiënten sluiten vaak niet aan bij wat het ziekenhuis te bieden heeft. Mensen weten niet wat ze kunnen verwachten of hebben juist lage verwachtingen van zorg in het ziekenhuis. Tegelijkertijd hebben zorgprofessionals bepaalde impliciete verwachtingen van patiënten. Dat kan leiden tot onverwachte positieve, maar vaker juist tot negatieve ervaringen bij patiënten.

\subsection{Patiëntenervaringen geven veel informatie over de}

\section{kwaliteit van ziekenhuiszorg}

Uit het onderzoek blijkt dat veel te leren is van patiëntenervaringen over de kwaliteit van ziekenhuiszorg. Patiënten hebben een duidelijke mening en visie op kwaliteit van zorg. Bovendien heeft die betrekking op zowel professionele, organisatorische dimensies als op relationele aspecten van kwaliteit van zorg. De patiënten die in dit onderzoek aan het woord komen, zien graag dat de zorg tijdig is, doelmatig, patiëntgericht, veilig en professioneel en naar behoefte, en dat komt overeen met de in de wet gestelde eisen aan goede zorg. De patiënten in dit onderzoek zien daarnaast dat de organisatie van zorgprocessen een belangrijk onderdeel is van goede en veilige zorg, bijvoorbeeld bij het op orde hebben van dossiers, de toediening van medicijnen, het op de juiste wijze ontslaan van patiënten uit het ziekenhuis en vele andere zaken.

Uit de verhalen komt naar voren dat goede zorg concreet betekent dat de zorgprofessional aandacht heeft, inlevingsvermogen, en de patiënt op de juiste manier bejegent. Patiënten verlangen ook graag aandacht voor de wanhoop en angst die zij kunnen ervaren als zij worden geconfronteerd met een plotselinge aandoening, ongeluk of andere aanleiding waarvoor een ziekenhuisopname nodig is. Goede zorg is voor patiënten dat zorgprofessionals goed luisteren naar wat patiënten te zeggen hebben over hun fysieke toestand en dat zorgprofessionals patiënten goed informeren over wat er gaande is en wat er verwacht kan worden van de diagnose, de eventuele testen, de behandeling, het verblijf in het ziekenhuis - ook als er (nog) niet veel over te zeggen valt. Bovendien houdt goede zorg in dat de partner of vertegenwoordiger van de patiënt serieus genomen wordt als gesprekspartner. 


\section{Literatuurlijst}

Barbour, R.S. (2001). 'Checklists For Improving Rigour in Qualitative Research. A Case of the Tail Wagging the Dog?' In: British Medical Journal 322, no. 7294 pp. 1115-1117.

Bensing, J. et al. (2006). 'Shifts in Doctor-Patient Communication Between 1986 and 2002. A Study of Videotaped General Practice Consultations with

Hypertension Patients'. In: BMC Family Practice 7, no. 62.

Berwick, D. (2013) 'Alleen lerende cultuur vergroot patiëntveiligheid'.

In: Zorgvisie, september 2013.

Binkhorst, T., E. Posma \& S. Lobenstein (red.) (2009). Patiënten betrekken bij de zorg in het ziekenhuis. Een handboek. Utrecht: Kwaliteitsinstituut voor de gezondheidszorg $\mathrm{CBO}$.

Bont, A., Jerak, S., Zuiderent, T., Bal, R. \& Meurs, P. (2009). Veiligheid in de zorg. Achtergrondstudie bij de Staat van de Gezondheidszorg 2009. Rotterdam: Instituut Beleid \& Management Gezondheidszorg.

Bovenkamp, H.M. van de. (2010). The Limits of Patient Power. Examining Active Citizenship in Dutch Health Care. Erasmus MC: University Medical Center Rotterdam. Thesis.

Bruner, J.S. (1990). Acts of Meaning. London: Harvard University Press.

Buikema, M. (2011). Onder zeil. Een reconstructie van een medische fout. Woubrugge: Zin Publishing.

Burke, K. (1945/1969). A Grammar of Motives. Berkeley et al.: University of California Press.

CBO (2013). 'Over het CBO'. http://www.cbo.nl/algemeen/Over-het-CBO, voor het laatst geraadpleegd 24 mei 2013.

CG-Raad, CSO, LPGGz, NPCF en Platform VG i.o.m. Zorgbelang Nederland. (2010). De stem van de cliënt. Notitie van CG-Raad, CSO, LPGGz, NPCF en Platform VG i.o.m. Zorgbelang Nederland. Utrecht.
CG-Raad (2013). 'Onze standpunten patiëntenzorg'. http://www.cg-raad.nl/ onze_standpunten/patientenzorg.php?okcookie=1, voor het laatst geraadpleegd 5 september 2013.

Chang, I.W. (2012). Patient Expectations for Healthcare Experiences Among the Taiwanese Population. Thesis.

Crul, B. (2007). 'Patiëntgericht'. In: Medisch Contact 62, p. 575

Haes J. de, L. Zandbelt \& L. Ong. (2006). 'Communicatie van arts en patiënt'. In: Kaptein et al. (red.). Medische psychologie. Houten: Bohn Stafleu Van Loghum, pp. 171-186.

Dijk, T. van. (2007). Medische Missers. En hoe die voorkomen hadden kunnen worden. Amsterdam: Nijgh \& van Ditmar.

Egmond, S. van (2010). Science and Policy in Interaction. Thesis.

Gawande, A. (2008). Better. A Surgeon's Notes on Performance. London: Profile Books.

Grit, K., H.M. van de Bovenkamp \& R. Bal. (2008). De positie van de zorggebruiker in een veranderend stelsel. Een quick scan van aandachtspunten en wetenschappelijke inzichten. Rotterdam: Instituut Beleid \& Management Gezondheidszorg.

Hendriks, A.C., Friele, R. D., Legemaate, J., \& Widdershoven, G. A. M. (2013). Thematische Wetsevaluatie. Zelfbeschikking in de zorg. Den Haag: ZonMw.

Higgins, E.T. \& J.A. Bargh. (1987). 'Social Cognition and Social Perception'. In: Annual Review of Psychology 38, pp. 369-425.

Hilders, C. (2013). 'Specialist en patiënten moeten time-out nemen'. In: Zorgvisie, augustus 2013

Inspectie voor de GezondheidsZorg (IGZ) (2009). Staat van de gezondheidszorg 2009. De vrijblijvendheid voorbij. Sturen en toezichthouden op kwaliteit en veiligheid in de zorg. Den Haag: IGZ.

Institute of Medicine. Committee on Quality of Health Care in America (2001). Crossing the Quality Chasm. A New Health System for the 21st Century. Washington D.C.: National Academy Press. 


\section{Kamerstukken I, 2013, 33243, C.}

Kamerstukken II, 2012, 32402, nr. 9 .

\section{Kamerstukken II, 2011, 32402, nr. 6}

Klein, J., Tussen de modder van de praktijk en de schone wetenschap, 26 november 2010. Rotterdam: Instituut Beleid \& Management Gezondheidszorg.

Kleinman, A. \& D. Seeman. (2000). 'Personal Experience of Illness'. In: Albrecht et al. (eds.). Handbook of Social Studies in Health and Medicine. London: Thousand Oaks, pp. 230-242.

Kohn, L.T., J.M. Corrigan \& M.S. Donaldson (eds.). (2000). To Err Is Human. Building a Safer Health System. Washington D.C.: Institute of Medicine Committee on Quality of Health Care in America.

Koninklijke Nederlandsche Maatschappij tot bevordering der Geneeskunst (KNMG). (2001). Informed Consent. Versie 3.0. Utrecht: KNMG.

Korte, J., G.J. Westerhof \& E.T. Bohlmeijer. (2012). 'Mediating Processes in an Effective Life Review Intervention'. In: Psychology and Aging 27, no. 4, pp. 1172-1181.

Lelie, A. (1999). Ethiek en nefrologie. Een empirisch-ethisch onderzoek. Leende: Damon.

LSR, NPCF, Zorgbelang Nederland \& CBO. (2006). Cliëntenraden, gedoemd te (mis)lukken. Tien tips voor het effectief benutten van cliëntenraden in ziekenhuizen.

Macfarlane, J. et al. (1997). 'Influence of Patients' Expectations on Antibiotic Management of Acute Lower Respiratory Tract Illness in General Practice.

Questionnaire Study'. In: British Medical Journal 315, no. 7117, pp. 1211-1214.

Makaryus, A.N. \& E.A. Friedman. (2005). 'Patients' Understanding of Their Treatment Plans and Diagnosis at Discharge'. In: Mayo Clinic Proceedings 80 no. 8, pp. 991-994

National Health Service (NHS). (2013). Review Into the Quality of Care and Treatment Provided by 14 Hospital Trusts in England. Overview Report.

NHS. (2013). A Promise to Learn. A Commitment to Act Improving the Safety of Patients in England. The Berwick Report by the National Advisory Group on the Safety of Patients in England.
NIVEL. (2012). Kennisvraag. 5 patiëntenrechten uit het wetsvoorstel Wet cliëntenrechten zorg anno 2012. Utrecht: NIVEL.

Nederlandse Patiënten Consumenten Federatie (NPCF). 'Standpunt zorgstelsel'. http://www.npcf.nl/index.php?option=com_aiportfolio\&view=article\&ltemid=2\& id $=83:$ Zorgstelsel\&standpunt $=4144$, voor het laatst geraadpleegd 5 september 2013

Onderzoeksraad voor Veiligheid. (2013). Veiligheid in Perspectief. Den Haag. OV.

Prins, Y. (2008). Ziekenhuis Survivalgids. Wegwijs in de wereld van de witte jassen. Schiedam: Scriptum.

Radley, A. \& M. Billig. (1996). 'Accounts of Health and Illness. Dilemmas and Representations'. In: Sociology of Health \& Illness 18, no. 2, pp. 220-240.

Raad voor Volksgezondheid en Zorg (RVZ). (2013). De participerende patiënt. Den Haag: RVZ.

RVZ (2010). De patiënt als sturende kracht. Den Haag: RVZ.

Smit. C. (2012). Een nieuwe horizon. De toekomst van de patiëntbeweging in Nederland. Hoogwoud: Kirjaboe.

Snelders, S. \& F. Meijman. (2009). De mondige patiënt. Historische kijk op een mythe. Amsterdam: Bert Bakker.

Sools, A. (2013). 'Narrative Health Research. Exploring Big and Small Stories as Analytical Tools'. In: Health: An Interdisciplinary Journal for the Social Study of Health, Illness and Medicine 17, no. 1, pp. 93-110.

Sools, A. (2010). De ontwikkeling van narratieve competentie. Bijdrage aan een onderzoeksmethodologie voor de bestudering van gezond leven. Den Haag: Albani.

Stevens, M. (2012). Patiëntenparticipatie. Een globaal overzicht van de mogelijkheden en beperkingen van verschillende vormen van patiëntenparticipatie in de ziekenhuiszorg. Den Haag: Rathenau Instituut. Stageopdracht.

Stichting Dutch Hospital Data (DHD). (2013). Kengetallen Nederlandse Ziekenhuizen. Utrecht: DHD (NFU en NVZ).

Struhkamp, R. (2004). Dealing with Disabilities. Inquiries from a Clinical Craft. Enschede: University of Twente. Thesis. 
Tsianakas, V. et al. (2012). 'Using Patients' Experiences to Identify Priorities for Quality Improvement in Breast Cancer Care. Patient Narratives, Surveys or Both?' In: BMC Health Services Research 12.

Ursum, J. et al. , Rijken, M., Heijmans, M., Cardol, M. \& Schellevis, M. (2011). Overzichtsstudies. Zorg voor chronisch zieken. Organisatie van zorg, zelfmanagement, zelfredzaamheid en participatie. Utrecht: NIVEL.

Verberne, W. (2013). Paternalisme op maat is nooit wenselijk. Masterthesis.

Verberne, W. (2013). Sterke positie van de patiënt: artsen vol hoop of huiver? Literatuuronderzoek naar het artsenperspectief over de veranderende positie van de patiënt van 2005-2013. Den Haag: Rathenau Instituut. Stageopdracht.

Voet, G.W. van der. (2005). De kwaliteit van de WMCZ als medezeggenschapswet. Den Haag: Boom Juridische Uitgevers. Thesis.

Vlaams Instituut voor Wetenschappelijk en Technologisch Aspectenonderzoek (viWTA). (2006). Participatieve Methoden. Een gids voor gebruikers. Brussel: ViWTA.

Ministerie van Volksgezondheid, Welzijn en Sport (VWS) (2011). Invulling subsidietaakstellingen VWS. Den Haag: VWS.

Ministerie van VWS. (2013). Gezamelijke agenda VWS 'van systemen naar mensen'. Den Haag: VWS

Werkgroep wenkend perspectief (2009). De kracht van diversiteit. Rapportage werkgroep wenkend perspectief. Haarlem.

Willemsen, R., E. Stolper \& Y. van Leeuwen. (2013). 'Twijfelen aan diagnose is goed'. In: Medisch Contact 68, nr. 24, pp.1304-1307.

Wetenschappelijke Raad voor het Regeringsbeleid (WRR). (2002). De toekomst van de nationale rechtsstaat. Den Haag: WRR.

'Zichtbare Zorg'. http://www.zichtbarezorg.nl/page/Programma-Zichtbare-Zorg/ Bruidsschat, voor het laatste geraadpleegd op vrijdag 24 mei 2013.

ZonMw (2000). Evaluatie wet medezeggenschap cliënten zorginstellingen (WMCZ). Den Haag: ZonMw.

ZonMw (2003). Visiedocument ZonMw-programmacommissie Vraagsturing. Den Haag: ZonMw.

\section{Dankwoord}

Dit rapport is tot stand gekomen dankzij de inspanningen van velen. Het was zeker niet eenvoudig om een gevoelig onderwerp als de rol van patiënten in ziekenhuiszorg op te pakken en te onderzoeken met behulp van een narratieve methode. We willen op deze plek iedereen bedanken die ons heeft geholpen met het onderzoek en heeft willen meedenken met de lijn van het verhaal en de hoofdboodschappen.

We bedanken allereerst onze mede-auteurs Anneke Sools, Lisa van Duijvenbooden, Stans Drossaert en Frans Brom, voor de liefdevolle aandacht voor de verhalen. Anneke Sools is vanaf de start van het project een zeer waardevolle sparringpartner geweest, zowel in het nadenken over de vormgeving van het onderzoek, als bij de uitvoering ervan en bij de analyse van de bevindingen. Liesbeth Jongkind leverde via de verslagen van de workshops met de zorgverleners zeer bruikbare inzichten voor het rapport. Pol Maclaine Pont en André Krom hebben als externe lezers het rapport van waardevol commentaar voorzien. We bedanken Rob Houtepen voor de waardevolle opmerkingen over de conceptualisering van het begrip 'patiënt'. Met al deze mensen hebben we vele waardevolle uren gepraat over de betekenis van ervaringen die mensen opdoen in het ziekenhuis, waarbij ook de eigen ervaringen niet onbesproken bleven.

We bedanken alle mensen die de moeite hebben genomen om hun ervaring met ziekenhuiszorg met ons te delen. De verhalen waren intiem, ontroerend en soms zelfs aangrijpend, en vormden stuk voor stuk een belangrijke motivatie om tot een goed rapport te komen.

Het rapport is mede tot stand gekomen dankzij de medewerking van alle patiëntenverenigingen die actief op onze oproepen hebben gereageerd, en aandacht hebben geschonken aan ons project op hun website en in hun ledenbladen. Onze dank gaat uit naar de personen die actief hebben deelgenomen aan de workshops waarin we hebben gevraagd naar hun ervaringen met patiënten. Onze dank gaat daarnaast uit naar de Nederlandse ziekenhuizen waar wij ons project mochten promoten, evenals naar de artsen, verpleegkundigen, patiënten en patiëntvertegenwoordigers die hun schaarse tijd met ons wilden delen om hun mening te geven over patiëntenervaringen.

Tot slot willen we de ambassadeurs bedanken die zich hebben ingezet voor dit project. Zij dachten kritisch mee met de lijn van het verhaal en de hoofdboodschappen, en voorzagen ons - gevraagd en ongevraagd - van waardevolle adviezen: Coleta Platenkamp, Antoinette Vietsch, Jan Klein, Rob Oudkerk, Lucien Engelen en Arre Zuurmond.

Stans van Egmond

Marjolijn Heerings

Geert Munnichs 


\section{Over de auteurs}

Frans Brom is sinds mei 2007 hoofd Technology Assessment van het Rathenau Instituut. Sinds 1 april 2010 bekleedt hij aan de Universiteit Utrecht de Rathenau Instituutleerstoel Ethiek van Technology Assessment. Hij is ook voorzitter van de Adviescommissie Wetenschappelijke Integriteit van Wageningen Universiteit en Researchcentrum, voorzitter van de subcommissie Ethiek en Maatschappelijke Aspecten van de Commissie Genetische Modificatie (www.cogem.net) en voorzitter van Unilevers Central Research Ethics Advisory Group (CREAG). Frans studeerde ethiek aan de Katholieke Theologische Universiteit Amsterdam, met een bijvak rechtsfilosofie aan de Vrije Universiteit Amsterdam (kandidaats 1987, doctoraal 1990). Hij promoveerde in de wijsgerige ethiek aan de Universiteit Utrecht met het proefschrift Onherstelbaar verbeterd. Biotechnologie bij dieren als een moreel probleem. In zijn huidige onderzoek richt hij zich op de betekenis van wetenschappelijke en technologische ontwikkelingen voor de samenleving.

Lisa van Duijvenbooden werkte aan dit project als junior onderzoeker, verbonden aan het Levensverhalenlab van de Universiteit Twente. Tijdens haar studie culturele antropologie en ontwikkelingsstudies raakte zij geboeid door de rijkdom en kracht van levensverhalen en deed zij onderzoek naar migratieverhalen van Angolezen in Nederland. Vervolgens heeft zij zich aan de Universiteit voor Humanistiek verder verbreed en verdiept in de narratieve wetenschap en onderzoek gedaan naar de meerwaarde van een narratieve benadering in de GGZ. Momenteel werkt zij als humanistisch geestelijk begeleider bij GGzEindhoven waar het werken met verhalen van cliënten én werknemers centraal staat.

Stans Drossaert is universitair hoofddocent bij de afdeling Psychologie, Gezondheid \& Technologie van de Universiteit Twente. Na haar studie Gezondheidswetenschappen aan de Universiteit van Maastricht, is zij in 2002 gepromoveerd op het onderwerp Psychosociale aspecten van het bevolkingsonderzoek borstkanker. Tegenwoordig houdt zij zich in haar onderzoek bezig met de vraag hoe patiënten gesterkt kunnen worden in het omgaan met zorginstellingen en zorgverleners. Zij is in het bijzonder geïnteresseerd in de rol die (internet)technologie hierin speelt. Zo onderzocht zij o.a. hoe online lotgenotengroepen, online keuzehulpen en thuistoegang tot het eigen medisch dossier patiënten kunnen sterken ('empoweren') in het omgaan met ziekte en zorg.

Stans van Egmond is projectleider van het project Patiënten Weten Beter en senior onderzoeker gezondheidsvraagstukken en informatietechnologieën bij het Rathenau Instituut. Stans is sinds 2000 politicoloog en genderstudiekundige (UvA, 2000). Stans heeft ruim tien jaar ervaring met onderzoek in de zorgsector en met zorgbeleid. Ze is in 2010 gepromoveerd bij het Instituut voor Beleid en Management Gezondheidszorg (iBMG) op onderzoek naar de rol en totstandkoming van wetenschappelijke kennis in overheidsbeleid op het terrein van gezondheidszorg en gezondheidseconomie. Recente publicaties waaraan Stans heeft bijgedragen aan: Kennisklimaat - (on)macht van de wetenschap in het klimaatdebat (2011) en Voorgeprogrammeerd - hoe internet ons leven leidt (2012).

Marjolijn Heerings werkt sinds 2012 als junior onderzoeker bij het Rathenau Instituut. Marjolijn studeerde aan de Universiteit van Amsterdam, waar zij BSc Psychologie, een MSc Psychologie en een MSc Medische Antropologie \& Sociologie behaalde. Voordat zij aan de slag ging bij het Rathenau Instituut deed zij bij de UvA onderzoek naar de ervaringen van volwassenen met ADHD en naar actief burgerschap en bewonersinitiatieven in de Amsterdamse Wijkaanpak. Ook werkte zij voor GGZ inGeest. Als groepsbegeleider werkte zij in verschillende psychiatrische ziekenhuizen en als junior onderzoeker deed zij kwalitatief onderzoek naar de implementatie van een screening en stepped-care interventieprogramma gericht op depressiepreventie bij ouderen.

Geert Munnichs is coördinator Technology Assessment bij het Rathenau Instituut. Hij houdt zich bezig met uiteenlopende onderwerpen als biomedische ontwikkelingen, ICT, veiligheid en privacy, de toekomst van de stad en dierenwelzijn. Hij is vooral geïnteresseerd in de wisselwerking tussen technologische systemen, public concerns en politieke besluitvorming. Geert studeerde milieuhygiëne, filosofie en geschiedenis in Wageningen en is aan de Rijksuniversiteit Groningen gepromoveerd in de sociale en politieke filosofie. Geert heeft meegewerkt aan de publicaties Security of eGovernment Systems - Final Report (2013), Goed, beter betwist - Publieksonderzoek naar mensverbetering (2012), Databases - Over ICT-beloftes, informatiehonger en digitale autonomie (2010), Animal-based Welfare Monitoring (2009), en De obesogene samenleving (2007).

Anneke Sools is universitair docent aan de Universiteit Twente, waar zij tevens als onderzoeker verbonden is aan het Levensverhalenlab, het Nederlandse expertisecentrum op het gebied van narratieve psychologie en geestelijke gezondheid. Na haar studie cultuur- en godsdienstpsychologie aan de universiteit Nijmegen promoveerde zij met een proefschrift over narratief onderzoek en gezondheidsbevordering aan de Universiteit voor Humanistiek in Utrecht. In 2010 richtte zij samen met Floor Basten het Netwerk voor Narratief Onderzoek Nederland op. Sinds 2012 zit zij in de science committee van het Internationale Congres Narrative Matters. Haar huidige onderzoek richt zich op narratieve toekomstverbeelding en veerkracht. Daarnaast doet zij kwalitatief therapieprocesonderzoek op het gebied van e-mental-health-toepassingen. 


\section{Interviews}

Hieronder volgt een lijst met organisaties en mensen met wie wij hebben gesproken tijdens het vooronderzoek van het project en mensen en organisaties die geïnterviewd zijn in het kader van dit onderzoek.

\section{Gesprekspartners vooronderzoek}

\begin{tabular}{|c|c|c|c|c|}
\hline & Organisatie & Gesprekspartner & Functie & Door \\
\hline 1 & ZonMw & Mw W. Reijmerink & Senior beleidsadviseur & Stans van Egmond \\
\hline 2 & ZonMw & Mw. M. Slager & $\begin{array}{l}\text { Programmamanager } \\
\text { patiënten en } \\
\text { wetenschappelijk } \\
\text { onderzoek }\end{array}$ & $\begin{array}{l}\text { Stans van Egmond, } \\
\text { Geert Munnichs en } \\
\text { Marth Stevens }\end{array}$ \\
\hline 3 & ZonMw & Mw. G. Ten Haaft & $\begin{array}{l}\text { Programmamanager } \\
\text { systeeminterventies en } \\
\text { freelance journalist }\end{array}$ & Stans van Egmond \\
\hline 4 & $\begin{array}{l}\text { Nederlandse Federatie } \\
\text { van Kankerpatienten- } \\
\text { organisaties (NFK) }\end{array}$ & Mw. A. Bögels & Directeur & Stans van Egmond \\
\hline 5 & NFK & Mw. L. Maes & Beleidsmedewerker & Stans van Egmond \\
\hline 6 & PBLQ Zenc & Mw. B. Pluut & $\begin{array}{l}\text { Organisatieadviseur en } \\
\text { onderzoeker }\end{array}$ & Stans van Egmond \\
\hline 7 & $\begin{array}{l}\text { KI / Centrum } \\
\text { Klantervaring Zorg } \\
\text { (CKZ) }\end{array}$ & Mw. D. Delnoij & Directeur & Stans van Egmond \\
\hline 8 & $\begin{array}{l}\text { Instituut Beleid \& } \\
\text { Management } \\
\text { Gezondheidszorg } \\
\text { (iBMG) }\end{array}$ & $\begin{array}{l}\text { Mw. H. Van de } \\
\text { Bovenkamp } \\
\text { Mw. S. Adams } \\
\text { Mw. F. Vennik }\end{array}$ & Onderzoekers iBMG & Stans van Egmond \\
\hline 9 & $\begin{array}{l}\text { Nederlandse Patiënten } \\
\text { en Consumenten } \\
\text { Federatie (NPCF) }\end{array}$ & Mw. J. Baardman & Adjunct-directeur & $\begin{array}{l}\text { Geert Munnichs en } \\
\text { Stans van Egmond }\end{array}$ \\
\hline 10 & NPCF & Mw. H. Post & $\begin{array}{l}\text { Senior } \\
\text { beleidsmedewerker }\end{array}$ & $\begin{array}{l}\text { Marthe Stevens en } \\
\text { Stans van Egmond }\end{array}$ \\
\hline 11 & NFK & Mw. C. Hoogstraten & $\begin{array}{l}\begin{array}{l}\text { Projectleider Els } \\
\text { Borst- gesprekken }\end{array} \\
\end{array}$ & Stans van Egmond \\
\hline 12 & YP Coaching & Mw. Y. Prins & $\begin{array}{l}\text { organisatieadviseur en } \\
\text { auteur van het boek } \\
\text { Ziekenhuis survivalgids }\end{array}$ & $\begin{array}{l}\text { Stans van Egmond en } \\
\text { Marjolijn Heerings }\end{array}$ \\
\hline 13 & Ministerie van VWS & Mw. M. Braam & $\begin{array}{l}\text { Senior beleidsadviseur } \\
\text { bij de Directie Markt en } \\
\text { Consument }\end{array}$ & Marjolijn Heerings \\
\hline 14 & D66 & Mw. P. Dijkstra & Tweede Kamerlid D66 & $\begin{array}{l}\text { Stans van Egmond en } \\
\text { Marjolijn Heerings }\end{array}$ \\
\hline 15 & SP & $\begin{array}{l}\text { Mw. R. Leijten } \\
\text { Mw. H. Drost }\end{array}$ & $\begin{array}{l}\text { Tweede Kamerlid en } \\
\text { medewerker SP }\end{array}$ & $\begin{array}{l}\text { Stans van Egmond, } \\
\text { Marjolinn Heerings, } \\
\text { Geert Munnichs, mw. } \\
\text { Geesink }\end{array}$ \\
\hline 16 & $\mathrm{CU}$ & Mw. de Wit - in 't Veld & $\begin{array}{l}\text { Beleidsmedewerker } \\
\text { Tweede Kamerfractie } \\
\text { CU }\end{array}$ & $\begin{array}{l}\text { Stans van Egmond en } \\
\text { Marjolijn Heerings }\end{array}$ \\
\hline 17 & CDA & Mw. Bruins Slot & Tweede Kamerlid CDA & $\begin{array}{l}\text { Stans van Egmond en } \\
\text { Marjolijn Heerings }\end{array}$ \\
\hline 18 & $\begin{array}{l}\text { Onderzoeksraad voor } \\
\text { Veiligheid }\end{array}$ & Mw. A. Nelis & Research Manager & Stans van Egmond \\
\hline
\end{tabular}


Interviews Stakeholders

\begin{tabular}{|c|c|c|c|c|c|}
\hline & Organisatie & Geïnterviewde & Functie & Datum & Interviewer \\
\hline \multirow[t]{2}{*}{1} & \multirow{2}{*}{$\begin{array}{l}\text { Koninklijke } \\
\text { Nederlandsche } \\
\text { Maatschappij tot } \\
\text { bevordering der } \\
\text { Geneeskunst } \\
\text { (KNMG) }\end{array}$} & Dhr. G. van Dijk & Beleidsadviseur & \multirow[t]{2}{*}{ 19-3-2013 } & \multirow{2}{*}{\begin{tabular}{|l} 
Stans van Egmono \\
en Marjolijn \\
Heerings
\end{tabular}} \\
\hline & & Dhr. H. Willems & Beleidsadviseur & & \\
\hline \multirow[t]{2}{*}{2} & \multirow{2}{*}{\begin{tabular}{|l|} 
Nederlandse \\
Vereniging van \\
Ziekenhuizen \\
(NVZ)
\end{tabular}} & $\begin{array}{l}\text { Mevr. R. } \\
\text { Zondervan }\end{array}$ & $\begin{array}{l}\text { Beleidsadviseur } \\
\text { kwaliteit } \\
\text { ziekenhuizen }\end{array}$ & \multirow[t]{2}{*}{ 22-4-2013 } & \multirow[t]{2}{*}{$\begin{array}{l}\text { Stans van Egmono } \\
\text { en Marjolijn } \\
\text { Heerings }\end{array}$} \\
\hline & & Mevr. M. Terlingen & $\begin{array}{l}\text { Beleidsadviseur } \\
\text { kwaliteit } \\
\text { ziekenhuizen }\end{array}$ & & \\
\hline 3 & $\begin{array}{l}\text { Vereniging } \\
\text { Verpleegkundigen } \\
\text { en Verzorgenden } \\
\text { Nederland (V\&VN) }\end{array}$ & Mevr. R. Kieft & $\begin{array}{l}\text { Adviseur } \\
\text { Excellente zorg }\end{array}$ & 21-5-2013 & Marjolijn Heerings \\
\hline 4 & $\begin{array}{l}\text { De Orde van } \\
\text { Medisch } \\
\text { Specialisten (OMS) }\end{array}$ & Mevr. M. Bennema & $\begin{array}{l}\text { Senior adviseur } \\
\text { Raad Kwaliteit }\end{array}$ & $21-5-2013$ & $\begin{array}{l}\text { Stans van Egmono } \\
\text { en Marjolijn } \\
\text { Heerings }\end{array}$ \\
\hline 5 & $\begin{array}{l}\text { College voor } \\
\text { zorgverzzeringen } \\
\text { (CVZ) } \\
\text { kwaliteitsinstituut } \\
\text { (in oprichting) }\end{array}$ & $\begin{array}{l}\text { Dhr. A. } \\
\text { Nederkoorn }\end{array}$ & Adviseur & 21-5-2013 & $\begin{array}{l}\text { Stans van Egmono } \\
\text { en Marjolijn } \\
\text { Heerings }\end{array}$ \\
\hline 6 & $\begin{array}{l}\text { Chronisch Zieken } \\
\text { en Gehandicapten } \\
\text { Raad Nederland } \\
\text { (CG-Raad) }\end{array}$ & $\begin{array}{l}\text { Mevr. M. } \\
\text { Hempenius }\end{array}$ & $\begin{array}{l}\text { Belangen- } \\
\text { behartiger }\end{array}$ & 23-5-2013 & $\begin{array}{l}\text { Stans van Egmono } \\
\text { en Marjolijn } \\
\text { Heerings }\end{array}$ \\
\hline 7 & $\begin{array}{l}\text { Stichting } \\
\text { Kwaliteitsinstituut } \\
\text { voor de de } \\
\text { Gezondheidszorg } \\
\text { (CBO) }\end{array}$ & Mevr. I. Raats & Senior consultant & 28-5-2013 & Marjolijn Heerings \\
\hline
\end{tabular}

Interviews Patiëntenparticipatieprojecten

\begin{tabular}{|c|c|c|c|c|c|}
\hline & Organisatie & Geïnterviewde & Functie & Datum & Interviewer \\
\hline 1 & UMC St. Radboud & Mevr. C. Jansen & $\begin{array}{l}\text { Chief Listening } \\
\text { Officer }\end{array}$ & 24-4-2013 & Marjolijn Heerings \\
\hline 2 & $\begin{array}{l}\text { Academisch } \\
\text { Medisch Centrum } \\
\text { (AMC) }\end{array}$ & Dhr. R. Simons & $\begin{array}{l}\text { Verpleegkundig } \\
\text { bestuurder }\end{array}$ & 7-5-2013 & Marjolijn Heerings \\
\hline 3 & $\begin{array}{l}\text { St. Elisabeth } \\
\text { Ziekenhuis }\end{array}$ & Mevr. R. Arts & $\begin{array}{l}\begin{array}{l}\text { Zorggroep- } \\
\text { manager }\end{array} \\
\text { a }\end{array}$ & 16-5-2013 & Marjolijn Heerings \\
\hline 4 & $\begin{array}{l}\text { Unie van } \\
\text { Katholieke Bonden } \\
\text { Ouderen (Unie } \\
\text { KBO) } \\
\end{array}$ & Mevr. M. De Booys & $\begin{array}{l}\text { Projectleider } \\
\text { keurmerk } \\
\text { Seniorrriendelijk } \\
\text { Ziekenhuis } \\
\end{array}$ & 30-05-2013 & Marjolijn Heerings \\
\hline 5 & $\begin{array}{l}\text { VieCuri Medisch } \\
\text { Centrum }\end{array}$ & Dhr. A. Koster & Internist & 3-6-2013 & Marjolijn Heerings \\
\hline 6 & Stichting CCC & $\begin{array}{l}\text { Mevr. C. } \\
\text { Platenkamp }\end{array}$ & Initiatiefneemster & 6-7-2013 & Marjolijn Heerings \\
\hline 7 & NFK & $\begin{array}{l}\text { Mevr. C. } \\
\text { Hoogstraten }\end{array}$ & Projectleider & 7-6-2013 & Marjolijn Heerings \\
\hline 8 & Altuïtion & Dhr. E. Huizenga & Adviseur & 19-6-2013 & Marjolijn Heerings \\
\hline 9 & $\begin{array}{l}\text { Mul Spiegelbijeen- } \\
\text { komsten }\end{array}$ & Mevr. M. Mul & Eigenaar & $25-6-2013$ & Marjolijn Heerings \\
\hline 10 & $\begin{array}{l}\text { Sint Lucas Andreas } \\
\text { Ziekenhuis }\end{array}$ & $\begin{array}{l}\text { Mevr. P. Den } \\
\text { Hartog }\end{array}$ & $\begin{array}{l}\text { Verpleegkundig } \\
\text { specialist } \\
\text { hematologie / } \\
\text { oncologie }\end{array}$ & 23-7-2013 & Marjolijn Heerings \\
\hline 11 & $\begin{array}{l}\text { Vu Medisch } \\
\text { Centrum }\end{array}$ & Mevr. M. Visse & Onderzoeker & 24-10-2013 & Marjolijn Heerings \\
\hline
\end{tabular}

Workshops

\begin{tabular}{l|l|l|l}
\hline & Deelnemers & Datum & Gespreksleider \\
\hline 1 & Net afgestudeerde artsen & $23-05-2013$ & Geert Munnichs en Marjolijn Heerings \\
\hline 2 & Verpleegkundigen & $04-06-2013$ & Geert Munnichs en Marjolijn Heerings \\
\hline 3 & $\begin{array}{l}\text { Vertegenwoordigers } \\
\text { patiëntenorganisaties }\end{array}$ & $11-06-2013$ & Geert Munnichs en Marjolijn Heerings \\
\hline 4 & Ervaren artsen & $25-06-2013$ & Geert Munnichs en Marjolijn Heerings
\end{tabular}


Aanwezig tijdens de workshop met vertegenwoordigers van

patiëntenorganisaties

\begin{tabular}{c|l}
1 & Algemene Nederlandse Gehandicapten Organisatie (ANGO) \\
\hline 2 & Alzheimer Nederland \\
\hline 3 & De Hart \& Vaatgroep \\
\hline 4 & Freya \\
\hline 5 & Myeloproliferatieve Neoplasmata (MPN) Stichting \\
\hline 6 & Nederlandse Vereniging voor Lymepatienten (NVLP) \\
\hline 7 & Parkinson Vereniging \\
\hline
\end{tabular}

Ambassadeurs

\begin{tabular}{c|l|l}
\hline & Naam & Functie \\
\hline 1 & Dhr. L. Engelen & Directeur Radboud REshape \& Innovation Centre \\
\hline 2 & Dhr. J. Klein & Hoogleraar Veiligheid in de Zorg, medisch adviseur Achmea, anesthesioloog \\
\hline 3 & Dhr. R. Oudkerk & Lector Haagse Hogeschool \\
\hline 4 & Mevr. C. Platenkamp & Coördinator Stichting CCC Zorg \\
\hline 5 & Mevr. A. Vietsch & $\begin{array}{l}\text { Lid Raad van Toezicht MC Haaglanden en lid van de Nederlandse Vereniging } \\
\text { van Toezichthouders in de Zorg (NVTZ) }\end{array}$ \\
\hline 6 & Dhr. A. Zuurmond & $\begin{array}{l}\text { Gemeentelijke Ombudsman van Amsterdam en Omstreken, oprichter } \\
\text { Kafkabrigade, voormalig bestuurslid Rathenau Instituut }\end{array}$ \\
\hline
\end{tabular}


Wie was Rathenau?

Het Rathenau Instituut is genoemd naar professor dr. G.W. Rathenau

(1911-1989). Rathenau was achtereenvolgens hoogleraar experimentele

natuurkunde in Amsterdam, directeur van het natuurkundig laboratorium van Philips in Eindhoven en lid van de Wetenschappelijke Raad voor het Regeringsbeleid. Hij kreeg landelijke bekendheid als voorzitter van de

commissie die in 1978 de maatschappelijke gevolgen van de opkomst van micro-elektronica moest onderzoeken. Een van de aanbevelingen in het rapport was de wens te komen tot een systematische bestudering van de maatschappelijke betekenis van technologie. De activiteiten van Rathenau hebben ertoe bijgedragen dat in 1986 de Nederlandse Organisatie voor Technologisch Aspectenonderzoek (NOTA) werd opgericht. NOTA is op 2 juni 1994 omgedoopt in Rathenau Instituut. 
Patiënten vormen het hart van de zorg. Zij zien wat niemand anders ziet. Zij moeten leven met de consequenties van hun ziekte en behandeling. Juist daarom moeten patiënten mondig kunnen zijn. Ook de overheid doet een steeds groter beroep op de mondige patiënt in haar streven naar kwalitatief betere en betaalbare zorg. Ziekenhuizen zijn complexe, technologische en voor patiënten moeilijk te doorgronden organisaties. Dit vraagt om een nadere analyse van mondigheid: krijgen patiënten voldoende ruimte om mondig te zijn, om zelf beslissingen te nemen en invloed te hebben op de zorg in ziekenhuizen? Hoe reëel is het idee van die sterke en mondige ziekenhuispatiënt eigenlijk?

Het Rathenau Instituut constateert in 'Sterke verhalen uit het ziekenhuis' dat de mondige patiënt maar moeizaam een plek verovert in het ziekenhuis. Tegelijkertijd ervaren veel patiënten een noodzaak om meer regie te hebben over het eigen zorgproces. Dit rapport gaat in op de obstakels, zowel bij patiënten zelf als bij de ziekenhuisorganisaties, die mondigheid in de weg staan. De auteurs pleiten ervoor dat ziekenhuizen beter gaan luisteren naar patiënten, gaan leren van hun ervaringen en daardoor beter gaan inspelen op de wensen en behoeften van patiënten. Het rapport geeft handvatten hoe ziekenhuizen het leren van patiëntenverhalen en -ervaringen kunnen borgen in de organisatie.
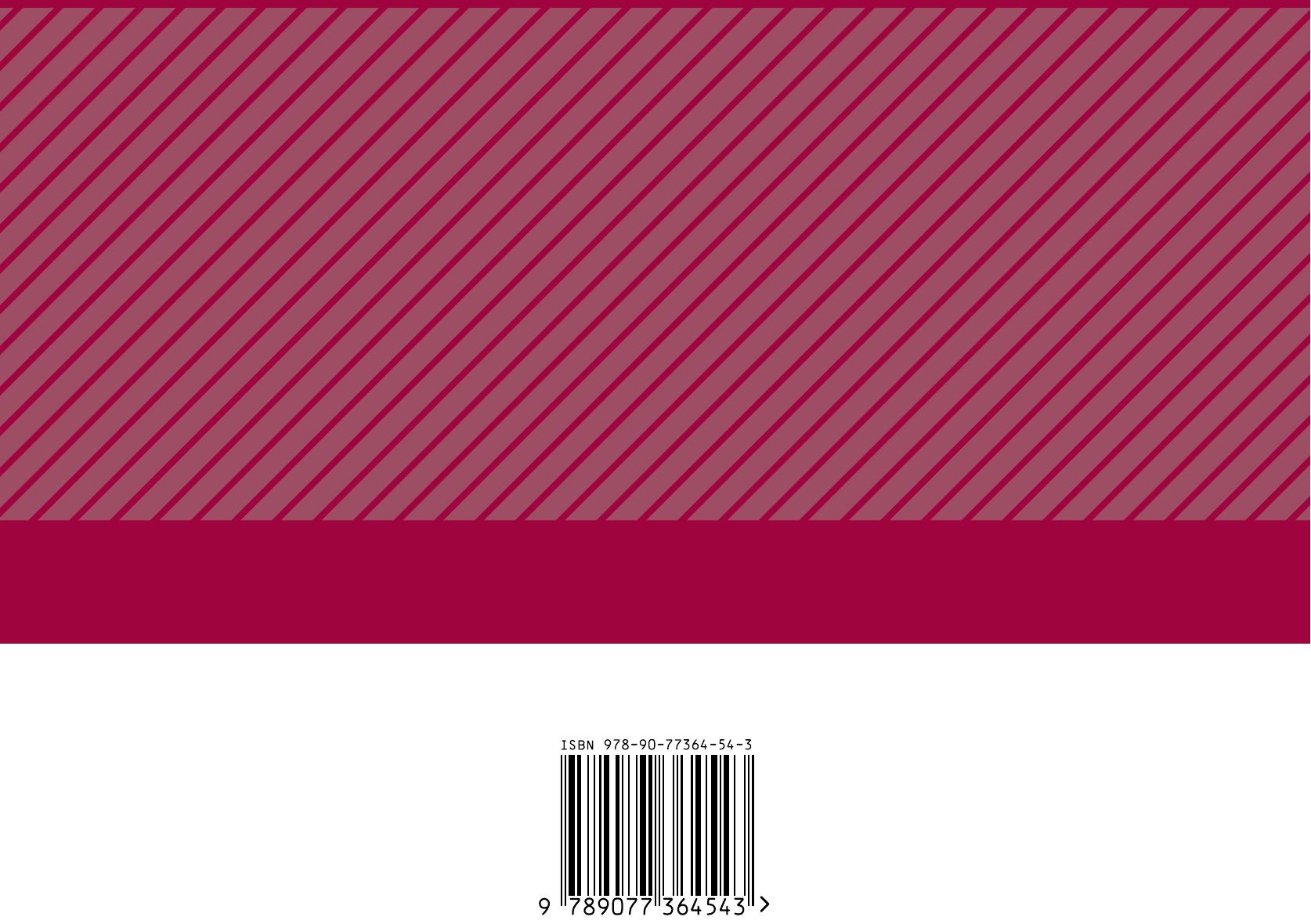